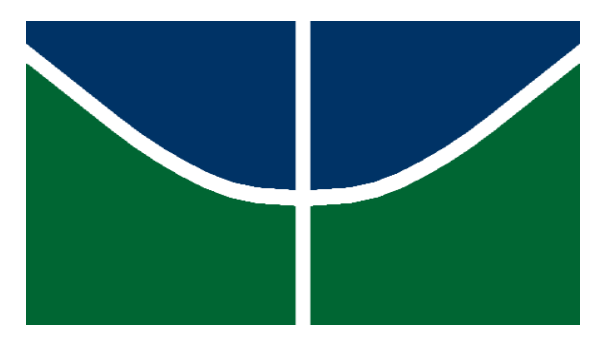

UNIVERSIDADE DE BRASÍLIA

INSTITUTO DE CIÊNCIAS BIOLÓGICAS

DEPARTAMENTO DE FITOPATOLOGIA

PROGRAMA DE PÓS-GRADUAÇÃO EM FITOPATOLOGIA

BUSCA DE FONTES DE RESISTÊNCIA GENÉTICA À VERTICILLIUM DAHLIAE EM SOLANUM MELONGENA, S. STRAMONIFOLIUM E S. SCUTICUM E MANEJO DA IRRIGAÇÃO PARA CONTROLE DA MURCHA DE VERTICÍLIO EM BERINJELA

RICARDO NUNES CABRAL

Brasília - DF

2015 
BUSCA DE FONTES DE RESISTÊNCIA GENÉTICA À VERTICILLIUM DAHLIAE NO GÊNERO SOLANUM E MANEJO DA IRRIGAÇÃO PARA O CONTROLE DA MURCHA DE VERTICÍLIO NA BERINJELA.

Dissertação apresentada à Universidade de Brasília como requisito parcial para obtenção do título de Mestre em Fitopatologia pelo Programa de Pós-Gradução em Fitopatologia.

\section{Orientador}

Adalberto Corrêa Café Filho, Ph.D.

BRASÍLIA

DISTRITO FEDERAL - BRASIL 


\section{FICHA CATALOGRÁGICA}

Cabral, Ricardo Nunes

Busca de fontes de resistência genética à Verticillium dahliae em Solanum melongena, S. stramonifolium e S. scuticum e manejo da irrigação para controle da murcha de verticílio em berinjela./ Ricardo Nunes Cabral.

Brasília, 2015. 92p.

Dissertação de mestrado. Programa de Pós-graduação em Fitopatologia. Universidade de Brasília, Brasília.

1. Solanum melongena, Verticillium dahliae, resistência genética vegetal, manejo da irrigação

I. Universidade de Brasília. PPG/FIT.

II. Busca de fontes de resistência genética à Verticillium dahliae no gênero Solanum e controle cultural baseado na irrigação da murcha de verticílio em berinjela. 
Dedico esta dissertação a toda minha família, especialmente aos meus pais, Rogéria de Fátima Rangel Nunes e José Carlos de Azevedo Cabral, à minha irmã, Renata Nunes Cabral e à minha namorada Lara Garcia Martos Nunes, pela participação, apoio, incentivo, compreensão, amor e por estarem sempre presentes em minha vida. Amo Vocês ! 


\section{AGRADECIMENTOS}

Ao meu professor orientador,

Prof. Dr. Adalberto Corrêa Café Filho pela confiança em mim depositada para a realização deste trabalho.

Aos Pesquisadores da Embrapa Hortaliças,

Dr. Ailton Reis e Dr. Leonardo da Silva Boiteux, pelo envolvimento no projeto e pela ajuda para realizá-lo, disponibilizando sementes do banco de germoplasma e acesso à coleção micológica.

Dr. Waldir Aparecido Marouelli, pela colaboração desde a montagem do experimento na Estação Experimental de Biologia da UnB até a finalização da parte escrita.

Aos Professores do Departamento de Fitopatologia da UnB,

Prof. Dr. Luiz Eduardo Bassay Blum e Prof. Dr. Cleber Furlanetto por aceitarem participar da Banca Examinadora desta dissertação.

Ao Professor da Universidade Federal de Viçosa,

Prof. Dr. Derly José Henriques da Silva por disponibilizar sementes do Banco de Germoplasma de Hortaliças da UFV e por aceitar participar da Banca Examinadora desta dissertação.

A todos os funcionários da Estação Experimental de Biologia da UnB,

Aldo, Evandro, Seu Fábio, Seu Chico e Dona Olinda pelo bom humor diário e por toda a ajuda que prestaram no desenvolvimento do experimento.

À aluna de graduação em Agronomia - UnB,

Julie Anne Lima, pelo interesse na participação neste projeto, facilitando o trabalho realizado no campo.

Aos Doutores,

Dr. Daniel Anacleto da Costa Lage e Dr. Frederick Mendes Aguiar, por terem ajudado nas análises da dissertação.

Aos estudantes do Programa de Pós-Graduação em Fitopatologia da UnB, pelo apoio e pelas amizades durante esses anos.

Aos professores e funcionários do Departamento de Fitopatologia - UnB, pelo conhecimento compartilhado.

A todos os funcionários da Embrapa Hortaliças.

À minha família e amigos por estarem sempre presentes nos momentos importantes da minha vida.

Ao CNPq e a FAP/DF pelo financiamento do presente projeto de pesquisa.

Muito Obrigado! Ricardo Nunes Cabral. 
Trabalho realizado junto ao Programa de Pós-graduação em Fitopatologia do Instituto de Ciências Biológicas da Universidade de Brasília, sob orientação do Professor Adalberto Corrêa Café Filho, com apoio do Conselho Nacional de Desenvolvimento Científico e Tecnológico (CNPq), da Coordenaçăo de Aperfeiçoamento de Pessoal de Nivel Superior (CAPES), do Centro Nacional de Pesquisas de Hortaliças (Embrapa Hortaliças) e da Fundaçăo de Apoio à Pesquisa do Distrito Federal (FAP/DF).

\title{
BUSCA DE FONTES DE RESISTÊNCIA GENÉTICA À VERTICILLIUM DAHLIAE EM SOLANUM MELONGENA, S. STRAMONIFOLIUM E S. SCUTICUM E MANEJO DA IRRIGAÇÃO PARA CONTROLE DA MURCHA DE VERTICILIO EM BERINJELA.
}

\author{
RICARDO NUNES CABRAL
}

DISSERTAÇÃO APROVADA em $\amalg$ OQ

$$
\text { Lviz Eduardo Bassay Blum }
$$

Prof. Luiz Eduardo Bassay Blum, Ph.D.

Examinador

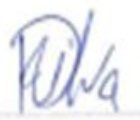

Prof. Derly José Henriques da Silva, D.Sc.

Examinador

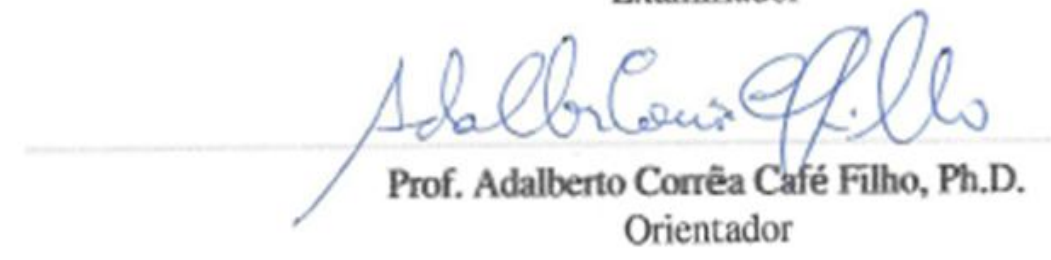

Orientador

$$
\begin{gathered}
\text { BRASÍLIA - DISTRITO FEDERAL } \\
\text { BRASIL }
\end{gathered}
$$




\section{SUMÁRIO}

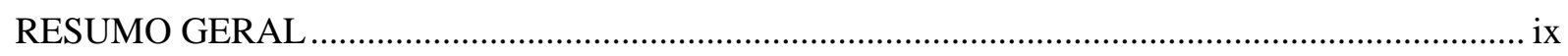

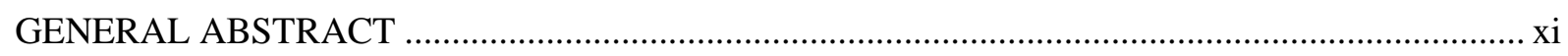

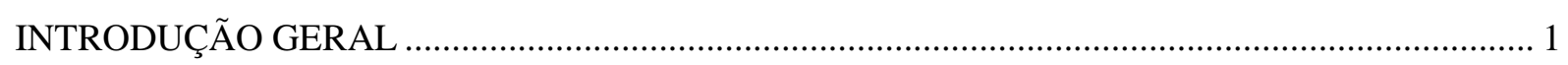

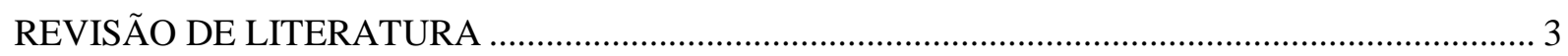

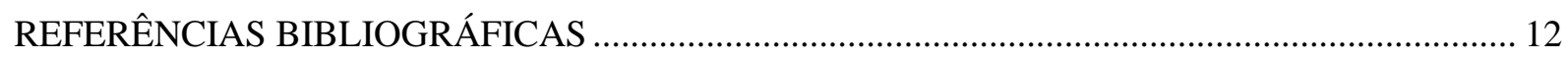

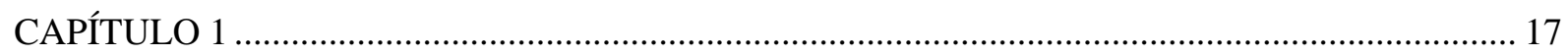

1. INTRODUÇÃO

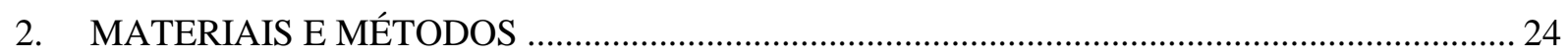

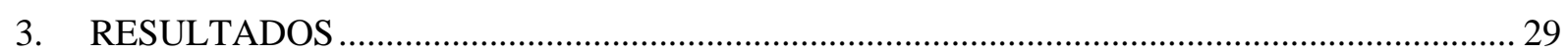

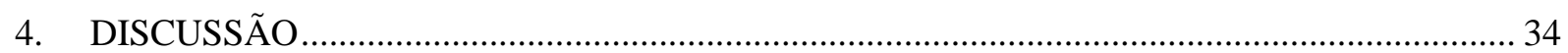

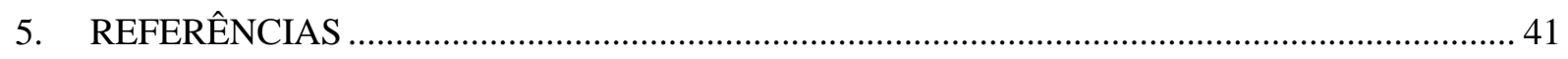

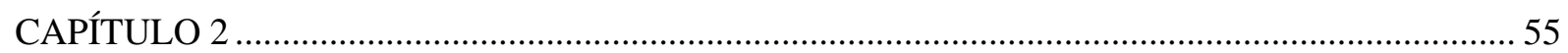

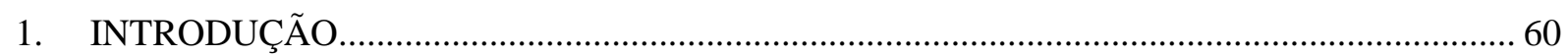

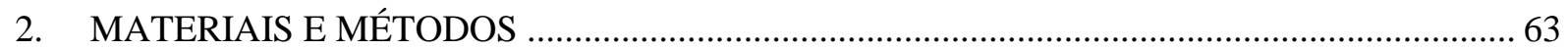

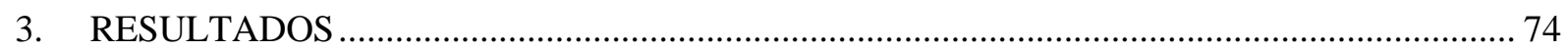

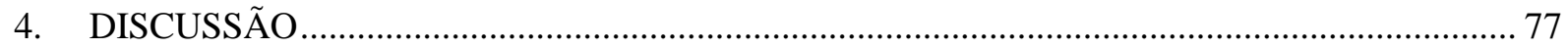

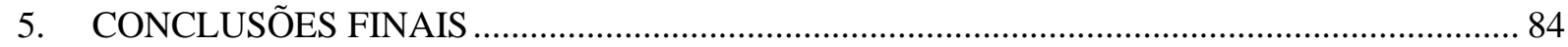

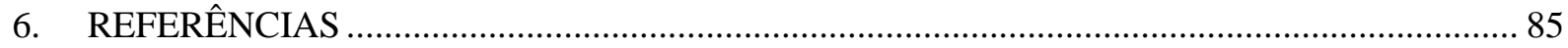




\section{LISTA DE TABELAS}

Tabela 1.1 - Isolados de Verticillium da coleção micológica do Laboratório de Fitopatologia do $\mathrm{CNPH}$.

Tabela 1.2 - Análise química do solo utilizado nos experimentos.

Tabela 1.3 - Genótipos de Solanum melongena submetidos à avaliação de resistência à Verticillium45

Tabela 1.4 - Genótipos do gênero Solanum utilizados na avaliação de resistência em Janeiro e Julho de 2014

Tabela 1.5 - Genótipos de Solanum scuticum e testemunha utilizados na avaliação de resistência .... 47

Tabela 1.6 - Reação de genótipos de Solanum melongena à mistura de "Vert. 15" e "Vert. 120" ....... 48

Tabela 1.7 - Índice de doença (\%) de genótipos de Solanum melongena aos isolados "Vert. 09"; "Vert. 15"; "Vert. 120" e "Vert. 02"

Tabela 1.8 - Efeito de diferentes isolados de Verticillium dahliae na altura de genótipos de Solanum melongena

Tabela 1.9 - Efeito de diferentes isolados de Verticillium dahliae na altura de genótipos de Solanum melongena . 50

Tabela 1.10 - Dados conjuntos da reação de Solanum stramonifolium à mistura de isolados "Vert. 15" e "Vert. 120". 51

Tabela 1.11 - Reação de genótipos de Solanum scuticum à mistura do isolado "Vert. 120" e "Vert. $15 "$.

Tabela 1.12 - Reação de genótipos de Solanum scuticum à mistura dos isolados "Vert. 120" e "Vert. $15 \%$

Tabela 2.1 - Volume de água (L) aplicado por irrigação em cada parcela experimental, conforme a água disponível no solo no momento da irrigação e a profundidade efetiva do sistema radicular da cultura. 88

Tabela 2.2 - Incidência de murcha de verticílio (\%) em plantas de berinjela, conforme a inoculação do solo (Inoc) com Verticillium dahliae e a porcentagem de água disponível no solo (AD) no momento da irrigação. 88

Tabela 2.3 - Severidade da murcha de verticílio (\%) em plantas de berinjela, conforme a inoculação do solo (Inoc) com Verticillium dahliae e a porcentagem de água disponível no solo (AD) no momento da irrigação 88

Tabela 2.4 - Altura de plantas de berinjela (m), conforme a inoculação do solo (Inoc) com Verticillium dahliae e a porcentagem de água disponível no solo (AD) no momento da irrigação...... 89

Tabela 2.5 - Altura de escurecimento do xilema de plantas de berinjela (m), provocada pela colonização de Verticillium dahliae, conforme a inoculação do solo (Inoc) com V. dahliae e a porcentagem de água disponível no solo (AD) no momento da irrigação

Tabela 2.6 - Porcentagem de escurecimento do xilema de plantas de berinjela, provocada pela colonização de Verticillium dahliae, conforme a inoculação do solo (Inoc) com $V$. dahliae e a porcentagem de água disponível no solo (AD) no momento da irrigação . 89 
Tabela 2.7 - Massa seca da parte aérea de plantas de berinjela (g) (exceto frutos), conforme a inoculação do solo (Inoc) com Verticillium dahliae e a porcentagem de água disponível no solo (AD) no momento da irrigação. 


\section{LISTA DE FIGURAS}

Figura 1.1 - Agressividade dos isolados de Verticillium a genótipos de Solanum melongena .....

Figura 2.1 - Temperatura máxima, média e mínima diária do solo ao longo do ciclo de cultivo da berinjela, avaliada a $0,05 \mathrm{~m}$ de profundidade. 91

Figura 2.2 - Temperatura máxima, média e mínima diária do ar ao longo do ciclo de cultivo da berinjela, avaliada a $0,30 \mathrm{~m}$ de altura junto às plantas . 91

Figura 2.3 - Umidade relativa máxima, média e mínima diária do ar ao longo do ciclo de cultivo da berinjela, avaliada a $0,30 \mathrm{~m}$ de altura junto às plantas 92 


\section{RESUMO}

A berinjela (Solanum melongena L.) éuma das hortaliças mais rústicas , porém,é suscetível a algumas doenças, principalmente fúngicas. A murcha de verticilio (Verticillium dahliae) é uma doença de manejo difícil, pois o controle curativo é impossível na prática e o preventivo nem sempre é eficaz, devido à capacidade de sobrevivência do patógeno no solo. Não há cultivares comerciais de berinjela resistentes ao Verticillium, o que torna atualmente inviável o controle por resistência genética. O manejo da disponibilidade de água no solo pode ajudar na redução da severidade da doença durante o ciclo da cultura,. Nesse contexto, o trabalho teve como objetivos a busca de fontes de resistência genética à $V$. dahliae em Solanum melongena, S. stramonifolium e S. scuticum e o manejo da água da irrigação para o controle da murcha de verticílio em berinjela. Foram testados genótipos de três espécies de Solanum quanto à resistência ao patógeno, em casa de vegetação, via inoculação pelo método de imersão de raízes em inóculo do patógeno $\left(2 \times 10^{6}\right.$ conídios/ml). A avaliação dos genótipos foi realizada 21 dias após a inoculação por uma escala de notas de 1 (planta assintomática) a 5 (planta morta), considerando sintomas foliares e escurecimento vascular. De acordo com a reação dos genótipos, estes foram classificados em resistentes ou suscetíveis, baseado no índice de doença (ID). Cerca de 35\%dos genótipos de S. melongena e 15\% dos genótipos de S. stramonifolium foram classificados como resistentes e demonstraram potencial para serem utilizados em futuros programas de melhoramento genético visando resistência à doença. Todavia, em S. scuticum, $100 \%$ dos genótipos foram classificados como suscetíveis. Em complemento, plantas de berinjela cv. Ciça foram transplantadas em microplots com volume de solo de $0,64 \mathrm{~m}^{3}$ e cobertura plástica, previamente infestados com $V$. dahliae ou sem o patógeno. Foram testados efeitos de quatro manejos de irrigação: $\mathrm{AD}_{90 \%}$ : irrigado quando a água disponível (AD) no solo fosse reduzida para 90\%, durante todo o ciclo da cultura; 
$\mathrm{AD}_{55 \%}$ : e $\mathrm{AD}_{20 \%}$ : irrigados quando a água disponível no solo fosse reduzida para $55 \%$ ou $20 \%$ durante todo o ciclo da cultura; e $\mathrm{AD}_{20-90 \%}$ : irrigado no estádio vegetativo com $20 \%$ de água disponível e $90 \%$ no estádio de produção. A incidência de doenças, foi de $72 \%$ em solo inoculado, não tendo sido afetada pela estratégia de manejo de água. Não houve efeito significativo dos fatores avaliados sobre a altura de plantas. Entretanto, no que se refere à severidade da doença, a estratégia de manejo adotada no tratamento $\mathrm{AD}_{20-90 \%}$ acarretou redução de $42 \%$ na severidade da doença, relativamente à média dos demais tratamentos, e menor altura da lesão provocada pelo patógeno no xilema, a qual não diferiu significativamente dos tratamentos $\mathrm{AD}_{55 \%}$ e $\mathrm{AD}_{20 \%}$. A produção de massa seca da parte aérea no tratamento $\mathrm{AD}_{20-90 \%}$ não diferiu dos demais e a produção no $\mathrm{AD} 90 \%$ superior que a dos $\mathrm{AD}_{55 \%}$ e $\mathrm{AD}_{20 \%}$, tanto em condições de solo inoculado quanto sem inoculação. A estratégia de manejo que se mostrou mais viável para reduzir a severidade da murcha de verticílio, sem prejudicar a produção de massa seca, foi irrigar com déficit durante o estádio vegetativo e de forma plena durante o estádio de produção. 


\section{GENERAL}

The eggplant (Solanum melongena L.) is considered a rustic crop however is susceptible to some fungi diseases. Verticillium wilt (Verticillium dahliae) is difficult to control, the curative control is impossible in the field, while the preventive one is not always effective, because of the extensive survival capacity of the pathogen. There are no commercial eggplant varieties resistant to the disease, so the genetic resistance control is ineffective. The irrigation management can be helpful in reducing the disease severity during the crop cycle, but the literature presents controversial studies about the amount of water that encourage the disease. In that context, the aim of the study was to seek sources of resistance to V. dahliae in Solanum genus accessions and to evaluate the relationship between water availability in the soil and occurrence of Verticillium wilt in eggplant, in order to identify irrigation strategies that do not favor the pathogen and slow the progress of the diseaseAccession of three species of genus Solanum were evaluated as to the reaction to $V$. dahliae, using the method of root immersion for inoculation, and transplanted to $1.5 \mathrm{~L}$ pots, kept in greenhouse of National Center for Research on Vegetables - CNPH, Brasília - DF, Brazil. The evaluations were carried out 21 days after the inoculation using scale of 1 (healthy plant) to 5 (dead plant). Based on a disease index (ID) for severity values, the accessions were classified as resistant or susceptible. $34.6 \%$ of S. melongena genotypes and $15.4 \%$ of S. stramonifolium genotypes were classified as resistant, presenting potential for use in future breeding programs for resistance to the disease. S. scuticum presented $100 \%$ of susceptible genotypes. The experiment was carried out at the Experimental Station of Biology of University of Brasília, Federal District, Brazil. Eggplants, cultivar "Ciça" were transplanted into concrete tanks containing artificially inoculated soil with $V$. dahliae and non inoculated soil as control. The treatments consisted in irrigating the plants when the amount of available water in soil were 
reduced to $90 \%(\mathrm{AD} 90 \%) ; 55 \%(\mathrm{AD} 55 \%)$ and $20 \%(\mathrm{AD} 20 \%)$, throughout the crop cycle, and when the soil reached $20 \%$ during the vegetative stage and $90 \%$ during the production phase (AD20-90\%). The treatment $\mathrm{AD}_{20-90 \%}$ reduces in $42 \%$ the severity of the disease, compared with the average of the others treatments, and had shorter length of xylem injury caused by the pathogen, which was not significantly distinct of $\mathrm{AD}_{55 \%}$ and $\mathrm{AD} 20 \%$. The dry matter production of shoot (except fruitage) in treatment AD20\% did not differ from the others, but the production in treatment $\mathrm{AD} 90 \%$ was significantly higher than $\mathrm{AD} 55 \%$ and $\mathrm{AD}_{20 \%}$, in soil with and without inoculation. The incidence of the disease, absent in non-inoculated soil treatments, was not affected by irrigation treatments in inoculated soil. There was no significant effect of the evaluated factor on plant height. The most effective irrigation strategy to reduce Verticillium wilt, without decrease in dry matter production, was the $\mathrm{AD}_{20-90 \%}$ scheme, where water availability is reduced in vegetative phase and sufficiently provided in the reproductive phase. 


\section{INTRODUÇÃO GERAL}

A berinjela (Solanum melongena L.) é uma hortaliça semi-perene, porém cultivada no Brasil como anual. Seu fruto é bastante apreciado na culinária de praticamente todas as regiões do país (Reis \& Boiteux, 2006). Os maiores produtores mundiais desta hortaliça são a China e Índia.

Apesar de ser uma das espécies mais rústicas da família Solanaceae, a berinjela é atacada por doenças de diversas etiologias, com grandes potenciais destrutivos. As doenças causadoras de murchas têm grande importância, pois seu controle é bastante difícil e podem comprometer o solo por longo período de tempo. Neste contexto, destaca-se a murcha de verticílio, causada por Verticillium dahliae Kleb., um fungo polífago, causador de grandes prejuízos em todo o mundo. Os sintomas mais comuns relacionados à doença são a murcha da planta, amarelecimento e necrose foliar. As folhas apresentam típicas lesões em formato da letra "V", com o vértice virado para o centro da folha. No xilema ocorre escurecimento em função da colonização do patógeno (Kurozawa et al., 2005).

A utilização de genótipos resistentes seria a melhor alternativa (Lopes et al., 2005), porém não há cultivares comerciais de berinjela com resistência genética ao patógeno. Desta forma, a busca de fontes de resistência para o melhoramento deve continuar. O melhoramento genético vegetal busca fontes de resistência em espécies relacionadas, tanto cultivadas, quanto selvagens, para que assim, a futura incorporação do gene de interesse seja possível de forma mais simples.

Com as dificuldades encontradas no controle das doenças, especialmente doenças de solo, a integração do controle cultural entre as medidas de manejo é essencial. A interação entre o patógeno do solo e a quantidade de água disponível pode favorecer o 
desencadeamento da doença ao criar um ambiente favorável para o patógeno. O controle cultural, baseado na irrigação, pode exercer papel fundamental no retardo da infecção e no processo de colonização, interferindo no ciclo de vida do patógeno e, dentro de um manejo integrado de doenças, incluindo outros fatores como a rotação de cultura e solarização do solo pode ser eficaz contra a murcha de verticílio. Outras formas de controle a serem combinadas dentro de um sistema integrado e manejo desta doença, incluem a rotação de culturas e a solarização.

Dessa forma, o presente trabalho teve como objetivos: (i) buscar fontes de resistência à murcha de verticílio em acessos do gênero Solanum; (ii) investigar a relação entre a disponibilidade de água no solo e a severidade da murcha da murcha de verticílio na cultura da berinjela; (iii) identificar uma estratégia de manejo da água de irrigação capaz de desfavorecer o patógeno e retardar o progresso da doença. 


\section{REVISÃO DE LITERATURA}

\section{A Planta Berinjela}

A Berinjela, (Solanum melongena L.) pertence a uma família cosmopolita e com grande importância econômica, a Solanaceae, que possui aproximadamente 3000 espécies e 90 gêneros. Engloba tanto hortaliças utilizadas para alimentação como tomate (Solanum lycopersicum L.), batata (S. tuberosum L.), jiló (S. gilo Raddi), pimenta e pimentão (Capsicum spp.), como para outros fins como o tabaco (Nicotiana tabacum L.) (Ribeiro et al., 1998; Vorontsova \& Knapp, 2012). Berinjela é a cultura mais importante do gênero Solanum entre aquelas nativas do velho mundo. Foi domesticada na região que é seu centro primário de diversidade, conhecida como Indo-Birmânia, que compreende China, Tailândia, Índia, Laos, Mianmar, Vietnã, Laos e Camboja (Daunay \& Janick, 2007; Hurtado et al., 2012). Seus ancestrais são naturalmente distribuídos na África e estão em um complexo denominado “eggplant complex", tendo o S. incanum como a espécie mais importante relacionada à evolução do S. melongena (Hurtado et al., 2012; Weese \& Bohs, 2010). Os árabes e orientais são os maiores consumidores e produtores desta hortaliça, sendo que Índia e China respondem por $90 \%$ da produção mundial (FAO, 2010).

\section{Berinjela no Brasil}

No Brasil, essa cultura foi introduzida pelos colonizadores portugueses no século XVI (Ribeiro et al., 1998; Filgueira, 2003). Não há dados recentes sobre a produção brasileira total, que segundo o censo agropecuário do IBGE (2006), foi de 78.217 toneladas. O estado de São Paulo detém aproximadamente $58 \%$ da produção (IEA, 2006), seguido pelo Rio de Janeiro e Minas Gerais. O Distrito Federal (DF) produziu, no ano em questão, 1.400 toneladas. Em 2010 esse número não cresceu, porém a área passou de 49 ha colhidos, para 42 
ha, o que faz do DF o oitavo maior produtor nacional (EMATER-DF, 2006; EMATER-DF, 2010). A pesquisa científica com essa espécie no Brasil começou em 1937, no Instituto Agronômico de Campinas (IAC), com a introdução de sementes de alguns materiais comerciais. Em 1940, foram montados os primeiros ensaios para avaliação das variedades de berinjela recém-introduzidas. (Ribeiro et al., 1998)

\section{Características da Planta}

A planta é uma solanácea perene, cultivada como anual. É arbustiva, com caule semilenhoso e ereto, podendo chegar a $1,8 \mathrm{~m}$ de altura, dispensando, muitas vezes, o tutoramento. Apresenta ramificações laterais e raízes bem desenvolvidas, que podem atingir profundidade superior a $1 \mathrm{~m}$ (Ribeiro et al., 1998). É uma espécie diploide, com flores hermafroditas e autocompatíveis, se reproduzindo, preferencialmente, por autogamia (Sekara et al., 2007), porém em condições ambientais favoráveis, a presença de insetos polinizadores, como a abelha (Aphis mellifera L.), aumenta a taxa de polinização cruzada (Polvorente et al., 2005). As flores são solitárias ou ocorrem em inflorescências, apresentando cálices bem destacados e com espinhos. (Filgueira, 2003)

Em relação ao valor nutricional, o fruto é rico em fibras e compostos fenólicos, fatores importantes para o aprimoramento da dieta (Santos et al., 2002), principalmente para o controle de hipercolesterolemia e hiperglicemia (Derivi et. al., 2002; Gonçalves et. al., 2006; Kwon et. al., 2008).

\section{A Murcha de Verticílio e o Agente causal}

A Murcha de Verticílio é uma importante doença vascular que afeta muitas plantas cultivadas e ornamentais em todo o mundo, causando grandes prejuízos (Naik et al., 2008). É 
causado por ascomycetos do gênero Verticillium (Inderbitzin \& Subbarao, 2014). O gênero Verticillium foi estabelecido por Nees von Esenbeck em 1816 e desde então mais de 190 espécies foram descritas baseadas nas características morfológicas dos conidióforos e nas plantas hospedeiras (Watanabe, 2010; Inderbitzin et al., 2011). Com o desenvolvimento das técnicas moleculares foi confirmado que o gênero Verticillium era composto de alguns grupos de fungo com relações ecológicas distantes. Desta forma, alguns foram removidos deste gênero e dispostos em outros, que compreendiam fungos parasitas de nematóides, patógenos de insetos e fungos e fitopatógenos, levando a uma redução no gênero (Gams \& Zare, 2002). Esta revisão no gênero resultou no conceito de Verticillium sensu stricto, reduziu a apenas cinco espécies associadas a plantas e fitopatógenos, com a espécie tipo sendo Verticillium dahliae (Gams et al., 2005).Esta espécie é predominante no Brasil e a fitopatógena mais impotante do gênero, juntamente com o Verticillium albo-atrum (Reis et al., 2007). Verticillium pertence à família Plectosphaerellaceae, família sem posição filogenética definida dentro da subclasse Hypocreomycetidae, classe Sordariomycetes, filo Ascomycota (Index Fungorum, 2015). Sua reprodução é assexuada, sem fase sexual relatada (Milgroom et al., 2014). A capacidade de formar estruturas de resistência, microescleródios, é importante não só para a biologia do patógeno, como também na taxonomia, e são tradicionalmente usadas como primeira característica para identificação de espécies. $V$. dahliae e $V$. albo-atrum são espécies difíceis de serem diferenciadas (Reis et. al, 2007). Isaac (1949) forneceu evidências de que o primeiro é capaz de formar microescleródios, enquanto o segundo forma micélio de repouso de cor escura. Recentemente, Inderbitzin et al. (2011) baseados em análise filogenética, morfologia, comparação com material de herbário e literatura, estabeleceram uma base taxonômica para o gênero, compreendendo dez espécies, $V$. albo-atrum, $V$. tricorpus, V. zaregamsianum, V. isaacii, V. klebahnii, V. nubilum, V. dahliae, V. longisporum, $V$. alfalfae e $V$. nonalfalfae. Após caracterização morfológica de isolados coletados em todo o 
Brasil, Reis et al. (2007) concluíram que a espécie $V$. albo-atrum parece não ocorrer no país, sendo $V$. dahliae a única espécie presente, infectando berinjela, tomate, batata, morango (Fragaria vesca L.), quiabo [Abelmoschus esculentus (L.) Moench. (=Hibiscus esculentus L.)] e cacau (Theobroma cacao L.).

$V$. dahliae produz nos bordos das colônias, em meio de cultura, ramificações verticiladas, formando, no geral, três conidióforos eretos, septados e ramificados, ligados por um eixo principal, em cujas extremidades são formados conídios unicelulares hialinos (Watanabe, 2010). Nas hifas mais velhas formam-se microescleródios, de cor marrom-escura a preta, , que podem sobreviver no solo por muitos anos, mesmo na ausência do hospedeiro. Em condições de campo, o inóculo mantém-se no solo indefinidamente, pois é um fungo polífago, tendo como hospedeiras, além de solanáceas, outras famílias de plantas cultivadas e

daninhas (Kurozawa et al., 2005). O patógeno é favorecido por temperaturas entre 21 e $27^{\circ} \mathrm{C}$ e seu ciclo de vida é dividido nos estágios dormente, parasitário e saprófito. Em condições favoráveis, ocorre a germinação dos microescleródios no solo e a penetração direta ou por ferimentos das raízes pelo fungo, seguida da colonização de seu córtex e endoderme e o movimento para o xilema, colonizando o xilema do caule e folhas, havendo, assim, a expressão dos sintomas, morte do tecido do hospedeiro e formação das estruturas de resistência no solo (Schnathorst, 1981).

\section{Sintomatologia e Epidemiologia}

$V$. dahliae pode infectar a berinjela em qualquer fase do crescimento, manifestando sintomas em alguns ramos ou em toda a planta, com sintomas externos de murcha e amarelecimento das folhas, a partir do bordo em forma de "V" com o vértice voltado para a nervura principal, seguido da necrose do tecido. Os primeiros sintomas são observados em folhas mais velhas, devido à penetração do fungo pela raiz e movimento de colonização 
ascendente. As plantas jovens infectadas podem ficar atrofiadas, com folhas pequenas. A região do tecido vascular, seja da haste ou pecíolo, sofre alteração de cor para marrom a preta, observada através de corte longitudinal. O escurecimento é menos intenso quando se compara com o causado por outro patógeno vascular, Fusarium oxysporum f. sp. melongena. O fungo pode atingir, via colonização vascular, o interior dos frutos e a semente, que pode ser fonte de inóculo primário. É capaz de afetar o crescimento da planta e causar diminuição do tamanho dos frutos, reduzindo a produção (Kurozawa et al., 2005). Na murcha de verticílio, o patógeno completa apenas um ciclo de infecção durante o ciclo de cultivo da hospedeira; desta forma, plantas infectadas ainda jovens, não servirão como fonte de inóculo para infecções futuras dentro desta mesma safra. Doenças com essas características são chamadas de monocíclicas e o aumento do número de plantas doentes durante o ciclo da cultura ocorre em função do inóculo inicial, presente no solo (Bergamin Filho \& Amorim, 2005). É comum a ocorrência de plantas doentes em reboleiras (Kurozawa et al., 2005).

\section{Controle}

As medidas de controle devem, primeiramente, focar na redução do inóculo inicial. Práticas curativas não serão eficazes, já que, ao ser infectada, restabelecer a sanidade da planta não é possível. Medidas preventivas devem ser tomadas de forma integrada. Ao ser introduzido a uma determinada área, a erradicação do patógeno torna-se muito difícil, devido à capacidade de sobrevivência no solo, mesmo em condições adversas. O fungo pode permanecer por mais de catorze anos no solo (Subbarao et al., 2015). Desta forma, o princípio de controle baseado na exclusão, prevenção da entrada do patógeno em área ainda não infestada, através da utilização de sementes e mudas sadias, controle da qualidade e movimento da água de irrigação, tem muita importância, mesmo quando incompleta, devido à lenta disseminação do patógeno dentro do campo (Kimati et al., 2005). 
A solarização, para erradicar o patógeno e reduzir a infestação de microescleródios na lavoura, é uma alternativa dentro do manejo, e alguns trabalhos mostram bons resultados deste método contra o V. dahliae (Tamietti \& Valentino, 2001; Yildz \& Benlioglu, 2010). A eliminação de restos culturais e a rotação de cultura são realizados quando o patógeno está presente no local, mas a rotação pode ser ineficiente devido à capacidade de sobrevivência e à ampla gama de hospedeiros do fungo (Reis \& Boiteux, 2006). Quando a rotação for realizada, deve-se ter cuidado com a escolha da família botânica. Larkin et al. (2011), obtiveram redução de microescleródios no solo na rotação de cultura com algumas espécies da família Brassicaceae, mas pode ser necessário cultivo sucessivo e o resultado foi melhor quando foi feita fumigação do solo com metam-sódium. Njoroge \& Kabin, (2009), obtiveram redução na severidade da doença em morangueiro quando utilizaram a rotação com incorporação dos resíduos de brócolis pós-colheita.

\section{Controle pela Resistência Genética}

A resistência é a habilidade da planta em suprimir, retardar ou prevenir a entrada ou a subsequente atividade do patógeno em seus tecidos (Parlevliet, 1997). A estratégia de resistência genética da planta às doenças, quando possível, é muito eficaz e a principal defesa da planta contra os patógenos (Vale et al., 2001). O emprego de variedades resistentes representa um pilar dentre as estratégias utilizadas para o controle de doenças, por ser aplicável em largas áreas e possuir baixo impacto ambiental comparado ao uso de agrotóxicos (Camargo, 2005). Existem dois tipos de resistência, vertical e horizontal, a primeira caracteriza-se quando uma cultivar é resistente a algumas raças do patógeno, é de grande efeito, monogênica ou oligogência, enquanto a segunda é denominada não específica, sendo controlada por vários genes, que se complementam, conferindo um fator de maior estabilidade, sendo incompleta (Van Der Plank, 1968). 
Há disponível no mercado brasileiro mais de uma dezena de cultivares, entre híbridos e cultivares. Estas cultivares diferem entre si em produtividade, formato, coloração, brilho de frutos e resistência à doenças (Ribeiro et al., 1998). Destaca-se a cultivar híbrida "Ciça" desenvolvida pelo Centro Nacional de Pesquisa de Hortaliças (CNPH), lançada em 1991. Possui resistência à antracnose (Colletotrichum gloesporioides) e podridão de fomopsis (Phomopsis vexans) (Reifschneider et al., 1993) e ainda continua sendo cultivada e estudada (Maldaner et al., 2009). Para obtenção do material resistente, deve-se primeiramente identificar fontes de resistência em material de espécies relacionadas, para posteriormente tentar incorporar a característica de interesse ao cultivar. Na identificação das fontes, pode-se utilizar métodos de inoculação artificiais em condições controladas ou realizar o experimento em áreas com histórico de infecção, e a avaliação da severidade e/ou incidência da doença deve ser feita comparando-se com o comportamento da cultivar suscetível (Lima et al., 2005). Como materiais cultivados já passaram por um processo de melhoramento, eles são os primeiros acessos onde essas fontes são buscadas. O híbrido Ciça é resultado do cruzamento entre acessos "CNPH 006", derivado da cv. Campinas, resistente à antracnose, e "CNPH 110", linhagem obtida da cv. "Florida Market", resistente à Phomopsis. A fonte de resistência à antracnose foi fornecida pela Universidade Federal do Rio de Janeiro (UFRJ) (Reifschneider et al., 1993). Caso não sejam encontradas fontes de resistência entre os genótipos cultivados, deve-se recorrer às espécies selvagens. No tomateiro, a espécie selvagem Solanum lycopersicum var. cerasiformi, forneceu o gene $V e$, que confere resistência à raça 1 de $V$. dahliae (Arie et al., 2007). Alternativamente, se a transferência da resistência for inviável via cruzamento sexual, a fonte de resistência selvagem pode ser utilizada como porta-enxerto contra o inóculo presente no solo (King et al., 2008).

Culturas como tomate, algodão, batata, entre outras, já tiveram resistência descrita para a murcha de verticílio (Pegg \& Brady, 2002). Entre os principais objetivos do 
melhoramento genético da berinjela no mundo está a busca pela resistência a esta doença (Sekara et al., 2007). Estes programas de melhoramento têm selecionado genótipos de berinjela e acessos selvagens do gênero Solanum que apresentem bons níveis de tolerância ao patógeno (O’Brien, 1983; Bletsos et al,. 2004) para serem selecionados na busca de híbridos resistentes (Jarl et al., 1999; Liu et al., 2015) ou como porta-enxerto (Bletsos et al., 2003; Liu et al., 2009).

\section{Controle Cultural: Manejo da água de irrigação}

A irrigação é uma das práticas culturais com maior impacto na ocorrência de doenças de plantas. Tem especial importância para o cultivo de hortaliças, que normalmente exigem altos volumes de água durante o ciclo de produção. A frequência entre regas, a quantidade de água aplicada e a forma de irrigação interferem substancialmente na disseminação e sobrevivência de patógenos e no processo de colonização e infecção da hospedeira (Lopes et al., 2006). O manejo da água afeta a severidade de várias doenças foliares como septoriose e oídio (Lage et al., 2011; Cabral et al., 2013) e do solo, principalmente as provocadas por oomicetos, como Pythium e Phytophthora, que possuem zoósporos e se locomovem em água livre através de flagelos (Massola Junior, et al., 2005). Para patógenos vasculares o processo fisiológico que desencadeia o aparecimento da doença deve ser analisado em duas fases: na infecção, onde se espera que maior disponibilidade de água favoreça a doença, e após a colonização, onde a obstrução dos vasos dificulta a passagem de água (Schnathorst, 1981).

Porém a interação entre água e o Verticillium é complexa. Há relatos em que a incidência da doença, em couve-flor e alfafa, foi relacionada a solos mais úmidos (Xiao \& Subbarao, 2000; Jefferson \& Gossen, 2002). No entanto, Arbogast et al. (1999) relatam aumento da doença em batata com redução da lâmina de água e, ainda, especificamente para 
berinjela, Bletsos et al. (1999) concluíram que a frequência da irrigação afeta negativamente apenas o brilho e intensidade da cor dos frutos, não interferindo na severidade da doença.

Visto que não há disponibilidade de cultivares de berinjela resistentes e que a relação da planta com o Verticillium não está bem esclarecida, este trabalho busca gerar informações para: (i) buscar fontes de resistência ao Verticillium em acessos de Solanum; (ii) propor um manejo cultural adequado, baseado na irrigação, a fim de desfavorecer o patógeno e retardar o progresso da doença. 


\section{REFERÊNCIAS BIBLIOGRÁFICAS}

ARBOGAST, M.; POWELSON, M. L.; CAPPAERT, M. R.; WARTRUD, L. S. 1999. Response of six potato cultivars to amount of applied water and Verticillium dahliae. Phytopathology 89(9): 782-788.

ARIE, T.; TAKAHASHI, H.; KODAMA, M.; TERAOKA, T. 2007. Tomato as a model plant for plant-pathogen interactions. Plant Biotechnology 24: 135-147.

BLETSOS, F. A.; THANASSOULOPOULOS, C. C.; ROUPAKIAS, D. G. 2003. Effect of grafting on growth, yield, and verticillium wilt of eggplant. Hortscience 36(2): 183-186.

BLETSOS, F. A.; THANASSOULOPOULOS, C. C.; ROUPAKIAS, D. G. 1999. Water stress and verticillium wilt severity on eggplant (Solanum melongena). Journal of Phytopathology 147: 243-248.

BLETSOS, F. A.; STAVROPOULUOS, N. I.; PAPADOPOULOU, P. P.; ANTONOPOULOU, P. D. 2004. Evaluation of eggplant (Solanum melongena L.) germplasm for resistance to Verticillium wilt. Advances in Hoticultural Science 18(1): 33-37.

CABRAL, R. N.; MAROUELLI, W. A.; LAGE, D. A. C.; CAFÉ FILHO, A. C. 2013. Septoria leaf spot in organic tomatoes under diverse irrigation systems and water management strategies. Horticultura Brasileira 31(3): 392-400.

CAMARGO, L. E. A. 2005. CONTROLE GENÉTICO. P. 325-342. IN: AMORIM, L.; REZENDE, J. A. M.; BERGAMIN FILHO, A. Manual de Fitopatologia - volume 1 - Princípios e Conceitos. 4ed. Agronômica Ceres.

DAUNAY, M. C. \& JANICK, J. 2007. History and iconography of eggplant. Chronica Horticulturae 47(3): 16-22.

DERIVI, S. C. N.; MENDEZ, M. H. M.; FRANCISCONI, A. D.; SILVA, C. S. DA; CASTRO, A. F. DE; LUZ, D. P. 2002. Efeito hipoglicêmico de rações à base de berinjela (Solanum melongena, L.) em ratos. Ciência e Tecnologia de Alimentos 22(2): 164-169.

EMATER-DF. Informativo da produção agrícola do Distrito Federal. Ano/Safra 2005/2006. Disponível em: www.emater.df.gov.br. Acesso em: 15 de jan. 2015

EMATER-DF. Informativo da produção agrícola do Distrito Federal. Ano/Safra 2009/2010. Disponível em: www.emater.df.gov.br. Acesso em: 15 de jan. 2015.

FAO - FAO Statistics Division: Food and Agriculture Organization of the United Nations, 2010. Disponível em: www.faostat.fao.org. Acessado em: 14 de jan. 2015.

FILGUEIRA, F. A. R.; Cultura da berinjela. p. 312-320. IN: Filgueira, F. A. R. 2003. Solanáceas: agrotecnologia moderna na produção de tomate, batata, pimentão, pimenta, berinjela e jiló. 1ed. UFLA.

GAMS, W.; ZARE, R.; SUMMERBELL, R. C. 2005. Proposal to conserve the generic name Verticillium (anamorphic Ascomycetes) with a conserved type. Taxon 54(1): 179. 
GAMS, W. \& ZARE, R. 2002. New generic concepts in Verticillium sect. Prostata. Mycological Research 106: 130-131.

GONÇALVES, M. DA C. R.; DINIZ, M. DE F. F. M.; BORBA, J. D. C.; NUNES, X. P.; BARBOSAFILHO, J. M. 2006. Berinjela (Solanum melongena L.) - mito ou realidade no combate as dislipidemias? Revista Brasileira de Farmacognosia 16(2): 252-257.

HURTADO, M.; VILANOVA, S.; PLAZAS, M.; GRAMAZIO, P.; FONSEKA, H. H.; FONSEKA, R.; PROHENS, J. 2012. Diversity and relationships of eggplants from three geographically distant secondary centers of diversity. Plos One 7(7): e41748.

INDERBITZIN, P.; BOSTOK, R. M.; DAVIS, R. M.; USAMI, T.; PLATT, H. W.; SUBBARAO, K. V. 2011. Phylogenetics and taxonomy of the fungal vascular wilt pathogen Verticillium, with the descriptions of five new species. Plos One6(12): e28341.

INDERBITZIN, P. \& SUBBARAO K. V. 2014. Verticillium systematics and evolution: how confusion impedes verticillium wilt management and how to resolve it. Phytopathology 104(6): 564-574.

INDEX FUNGORUM. Disponível em www.indexfungorum.org/names/names.asp. Acesso em: 1 fev. 2015.

INSTITUTO BRASILEIRO DE GEOGRAFIA E ESTATÍSTICA (IBGE). Censo Agropecuário, 2006. Disponível em: www.ibge.gov.br. Acesso em: 23 jan. 2015.

INSTITUTO DE ECONOMIA AGRÍCOLA (IEA). Valor de produção dos principais produtos da agropecuária do estado de São Paulo, 2006. Disponível em: www.iea.sp.gov.br. Acesso em: 20 jan. 2015.

ISAAC, I. A comparative study of pathogenic isolates of Verticillium. 1949. Transactions of the British Mycological Society 32: 137-157.

JARL, C. I.; RIETVELD, E. M.; HAAS, J. M. 1999. Transfer of fungal tolerance through interspecific somatic hybridisation between Solanum melongena and S. torvum. Plant Cell Reports 18(9): 791-796.

JEFFERSON, P. G.; GOSSEN, B. D. 2002. Irrigation increases verticillium wilt incidence in a susceptible alfalfa cultivar. Plant Disease 86(6): 588-592.

KING, R. S.; DAVIS, A. R.; LIU, W.; LEVI, A. 2008. Grafting for disease resistance. HortScience 43(6): 1673-1676.

KIMATI, H.; BERGAMIN FILHO, A.; AMORIM, L. 2005. Princípios gerais de controle. P. 307324. IN: Amorim, L.; Rezende, J. A. M.; Bergamin Filho, A. Manual de Fitopatologia - volume 1 - Princípios e Conceitos. 4ed. Agronômica Ceres.

KOWN, Y. I.; APOSTOLIDIS, E.; SHETTY, E. 2008. In vitro studies of eggplant (Solanum melongena) phenolics as inhibitors of key enzymes relevant for type 2 diabetes and hypertension. Bioresource Technology 99(8): 2981-2988. 
KUROZAWA, C.; PAVAN, M.A.; KRAUSE-SAKATE, R. 2005. Doenças das Solanáceas. p. 589-596 IN: Kimati, H.; Amorim, L.; Rezende, J.A.M.; Bergamini Filho, A.; Camargo, L.E.A. Manual de Fitopatologia - volume 2 - Doenças de Plantas Cultivadas. 4ed. Agronômica Ceres.

LAGE, D. A. C.; CABRAL, R. N.; MAROUELLI, W. A.; CAFÉ FILHO, A. C. C. 2011. Métodos e manejo da irrigação para o controle de doenças no Brasil central: avanços para a cultura do tomateiro. p. 91-108. IN: Grupo de Estudos Avançados em Fitopatologia, GEAFIP. Avanços e perspectivas no manejo de doenças de plantas.

LARKIN, R. P.; HONEYCUTT, W.; OLANYA, O. M. 2011. Management of verticillium wilt of potato with disease-suppressive green manures and as affected by previous cropping history. Plant Disease 95(5): 568-576.

LIMA, G. S. A.; ASSUNÇÃO, I. P.; VALLE, L. A. C. 2005. Controle genético de doenças radiculares. IN: Micherref, S. J.; Andrade, D. E. G. T.; Menezes, M. Ecologia e manejo de patógenos radiculares em solos tropicais. UFRPE: 247-278.

LIU, J.; ZHENG, Z.; ZHOU, X.; FENG, C.; ZHUANG, Y. 2015. Improving the resistance of eggplant (Solanum melongena) to verticillium wilt using wild species Solanum linnaeanum. Euphytica 201: 463-469.

LIU, N.; ZHOU, B.; ZHAO, X.; LU, B.; LI, Y.; HAO, J. 2009. Grafting eggplant onto tomato rootstock to suppress verticillium dahliae infection: the effect of root exudates. HortScience 44(7): 2058-2062.

LOPES, C. A.; MAROUELLI, W. A.; CAFÉ FILHO, A. C. C. 2006. Associação da irrigação com doenças de hortaliças. Revisão Anual de Patologia de Plantas 14: 151-179.

MALDANER, C. I.; GUSE, F. I.; STRECK, N. A.; HELDWEIN, A. B.; LUCAS, D. D. P.; LOOSE, L. H. 2009. Phyllochron, leaf area, and fruit yield in eggplants grown with one and two stems per plant in plastic greenhouse. Ciência Rural 39(3): 671-677.

MASSOLA JUNIOR, N. S. \& KRUGNER, T. L. 2005. Fungos fitopatogênicos. p. 149-206. IN: Amorim, L.; Rezende, J. A. M.; Bergamin Filho, A. Manual de Fitopatologia - volume 1 Princípios e Conceitos. 4ed. Agronômica Ceres.

MILGROOM, M. G.; JIMÉNEZ-GASCO, M. DEL M.; OLIVARES-GARCIA, C.; DROTT, M. T.; JIMENÉZ-DÍAZ, R. M. 2014. Recombination between clonal lineages of the asexual fungus Verticillium dahliae detected by genotyping by sequencing. PloS One 9(9): e106740.

NAIK, M. K.; RANI, G. S. D.; PRASADI, R. D.; PATIL, M. B.; SEN, B. 2008. An over-view of soil borne plant pathogens. p. 1-33. IN: Advances In Soil Borne Plant Diseases. 1ed. New India Publishing Agency.

NJOROGE, S. M. C. \& KABIR, Z. 2009. Comparison of crop rotation for Verticillium wilt management and effect on Pythium species in conventional and organic strawberry production. Plant Disease 93(5): 519-527.

O’BRIEN, M. J. 1983. Evaluation of eggplant accessions and cultivars for resistance to verticillium wilt. Plant Disease 67(7): 763-764. 
PARLEVLIET, J. E. 1997. Present concepts in breeding for disease resistance. Fitopatologia Brasileira 22: 7-15. (Suplemento).

PEGG \& BRADY. 2002. Verticillium wilts. CABI Publishing.

POlVERENTE, M. R.; FONTES, D. C.; CARDOSO, A. I. I. 2005. Produção e qualidade de sementes de berinjela em função do horário de polinização manual. Bragantia 64(3). 467472.

REIFSCHNEIDER, F. J. B.; MADEIRA, M. C. B.; SILVA, C. 1993. Ciça: novo híbrido de berinjela resistente à antracnose e à podridão-de-fomopsis. Horticultura Brasileira 11(1): 57.

REIS, A.; BOITEUX, L.S. 2006. Círculo de hospedeiras de isolados de Verticillium dahliae obtidos de tomateiro, quiabeiro e morangueiro. Brasília: Embrapa Hortaliças. 16p. (Boletim de Pesquisa e Desenvolvimento 21).

REIS, A.; BOITEUX, L.S.; COSTA, H. 2007. Determinação de espécies e de raças de isolados de Verticillium oriundos de diferentes estados do Brasil. Brasília: Embrapa Hortaliças. 13p. (Boletim de Pesquisa e Desenvolvimento 31).

RIBEIRO, C. S. C. DA; BRUNE, S.; REIFSCHNEIDER, F. J. B. 1998. Cultivo da berinjela (Solanum melongena L.). Brasília: Embrapa-CNPH, 23p. (Embrapa Hortaliças, Instruções Técnicas, 15).

SCHNATHORST, W. C. 1981. Life cycle and epidemiology. p. 81-111. IN: Mace, M. E.; Bell, A. A.; Beckman, C. H. Fungal Wilt Diseases of Plants. 1ed. Academic Press.

SEKARA, A.; CEBULA, S.; KUNICK, E. 2007. Cultivated eggplants - origin, breeding objectives and genetic resources, a review. Folia Horticulturae 19(1): 97-114.

SUBBARAO, K. V.; SHORT, D. P.; SANDOYA, G.; VALLAD, G. E.; KOIKE, S. T.; XIAO, C. L.; WU, B. M.; GURUNG, S.; HAYES, R. J. 2015. Dynamics of Verticillium species microsclerotia in field soils in response to fumigation, cropping patterns, and flooding. Phytopathology 105(5): 635-645.

TAMETTI, G. \& VALENTINO, D. 2001. Soil solarization: A useful tool for control of verticillium wilt and weeds in eggplant crops under plastic in the Po Valley. Journal of Plant Pathology 83(3): 173-180.

VALE, F. X. R. DO; PARLEVLIET, J. E.; ZAMBOLIM, L. 2001. Concepts in plant disease resistance. Fitopatologia Brasileira 26(3): 577-589.

VAN DER PLANK, J. E. 1968. Disease Resistance in Plants. Academic Press.

VORONTSOVA, M. S.; KNAPP, S. 2012. A new species of Solanum (Solanaceae) from South Africa related to the cultivated eggplant. Phytokeys 8. 11p.

WATANABE, T. 2010. Pictorial Atlas of Soil and Seed Fungi: Morphologies and Cultured Fungi and Key to Species. CRC Press, USA. 426p.

WEESE, T. L.; BOHS, L. 2010. Eggplant origins: out of Africa, into the Orient. Taxon 59(1): 4956. 
XIAO, C. L. \& SUBBARAO, K. V. 2000. Effects of irrigation and Verticillium dahliae on cauliflower root and shoot growth dynamics. Phytopathology 90(9): 995-1004.

YILDZ, A. \& BENLIOGLU, S. 2010. Effects of soil solarization and some amendments to control verticillium wilt in established olive orchards. African Journal of Biotechnology 9(40): 66606665 . 


\section{CAPÍTULO 1}

BUSCA DE FONTES DE RESISTÊNCIA À VERTICILLIUM EM SOLANUM MELONGENA, S. STRAMONIFOLIM E S. SCUTICUM 


\section{RESUMO}

A murcha de verticílio (Verticillium dahliae) é uma das principais doenças das Solanaceae. A berinjela (Solanum melongena L.), apesar de ser uma das culturas mais rústicas desta família, é suscetível a esse patógeno vascular que pode causar sérios prejuízos à cultura. Além de ser um patógeno polífago, a capacidade de sobrevivência do $V$. dahliae no solo na forma de microescleródios, quando há ausência da hospedeira, torna seu controle muito difícil. Adicionalmente, não há cultivares comerciais de berinjela resistentes à doença. Assim, a identificação de fontes de resistência torna-se muito importante para futuros trabalhos de melhoramento genético. O objetivo deste trabalho foi identificar fontes de resistência à murcha de verticílio entre acessos do gênero Solanum. Foram avaliados 33 acessos da espécies S. melongena, 26 de S. stramonifolium e 50 de S.scuticum, provenientes do banco de germoplasma da Universidade Federal de Viçosa (UFV) e da Embrapa Hortaliças. Os genótipos foram semeados e mantidos em bandejas de 128 células, contendo substrato comercial, as plântulas atingirem dois pares de folhas verdadeiras - tamanho para transplante. As plântulas foram inoculadas com isolados agressivos, da coleção micológica da Embrapa Hortaliças, de $V$. dahliae, na concentração $2 \times 10^{6}$ conídios/mL, pelo método de imersão de raízes e posterior transplante em vasos de 1,5 L, com solo preparado e devidamente esterilizado. A avaliação da severidade da doença foi realizada 21 dias após a inoculação, usando escala de notas variando de 1 (planta assintomática) a 5 (planta morta). Baseado no índice de doença (ID) para valores finais de severidade, os acessos foram classificados em resistentes ou suscetíveis. $34,6 \%$ dos acessos avaliados da espécie S. melongena foram classificados como resistentes, em $44,4 \%$ destes foram identificadas resposta altamente resistente, que corresponde à ausência de sintomas da doença. 15,4\% dos acessos avaliados de S. stramonifolium foram classificados como resistentes, enquanto que $100 \%$ dos acessos de $S$. 
scuticum foram suscetíveis. Assim, verificou-se existir acessos de S. melongena e $S$. stramonifolium com potencial para serem utilizados em programas de melhoramento genético visando resistência à murcha de verticílio.

Palavras-chave: Solanum melongena, Solanum stramonifolium, Solanum scuticum, Verticillium dahliae, resistência genética vegetal 


\section{ABSTRACT}

Verticillium wilt, caused by Verticillium dahliae Kleb., is an important disease of the botanical family Solanaceae. The eggplant (Solanum melongena L.), generally considered a rustic crop of this family, is susceptible to this vascular pathogen which causes serious damage to the crop. In addition to the pathogen polyphagous nature, the extensive survival capacity of $V$. dahliae in soil, in form of microsclerotia, without the host in field, makes its control very difficult. For the eggplant, there are no commercial varieties resistant to the disease. Thus, the identification of sources of genetic resistance becomes very important for future breeding programs. The aim of this study was to seek source of resistance to $V$. dahliae in Solanum genus accessions. Were evaluated 33 accessions of the species S. melongena, 26 of S. stramonifolium and 50 of S. scuticum, obtained from the germplasm bank of the Universidade Federal de Viçosa - UFV and from the National Center for Research on Vegetables - CNPH, the last one located in Brasília - DF. The materials were seeded in 128 cell trays, containing substrate for vegetable production, until the stage of transplanting to pots - two true leaves. At this point, the seedling roots were dipped in a water suspension containing aggressive strain of $V$. dahliae, at the concentration of $2 \times 10^{6}$ conidia/mL, and transplanted into 1.5 L pots containing soil prepared and sterilized in CNPH. The severity of the disease evaluations were carried out 21 days after the inoculation, using scale of 1 (healthy plant) to 5 (dead plant). Based on disease index (ID) for severity values, the accessions were classified as resistant or susceptible. The specie S. melongena presented $34.6 \%$ of materials classified as resistant, and, amoung them, $44.4 \%$ of them had immune response, it means no symptoms of the disease. S. stramonifolium showed almost $15.4 \%$ of genotypes with resistant type response, while S. scuticum showed $100 \%$ of susceptible genotypes. S. melongena and S. stramonifolium presented potential for use in breeding programs for resistance to disease. 
Key words: Solanum melongena, Solanum stramonifolium, Solanum scuticum, Verticillium dahliae, plant breeding 


\section{INTRODUÇÃO}

A berinjela, (Solanum melongena L.) é a principal hortaliça do gênero Solanum nativa na Ásia. A China e Índia são os maiores consumidores, além de serem responsáveis por 90\% da produção mundial. No Brasil tem havido um crescimento no consumo da hortaliça, motivado por consumidores interessados em adquirir produtos mais saudáveis e fitoterápicos. Estudos recentes demonstraram o efeito benefício da sua ingestão no controle de hipercolesterolemia e hiperglicemia (e.g. Derivi et al., 2002; Gonçalves et al., 2006). O Distrito Federal é o oitavo maior produtor nacional na lista liderada por São Paulo, estado que detém quase $60 \%$ da produção (IEA, 2006; EMATER-DF, 2006). Apesar de ser uma das culturas mais rústicas da família Solanaceae, esta olerícola é suscetível a alguns patógenos fúngicos como Colletotrichum gloeosporioides, Aschochyta phaseolorum e Verticillium dahliae (Filgueira, 2003). Este último é o causador da murcha de verticilío, doença vascular que causa grandes prejuízos em todo o mundo (Naik et al., 2008).

O fungo tem capacidade de sobreviver no solo através de microescleródios formados em hifas maduras. Em meio de cultura produz conidióforos verticilados, eretos e septados que produzem, nas extremidades, conídios unicelulares e hialinos. Na presença do hospedeiro suscetível, o fungo penetra pela raiz e coloniza o xilema, causando murcha e amarelecimento foliar a partir do bordo em forma de "V", com vértice voltado pra nervura principal, em seguida o tecido é necrosado (Kurozawa et al., 2005). Plantas infectadas podem apresentar tamanho reduzido em relação às sadias, podendo chegar ao colapso (Reis et al., 2011). Sua disseminação ocorre por sementes e mudas contaminadas, equipamento e máquinas contaminados e água da irrigação ou da chuva. Como o patógeno tem uma ampla gama de hospedeiras, tanto cultivadas como silvestres, estas plantas e os restos culturais são fontes de inóculo que permanecem no solo (Agrios, 2005). 
Para que ocorra a doença é necessário além do patógeno virulento, o hospedeiro suscetível e ambiente favorável. Desta forma, para realizar o controle, é necessário que um vértice deste triângulo não esteja em sintonia com os outros. Em áreas infestadas, onde o patógeno está presente ou onde não é possível tornar o ambiente desfavorável ao patógeno, as estratégias que visam tornar a hospedeira tolerante ou resistente à doença são a única saída (Kurozawa et. al., 2005).

Neste contexto destaca-se a medida de controle baseada na resistência vertical, em que a resistência da planta ao patógeno não é influenciada por fatores externos, é completa, quando a planta possui gene que lhe confere a resistência. Quando possível, ela é o principal mecanismo de defesa da planta contra os patógenos (Vale et al., 2001). Quando este gene não está presente no material comercial, é possível introduzi-lo ou introgredi-lo a partir do cruzamento com espécies relacionadas, não comerciais e selvagens, obtendo um híbrido.

No melhoramento genético de vegetais vários casos de sucesso, onde materiais resistentes tornaram importantes doenças de grandes culturas e hortaliças em doenças secundárias e até irrelevantes, e, mesmo não sendo duradouro em alguns casos, são de extrema importância para os produtores. Utilizado em várias regiões brasileiras, o principal híbrido de berinjela que apresenta resistência à doença é o "Ciça", apresentando resistência à antracnose, causada por Colletotrichum gloeosporioides e à podridão causada por Phomopsis vexans. Entretanto, este material não apresenta resistência genética à murcha de verticílio. Atualmente, a resistência à Verticillium não está disponível em S. melongena e estudos buscando isto estão sendo realizados em todo o mundo (Sekara et al., 2007). O presente trabalho teve como objetivo buscar fontes de resistência à murcha de verticílio em acessos do gênero Solanum. 


\section{MATERIAIS E MÉTODOS}

\section{Produção de inóculo}

A produção de inóculo seguiu o protocolo adaptado de Miranda et al. (2010). Cada isolado foi cultivado em placas de Petri com meio BDA + tetraciclina (500 ppm) por sete dias. Após esse período, um disco de aproximadamente $1 \mathrm{~mm}$ do meio de diâmetro, com crescimento abundante de micélio, foi transferido para Erlenmeyers de $250 \mathrm{~mL}$ contendo 100 $\mathrm{mL}$ do meio líquido $\mathrm{BD}$ (batata + dextrose). O Erlenmeyer foi colocado no agitador automático por 15 dias à temperatura ambiente, para crescimento do fungo. Após este processo, filtrou-se a suspensão de esporo em gaze dupla e ajustou-se a concentração de inóculo, com auxílio do hemacitômetro, para $2 \times 10^{6}$ conídios/mL.

\section{Escolha do isolado}

Foram repicados em meio BDA + tetraciclina 19 isolados de Verticillium (Tabela 1.1) da coleção micológica do Laboratório de Fitopatologia do Centro Nacional de Pesquisa de Hortaliças (CNPH), Brasilia - DF. Preparou-se o inóculo dos 10 isolados com melhores esporulações. Estes foram inoculados em espécies e cultivares suscetíveis à doença, berinjela (Solanum melongena) cv. "Ciça", jiló (Solanum gilo) cv. "Tinguá” e tomate (Solanum lycopersicum) cv. "Bonny Best". Este teste de patogenicidade foi realizado em outubro de 2013, na casa de vegetação do CNPH, para identificação dos isolados mais agressivos, e selecionou-se os patótipos "Vert. 15", isolado de berinjela proveniente de Atibaia - SP, em 1997 e "Vert. 120", isolado de berinjela proveniente de Venda Nova - ES, em 2010.

\section{Método de inoculação}


Os acessos dos diferentes genótipos de Solanum spp. foram semeados em bandejas de isopor ou poliestireno, de 128 células, contendo substrato para produção de hortaliças e transplantados para vasos ao atingirem o ponto de transplantio: dois pares de folhas verdadeiras.

A inoculação foi feita mediante a retirada das mudas das bandejas, lavagem das raízes com água e corte da extremidade distal, aproximadamente $2 \mathrm{~cm}$, para facilitar a entrada do patógeno. Após o corte, as raízes foram imersas por um minuto na suspensão de conídios em Becker de $100 \mathrm{~mL}$, contendo $50 \mathrm{~mL}$ de suspensão, na concentração $2 \times 10^{6}$ conídios $/ \mathrm{mL}$. No tratamento testemunha, a imersão das raízes foi feita em água. Em seguida, as mudas foram transplantadas para vasos contendo $1,5 \mathrm{~L}$ de solo, classificado como Latossolo VermelhoAmarelo distrófico típico, fase cerrado, com textura argilosa (56\% argila; $37 \%$ silte; $7 \%$ areia) preparado e autoclavado no CNPH, com as características químicas definidas (Tabela 1.2), previamente irrigados até o ponto de escorrimento. Adicionalmente, foi acrescentado ao colo de cada plântula, $5 \mathrm{~mL}$ de suspensão de conídios. No dia do transplantio as plantas não foram irrigadas, para evitar perda do inóculo através da água. A partir do segundo dia, as irrigações foram retomadas duas vezes ao dia, nos períodos matutino e vespertino.

\section{Avaliação dos sintomas}

A avaliação dos sintomas foi feita sempre 21 dias após a inoculação. Foram observados os sintomas externos e o escurecimento vascular, verificado através do corte longitudinal no colo de cada planta. Foi utilizada a escala de notas adaptada de Miranda et al. (2010), onde as notas de 1 a 5 representam: (1) plantas sem sintomas; (2) plantas sem sintomas de murcha ou amarelecimento foliar, mas com leve escurecimento vascular; (3) planta com escurecimento vascular intenso e/ou com murcha ou amarelecimento foliar; (4) planta com murcha intensa, associada com amarelecimento, necrose foliar e seca de ramos e 
(5) planta morta ou apresentando abcisão foliar devido à doença. Posteriormente, as notas foram classificadas de 0 a 4 , de forma que os genótipos tiveram as mesmas notas descritas anteriormente, mas subtraído de 1. A partir deste arranjo, foi calculado o índice de doença,

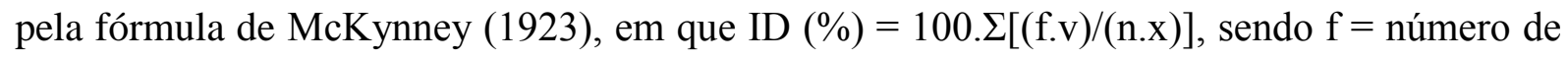
plantas com a mesma nota; $\mathrm{v}=$ nota observada; $\mathrm{n}=$ número total de plantas avaliadas $\mathrm{e} \mathrm{x}=$ nota máxima da escala. Foram classificados como resistentes acessos que apresentaram ID maior ou igual a $25 \%$ e não foram iguais estatisticamente a acessos com ID maior que este.

\section{Avaliação da resistência em acessos cultivados e silvestres de Solanum}

A avaliação da resistência nos acessos foi realizada em três espécies do gênero Solanum: (i) Solanum melongena; (ii) Solanum stramonifolium; (iii) Solanum scuticum. As duas últimas, espécies silvestres, têm sido estudadas como fontes de resistência para patógenos como Verticillium, Fusarium e Meloidogyne enterolobii (Miranda et al., 2010; Pereira et al., 2014; Pinheiro et al., 2014a; Pinheiro et al., 2014b) Para todos os experimentos, os tratamentos (genótipos) foram distribuídos em delineamento inteiramente casualizado e as notas de severidade da doença foram dadas individualmente para cada planta e foi calculado o índice de doença (ID) para cada repetição. Esses dados foram submetidos à análise de variância (ANOVA) e ao teste de agrupamentos de médias de Scott-Knott através do programa de análise estatística SisVar ver. 4.2 (Ferreira, 2003).

\section{Solanum melongena}

Os ensaios para avaliação da berinjela (S. melongena) foram realizados em duas etapas. Na primeira, em abril de 2014, foram inoculados, com suspensão de inóculo mista de esporos dos isolados Vert. 15 e Vert. 120, vinte materiais provenientes do banco de germoplasma da Universidade Federal de Viçosa - UFV e seis cultivares comerciais (Tabela 
1.3), que são conhecidamente suscetíveis e serviram como testemunha. A parcela experimental foi constituída por um vaso de 1,5 com três plantas, em três repetições.

$\mathrm{Na}$ segunda etapa, foram utilizados, separadamente, quatro isolados distintos (Vert. 09, Vert. 02, Vert. 120 e Vert. 15) para inocular oito acessos do banco de germoplasma do CNPH, originalmente pertencentes ao banco da UFV (Tabela 1.3). A parcela experimental foi constituída de quatro plantas, conduzidas em um mesmo vaso de 1,5 L, em três repetições, e adicionalmente uma repetição com testemunha não inoculada para cada genótipo. Este ensaio permitiu estimar a variabilidade dos isolados da coleção de Verticillium do CNPH quanto à agressividade. Neste ensaio, além do cálculo do ID, foi medida a altura dos genótipos em relação à respectiva testemunha. A altura da planta não inoculada foi medida e considerada como $100 \%$ de crescimento, a porcentagem da altura das inoculadas em relação aos controles não inoculados foi calculada para avaliação.

\section{Solanum stramonifolium}

Foram conduzidos dois experimentos sucessivos com a jurubeba vermelha $(S$. stramonifolium), em janeiro e julho de 2014. No primeiro foram inoculados, com combinação de Vert. 15 e Vert. 120, vinte e oito acessos do banco de germoplasma do CNPH (Tabela 1.4). A parcela experimental foi constituída por um vaso de 1,5 com três plantas, em três repetições e mais um vaso com três plantas não inoculadas para servirem de testemunha. Em julho, o experimento foi repetido visando revalidar os resultados encontrados, ainda em três repetições e três plantas por vaso, quando foram inoculados vinte e seis acessos da espécie (Tabela 1.4). Como testemunha suscetível dos ensaios, foram utilizadas a berinjela cv. Ciça, acessos de Berinjela 171 e 778 do CNPH, tomate cv. Ponderosa, e acessos S-43-1, S-43-5 e L-18-9 do CNPH. 


\section{Solanum scuticum}

Adicionalmente para a espécie $S$. scuticum, foram conduzidos dois ensaios, em maio e setembro de 2014. Em ambos a parcela experimental foi constituída por três plantas conduzidas em mesmo vaso de 1,5 L, porém o primeiro foi em quatro repetições, enquanto o segundo teve três. Foram avaliados cinquenta genótipos (Tabela 1.5), vinte e cinco em cada ensaio. Berinjela "Ciça" foi utilizada como testemunha suscetível. O inóculo utilizado neste experimento foi o composto pela mistura dos isolados Vert. 15 e Vert. 120. 


\section{RESULTADOS}

\section{Solanum melongena}

Todos os genótipos foram avaliados frente à mistura dos isolados "Vert. 15" e "Vert. 120" do patógeno, e, após cálculo do índice de doença, foram submetidos à análise estatística e classificados da seguinte forma: Altamente resistente, genótipos com ID igual a 0\%; Resistentes, genótipos com ID menor ou igual a 25\%, mas diferente estatisticamente dos genótipos com ID superior a 25\%; Suscetíveis, genótipos com ID superior a 25\%. Dos vinte e seis materiais, nove, apresentaram resistência, e destes, quatro foram classificados como altamente resistentes, “BGH 509”, "BGH 2637”, “BGH 907” e "BGH 5991”. Outros cinco genótipos foram classificados como resistentes, "BGH 312", "BGH 2605”, "BGH 4982", "BGH 2754" e "BGH 2404", com as respectivas porcentagens de ID, 5,5; 5,5; 8,3; 11,1; 11,1\%. Os outros dezessete genótipos foram classificados como suscetíveis, entre eles, os seis materiais comerciais avaliados. As suscetíveis foram separadas em três grupos distintos (teste Scott-Knott 5\%), o primeiro com porcentagens de ID entre 25 e $34 \%$ se agruparam "BGH 5992”, “BGH 909”, “BGH 906”, “BGH 2505” e o comercial "Shoya Long”. No segundo grupo, com ID entre 36\% e 53\% ficaram o "BGH 908", "Napoli”, "Embu”, "BGH 2755”, “Ciça” e "BGH 2447". Com maiores índices de doença, de 61\% a 75\% encontram-se o “Flórida Market”, “BGH 2756", “BGH 2541”, “Milan”, “BGH 2579” e "BGH 3350” (Tabela 1.6).

No segundo ensaio, foram realizadas inoculações separadamente com quatro diferentes isolados do patógeno, "Vert. 02", "Vert. 09", "Vert. 15" e "Vert. 120" estes isolados de $V$. dahliae possuem diferenças estatisticamente significativas quanto à agressividade. Comparando-se a agressividade dos isolados frente aos genótipos, o menos agressivo foi o "Vert. 09", que causou menor severidade da doença em todos os genótipos, 
com média total de ID 55,7\%. O "Vert. 02", com média de $84,1 \%$ de ID, foi o mais agressivo em todos os genótipos, exceto para o genótipo "CNPH 704", neste foi o "Vert. 120". Os "Vert. 120" e "Vert. 15" foram intermediários, com médias estatisticamente iguais de 75,2\% e 72,3\%, respectivamente, em metade dos genótipos eles apresentaram a mesma ID estatística. (Figura 1.1).

Oito genótipos foram avaliados e classificados como suscetíveis para todos os isolados. Apesar da suscetibilidade de todos, foram detectados quatro agrupamentos estatísticos, sendo o primeiro grupo com os materiais que obtiveram menores médias gerais de ID, que foram o "CNPH 721", o "CNPH 718” e o "CNPH 704", sendo o primeiro com 59,3\%, a menor média entre eles. Próximo grupo ficou apenas o "CNPH 705", com 70\%. “CNPH 690" e "Ciça" ficaram no terceiro grupo estatístico, até 75\% de ID e o "CNPH 694" e o CNPH 683” agrupados com as maiores médias, 82,8 e 86,4\% (Tabela 1.7).

Quando foi avaliada a altura das plantas em relação à testemunha não inoculada, as plantas inoculadas com o isolado mais agressivo, "Vert 02", também apresentaram as menores taxas de crescimento, em média, 49\% em relação ao controle, seguido do "Vert 120" com $62 \%$ de média. Em contrapartida, as plantas inoculadas com o isolado menos agressivo ("Vert. 09") foram as que mais cresceram, 71,4\% da testemunha. As plantas inoculadas com o "Vert. 15" apresentaram crescimento médio de $67 \%$ em relação à testemunha. Todos os isolados diferiram entre si para o teste Scott-Knott a 5\% (Tabela 1.8).

O "Vert 02 " foi o que mais afetou negativamente o crescimento de todos os genótipos. O "Vert. 09" o que menos afetou a maioria dos genótipos, excetuando-se o "Ciça" e o "CNPH 683", em que o "Vert. 15" foi o responsável pela altura abaixo do esperado. Apenas o genótipo "CNPH 704" quando inoculado com "Vert. 09" teve crescimento suficiente para não diferir estatisticamente da testemunha (Tabela 1.9). 
O genótipo “CNPH 683” esteve sempre no grupo dos que menos cresceram para todos os isolados, seguido do "CNPH 705" que só não aparece com essa condição na inoculação realizada com o "Vert. 09”. O genótipo “CNPH 704” e o “CNPH 690” foram agrupados entre os que mais cresceram para todos os isolado. A cv. Ciça apresentou crescimento de 51, 75, 65 e 77\%, respectivamente, em relação à altura da testemunha não inoculada frente aos isolados "Vert. 02", "Vert 09", "Vert 120 e "Vert 15" (Tabela 1.9).

\section{Solanum stramonifolium}

Como foram realizados dois experimentos com os genótipos de S. stramonifoloium, a classificação de resistência ou suscetibilidade foi realizada após a repetição do experimento e avaliação dos dados em conjunto.

No primeiro ensaio, dos trinta e três genótipos avaliados, formaram-se dois grupos estatísticos: o primeiro incluiu vinte e um genótipos com ID de 13,8 a 50\% e o restante, com ID de 58,3 a 94,4\%. No segundo grupo incluíram-se os cinco acessos usados como testemunha de agressividade do patógeno, como berinjela e tomate com informações prévias de que eram suscetíveis. O "CNPH 21", “CNPH 20" e "CNPH 120" com média inferior a 14\% e o "CNPH 114" e "CNPH 349" com média de 50\%, não diferiram estatisticamente. Sete genótipos da espécie não foram diferentes estatisticamente das testemunhas inoculadas (Tabela 1.10).

No experimento realizado em julho, os vinte e um acessos que obtiveram média até $50 \%$ no primeiro ensaio, acrescido de seis com média maior e a testemunha "Ciça" foram novamente avaliados. Neste caso formaram-se, novamente, dois grupos estatisticamente diferentes. Onze materiais ficaram no grupo com médias entre 45 e $89 \%$, entre eles a testemunha inoculada, "Ciça", cinco genótipos que no primeiro experimento haviam sido 
agrupados no grupo com média distinta das testemunhas, “CNPH 117”, “CNPH 19”, “CNPH 107”, “CNPH 111" e "CNPH 118”, e cinco mantiveram-se no grupo estatisticamente igual à testemunha em ambos os testes, "CNPH 108", "CNPH 108", “CNPH 115", “CNPH 121” e “CNPH 113”. Vinte e um genótipos, com médias de 22,2 a 44,4\% separaram-se estatisticamente da testemunha. A maior média foi da testemunha "Ciça", 88,8\% e a menor dos “CNPH 20" e "CNPH 22", com 22,2\% (Tabela 1.10).

Posteriormente, foi feita uma análise conjunta comparando os resultados dos dois experimentos. Neste caso, para os vinte e sete genótipos analisados, foram formados dez grupos estatisticamente distintos. Separado de todos, com maior média, ficou o padrão de suscetibilidade, a berinjela "Ciça". Quatro genótipos foram classificados como resistentes, divididos, igualmente, em dois grupos estatisticamente distintos, “CNPH 20", “CNPH 120”, "CNPH 336" e "CNPH 22", com média de ID respectivos de 18\%, 19,4\%, 22,2\% e 23,6\%. Outros vinte e três acessos foram classificados como suscetíveis, com média de ID entre $26,3 \%$ e $81,9 \%$. Os mesmos materiais avaliados em janeiro e julho apresentaram média total de ID estatisticamente diferente entre as épocas. Em janeiro esta média foi de 40,1\%, enquanto em julho de 42,9\%. O “CNPH 20" e o "CNPH 120" ficaram no grupo com menor média e distintos dos outros em ambas as épocas. A testemunha "Ciça" apresentou-se como muito suscetível em ambos os ensaios (Tabela 1.10).

\section{Solanum scuticum}

Após avaliação do ID, os genótipos foram classificados em resistentes ou suscetíveis para a mistura dos isolados, "Vert. 15" e "Vert. 120" do patógeno. Foram formados quatro grupos diferentes estatisticamente em relação ao ID, porém nenhum com resposta classificada como resistente. Três acessos foram agrupados junto à hospedeira suscetível, berinjela Ciça, com mais de $79 \%$ de ID, seis estiveram entre 56 e $71 \%$, nove formaram um conjunto entre 35 
e $46 \%$ e sete acessos apresentaram menores índices, entre 12 e 32\%, mas ainda classificados como suscetíveis, pelos critérios adotados neste trabalho (Tabela 1.11)

No segundo ensaio, vinte e cinco acessos, que não foram avaliados no primeiro ensaio, foram classificados de acordo com o ID calculado. Todos os acessos foram classificados como suscetíveis, neste caso, com dois agrupamentos, o primeiro com doze genótipos com ID de $36,1 \%$ a $58,3 \%$ e o segundo com treze genótipos e ID entre $61,1 \%$ e 88,8\% (Tabela 1.12). Em ambos, a cv. Ciça esteve entre as que apresentaram maiores ID, confirmando sua função de hospedeira suscetível para isolados de $V$. dahliae. Apesar de não apresentarem resistência completa, os materiais “CNPH 11”, “CNPH 52”, “CNPH 02”, “CNPH 13”, “CNPH 48”, “CNPH 51" e "CNPH 8" foram os que apresentaram menores ID, entre 12,5 e 31,2\%. Os que apresentaram os maiores foram "CNPH 58", "CNPH 18" e "CNPH 17" no primeiro e "CNPH 94”, “CNPH 103”, “CNPH 239”, estes do segundo experimento. Os sete genótipos do agrupamento estatístico de menor média no primeiro ensaio apresentaram ID menor que o “CNPH 87”, genótipo de menor ID no segundo ensaio. 


\section{DISCUSSÃO}

\section{Solanum melongena}

No ensaio com $S$. melongena e materiais comerciais tiveram quatro acessos, "BGH 309”, “BGH 907”, “BGH 2637” e "BGH 5991” com resposta altamente resistente, ou seja, não apresentaram sintomas da murcha de verticílio, o que não foi detectado nos testes com espécies selvagens. Além disso, cinco outros genótipos apresentaram ID entre 5\% e 11,2\%, todos esses provenientes do Banco de Germoplasma de Hortaliças da Universidade Federal de Viçosa (BGH-UFV). Assim, 65\% dos genótipos da UFV utilizados no teste foram classificados como resistentes. Essa porcentagem é bem maior que as encontradas nos materiais selvagens desse capítulo. O fato de alguns acessos apresentarem resposta altamente resistente indica que esses genótipos devem ser incluídos em futuros estudos para buscar a resistência vertical.

Outro ponto importante foi o resultado dos materiais comerciais. Assim como Bletsos et al. (2004) que relataram não haver resistência vertical para $V$. dahliae em acessos de $\mathrm{S}$. melongena do banco de germoplasma da Grécia, mas demonstraram diferentes graus de suscetibilidade entre os acessos, neste estudos todos foram classificados como suscetíveis com separação em três grupos estatisticamente distintos. Isso demonstra que níveis diferentes de resistência se encontram presentes em materiais que estão no mercado e são utilizados por produtores. O plantio de uma cultivar que apresenta maior nível de resistência ou tolerância, juntamente com a adoção de práticas de manejo integrado de doenças, pode ter efeito positivo na diminuição considerável de severidade final da doença e influenciar positivamente na produção (Vida et al., 2004). A cultivar "Flórida Market" esteve entre as maiores médias de ID. O’Brien (1983), inoculou vários acessos de S. melongena e dez cultivares com $V$. 
dahiliae, entre os cultivares, Flórida Market esteve entre as três que apresentaram maior intensidade da doença. Isto demonstra que a cultivar em questão tem alta suscetibilidade ao patógeno. Por outro lado, a cv. Shoya Long se diferenciou estatisticamente das comerciais, com menor média de ID entre elas.

O uso de materiais da mesma espécie no melhoramento favorece o uso da biotecnologia. O desenvolvimento de variedades resistentes em berinjela já teve o sucesso limitado pela incompatibilidade sexual com parentes silvestres (Kantharajah \& Golegaonkar, 2003). Collonier et al. (2001) relatam que a hibridização somática em berinjela para transferência de resistência, quando realizadas entre espécies pouco relacionadas a progênie pode ser estéril, enquanto em espécies intimamente relacionadas ocorre a produção de híbridos férteis, com traços da resistência adquirida e com a morfologia perto da berinjela cultivada, o que torna desnecessários uma série de retrocruzamentos para recuperar característica fenotípica da hortaliça cultivada. Em outro estudo, Basay et al., (2011) hibridizaram cultivares de berinjela suscetíveis com um cultivar que se apresentou tolerante em teste de campo, obtiveram uma progênie $F_{1}$ e com uma autofecundação a $F_{2}$, após testes de patogenicidade, concluíram que a geração $\mathrm{F}_{2}$ apresentou maior resistência em relação à anterior. Os autores ainda alcançaram resultados semelhantes de suscetibilidade e tolerância em cultivares por mais de um ano.

O número de sementes obtido do BGH-UFV não foi suficiente para a repetição do experimento, portanto, os genótipos apresentados devem ser avaliados novamente, para confirmação das boas fontes de resistência detectadas pelo resultado desses ensaios.

No ensaio com inoculação de quatro isolados de $V$. dahliae em oito genótipos de $S$. melongena, houve reação da espécie inoculada mesmo quando a hospedeira original do isolado foi o tomateiro (Tabela 1.1), demonstrando a natureza polífaga do patógeno (Reis \& 
Boiteux, 2006), assim como relataram Miranda et al. (2010) para a reação de tomateiro aos $V$. dahliae provenientes de quiabo e berinjela.

Foi claramente detectada variação na agressividade dos isolados, sendo aquele proveniente do tomate o mais agressivo e aquele coletado na Inglaterra, o menos. Os dois isolados da berinjela não se diferenciaram estatisticamente. A agressividade dos isolados foi diretamente relacionada com o crescimento das plântulas. As plantas que menos cresceram, em relação à testemunha, foram as inoculadas com o isolado mais agressivo, enquanto as plântulas que mais cresceram foram as inoculadas com o isolado menos agressivo. Os isolados intermediários para altura mantiveram a relação inversamente proporcional de agressividade e altura de planta. Este resultado equivale ao que obtiveram Lahkim-Tsor et al. (2001), em que isolados de $V$. dahliae de diferentes hospedeiros foram inoculados em batata e tomate e, para a batata, plantas que apresentaram maior severidade da doença, também apresentaram menor crescimento em relação à testemunha.

\section{Solanum stramonifolium}

O uso de genes de espécies selvagens que têm relação com espécies cultivadas para aumentar seu desempenho já é uma prática estabelecida nos programas de melhoramento genético vegetal, com sucesso por vários anos (Hajjar \& Hodgkin, 2007). Por exemplo, para a cultura do trigo (Triticum aestivum), Mcintosh (1995) relatou que dos mais de 47 genes de resistência à ferrugem (Puccinia recondita) mais de 22 eram originários de espécies diferentes de T. aestivum, incluindo 10 genes que foram registrados.

Desta forma, foram realizados os experimentos em S. stramonifolium. Quando foi realizada análise estatística agregando os ID dos acessos nas épocas distintas os vinte e sete genótipos utilizados separaram-se estatisticamente em dez grupos, sendo a testemunha 
diferente de todos os outros grupos, com a maior média de ID. Os acessos "CNPH 20" e "CNPH 120" tiveram média inferior a 20\% e o "CNPH 336" e "CNPH 22" média inferior a 24\%, e foram classificados como resistentes. Alguns destes já demonstraram resistência a outros patógenos de solo. Pinheiro et al. (2014b) classificou o "CNPH 20" e "CNPH 22" como resistentes à Meloidogyne enterolobii, mas não testaram os genótipos "CNPH 336" e “CNPH 120". O "CNPH 22" demonstrou resistência para F. oxysporum f. sp. lycopersici raça 3, assim como o "CNPH 120", em contrapartida, "CNPH 336" foi classificado como suscetível a este patógeno (Pereira et al., 2014). O acesso "CNPH 20" não foi avaliado por Pereira et al. (2014). Como não foi observada resposta altamente resistente para nenhum genótipo e o ensaio com o F. oxysporum f. sp. lycopersici (Pereira et al., 2014) também demonstrou níveis diferentes de resistência, a ocorrência da resistência quantitativa (horizontal) para diferentes patógenos de solo parece estar presente entre os genótipos de Solanum. Reforçando esta evidência, na comparação entre épocas, houve diferença estatística, apesar de pequena, entre a média de ID em janeiro e julho (Tabela 1.10). O segundo apresentando maior severidade para os mesmos acessos, mas os genótipos tenderam a se manter com a classificação igual. Isto pode explicado como efeito do ambiente na severidade da doença, uma das características da resistência horizontal (Parlevliet \& Zadoks, 1977). Porém, a temperatura média ambiente do $\mathrm{CNPH}$ fora da casa de vegetação foi de $25,5^{\circ} \mathrm{C}$ no primeiro mês do ano, enquanto no sétimo foi de $19,7^{\circ} \mathrm{C}$. Segundo Michereff et al. (2005) as condições ambientais favoráveis para murcha de verticílio são amenas; Kurozawa et al. (2005) descrevem temperatura de 22 a $26^{\circ} \mathrm{C}$ como ideais para o $V$. dahliae. Não é possível confirmar que a temperatura foi o fator responsável pelo aumento da severidade nos genótipos, embora a diferença entre as temperaturas entre os ensaios tenham sido expressivas.

A identificação e a utilização da resistência horizontal em programas de melhoramento encontram limitações devido à dificuldade na avaliação fenotípica e da incorporação desta 
resistência nestes programas (Martiello et al., 1997). Porém há a possibilidade de utilizar o $S$. stamonifolium como porta-enxerto para espécies cultivadas de solanáceas, como tomate e berinjela. Tomateiro enxertado com esta espécie apresentou maior produtividade, quando comparado aos tomateiros autoenxertados, que pereceram devido à murcha-bacteriana (Ralstonia solanacearum) na região amazônica (Farias et al., 2013). Simões et al. (2014), demonstraram que para tomateiro há compatibilidade de enxertia com S. stramonifolium. São necessários estudos para demonstrar compatibilidade entre essa espécie e a berinjela. Espécies de Solanum selvagens já foram evidenciadas com capacidade de enxertia (Bletsos et al., 2003), de hibridização interespecífica (Liu et al., 2015) e de hibridização somática com $S$. melongena (Collonier et al., 2003) para conferir resistência a diferentes patógenos. Desta forma, existe a possibilidade de utilização da espécie $S$. stramonifolium, como fonte de resistência, tanto em programa de melhoramento quanto como porta-enxerto..

Estudos confirmatórios com genótipos que demonstraram alta resistência nos ensaios, devem ser repetidos e expandidos, com a utilização dos outros materiais, incluindo os demais genótipos classificados como resistentes ao nematoide das galhas por Pinheiros et al. (2014a), e, desta forma, ampliar as informações sobre os níveis de resistência da espécie e fatores que influenciam essa expressão.

\section{Solanum scuticum}

A primeira etapa do melhoramento genético vegetal envolve a identificação de genes e/ou características de interesse em germoplasma exótico ou em populações que não foram submetidas a qualquer processo de melhoramento, como parentes silvestres, e sua posterior incorporação em materiais de interesse, agronomicamente adaptados (Nass \& Paterniani, 2000). 
Em um dos poucos estudos de melhoramento de Solanaceae com Solanum scuticum, Pinheiro et al. (2014a) classificaram quinze materiais resistentes ao nematoide causador de galhas Meloidogyne enterolobii. Destes, cinco foram utilizados no presente estudo de resistência para Verticillium. Três desses materiais, "CNPH 48”, "CNPH 51" e "CNPH 52", que foram anteriormente classificados como resistentes para $M$. enterolobii, apresentaram resistência ao $V$. dahliae. Os outros dois materiais classificados como resistentes a $M$. enterolobii, "CNPH 73" e "CNPH 79", estavam presentes no segundo experimento e foram classificados como suscetíveis, com ID maior que 50\%.

A classificação de todos os indivíduos como suscetíveis foi dada de acordo com a resistência vertical, que é monogênica ou oligogênica e raça específica, sendo "tudo ou nada". Porém, a resistência horizontal deve ser considerada neste caso, uma vez que esta é poligênica, controlada por vários genes que não são específicos para resistência a doenças, mas que regulam os processos naturais da planta e que combinados expressam a resistência (Van Der Plank, 1968). A resistência horizontal se expressa comparativamente a outros materiais em campo e é invariavelmente parcial e sujeita às variações de acordo com o meio ambiente e a agressividade do patógeno. Assim, a expressão de resistência dos genótipos tanto para Verticillium quanto para M. enterolobii, pode ser classificada como horizontal. O emprego da resistência horizontal em conjunto com outras práticas de controle, como manejo de água, pode ter efeitos aditivos ou mesmos sinérgicos para o manejo integrado da murcha de verticílio em berinjela e outras solanáceas.

No trabalho de Pinheiro et al. (2014a), os autores afirmam que as espécies classificadas como resistentes poderão ser utilizadas como porta-enxerto, mas para tanto são necessários detalhados estudos de compatibilidade com tomate, berinjela e jiló. 
Em conclusão, o presente estudo traz resultados até o momento inéditos para o conhecimento do potencial de S. scuticum como fonte de resistência para murcha de verticílio. Já confirmado como portador de resistência para M. enterolobii (Pinheiros et al., 2014a), acessos de S. scuticum, aparentemente, também podem ser portadores de resistência parcial para outra doença de solo, de etiologia fúngica, causada por $V$. dahliae, permitindo futura exploração como fonte de resistência ou porta-enxerto de Solanaceae cultivadas. Aparentemente, existem bons níveis de resistência a vários patógenos de solanáceas em $S$. scuticum, o que justifica a continuação de ensaios para ratificar esses indícios.

Experimentos com genótipos das espécies apresentadas no presente trabalho, que demonstraram alta resistência nos ensaios, devem ser repetidos e expandidos, com inclusão dos outros genótipos, incluindo aqueles classificados como resistentes ao nematoide das galhas. 


\section{REFERÊNCIAS}

AGRIOS, G. N. 2005. Plant Pathology. 5ed. Burlington - USA. Elsevier Academy Press.

BASAY, S.; SENIZ, V.; TEZCAN, H. 2011. Reactions of selected eggplant cultivars and lines to verticillium wilt caused by Verticillium dahliae Kleb. African Journal of Biotechnology 10(18): 3371-3373. (Short Communication).

BLETSOS, F. A.; Thanassoulopoulos, C. C.; Roupakias, D. G. 2003. Effect of grafting on growth, yield, and verticillium wilt of eggplant. Hortscience 36(2): 183-186.

BLETSOS, F. A.; Stavropouluos, N. I.; Papadopoulou, P. P.; Antonopoulou, P. D. 2004. Evaluation of eggplant (Solanum melongena L.) germplasm for resistance to Verticillium wilt. Advances in Hoticultural Science 18(1): 33-37.

COLLONNIER, C.; FOCK, I.; KASHYAP, V.; ROTINO, G. L.; DAUNAY, M. C.; LIAN, Y., MARISKA, I. K.; RAJAM, M. V.; SERVAES, A.; DUCREUX, G.; SIHACHAKR, D. 2001. Applications of biotechnology in eggplant. Plant Cell, Tissue and Organ Culture 65(2): 91-107.

COLLONNIER, C.; FOCK, I.; DAUNAY, M.C.; SERVARES, A., VEDEL, F., SILJAKYAKOVLEV, S.; SOUVANNAVONG, V.; SIHACHARK, D. 2003. Somatic hybrids between Solanum melongena an S. sisymbrifolium, as a useful source of resistance against bacterial and fungal wilts. Plant Science 164(5): 849-861.

DERIVI, S. C. N.; MENDEZ, M. H. M.; FRANCISCONI, A. D.; SILVA, C. S. DA; CASTRO, A. F. DE; LUZ, D. P. 2002. Efeito hipoglicêmico de rações à base de berinjela (Solanum melongena, L.) em ratos. Ciência e Tecnologia de Alimentos 22(2): 164-169.

EMATER-DF. Informativo da produção agrícola do Distrito Federal. Ano/Safra 2005/2006. Disponível em: www.emater.df.gov.br. Acesso em: 15 de jan. 2015.

FARIAS, E. A. DE P.; FERREIRA, R. L. F.; ARAUJO-NETO, S. E. DE; COSTA, F. C.; NASCIMENTO, D. S. 2013. Organic production of tomatoes in the amazon region by plants grafted on wild Solanum rootstocks. Ciência e Agrotecnologia 37(4): 323-329.

FERREIRA, D. F. 2003. Programa de análises estatísticas (statistical analysis sotware) e planejamento de experimentos - SISVAR 4.2 (Build 39). Lavras: DEX/UFLA.

FILGUEIRA, F. A. R. 2003. Cultura da berinjela. p. 312-320. IN: Filgueira, F. A. R. Solanáceas: agrotecnologia moderna na produção de tomate, batata, pimentão, pimenta, berinjela e jiló. 1ed. UFLA.

GONÇALVES, M. DA C. R.; DINIZ, M. DE F. F. M.; BORBA, J. D. C.; NUNES, X. P.; BARBOSA-FILHO, J. M. 2006. Berinjela (Solanum melongena L.) - mito ou realidade no combate as dislipidemias? Revista Brasileira de Farmacognosia 16(2): 252-257.

HAJJAR, R.; HODGKIN, T. 2007. The use of wild relatives in crop improvement: A survey of developments over the last 20 years. Euphytica 156(1-2): 1-13. 
INSTITUTO DE ECONOMIA AGRÍCOLA (IEA). Valor de produção dos principais produtos da agropecuária do estado de São Paulo, 2006. Disponível em: www.iea.sp.gov.br. Acesso em: 20 jan. 2015.

KANTHARAJAH, A. S. \& GOLEGAONKAR, P. G. 2004. Somatic embryogenesis in eggplant. Scientia Horticulrae 99(2): 107-117.

KUROZAWA, C.; PAVAN, M.A.; KRAUSE-SAKATE, R. 2005. Doenças das Solanáceas. p. 589-596 IN: Kimati, H.; Amorim, L.; Rezende, J.A.M.; Bergamini Filho, A.; Camargo, L.E.A. Manual de Fitopatologia - volume 2 - Doenças de Plantas Cultivadas. 4ed. Agronômica Ceres.

LAHKIM-TSOR, L.; HAZANOVSKY, M.; MORDECHI-LEBIUSH, S.; SIVAN, S. 2001. Aggressiveness of Verticillium dahliae isolates from different vegetative compatibility groups to potato and tomato. Plant Pathology 50(4): 477-482.

LIU, J.; ZHENG, Z.; ZHOU, X.; FENG, C.; ZHUANG, Y. 2015. Improving the resistance of eggplant (Solanum melongena) to verticillium wilt using wild species Solanum linnaeanum. Euphytica 201: 463-469.

MARTIELLO, R. R.; BARBIERI, R. L.; CARVALHO, F. I. F. 1997. Resistência de plantas a moléstias fúngicas. Ciência Rural 27(1): 161-168.

MCKINNEY, H. H. 1923. Influence of soil temperature and moisture on infection of wheat seedlings by Helminthosporium sativum. Journal of Agricultural Research 26(5): 195-217.

MICHEREFF, S. J.; ANDRADE, D. E. G. T.; PERUCH, L. A. M.; MENEZES, M. 2005. Importância dos patógenos e das doenças radiculares em solos tropicais. p. 1-18. IN: Michereff, S. J.; Andrade, D. E. G. T.; Menezes, M. Ecologia e Manejo de Patógenos Radiculares em Solos Tropicais. Recife: UFRPE, Imprensa Universitária.

MIRANDA, B. E. C DE; BOITEUX, L. S.; CRUZ, E. M.; REIS, A. 2010. Fontes de resistência em acessos de Solanum (secção Lycopersicon) a Verticillium dahliae raças 1 e 2. Horticultura Brasileira 28(4): 458-465.

NAIK, M. K.; RANI, G. S. D.; PRASADI, R. D.; PATIL, M. B.; SEN, B. 2008. An overview of soil borne plant pathogens. p. 1-33. IN: Advances In Soil Borne Plant Diseases. 1ed. New India Publishing Agency.

NASS, L. L. \& PATERNIANI, E. 2000. Pre-breeding: a link between genetic resources and maize breeding. Scientia Agricola 57(3): 581-587.

PARLEVLIET, J. E.; ZADOKS, J. C. 1977. The integrated concept of disease resistance: A new view including horizontal and vertical resistance in plants. Euphytica 26(1): 5-21.

PEREIRA, R. B.; MENDONÇA, J. L. DE M.; AGUIAR, F. M.; RIBEIRO, M. C. V.; PINHEIRO, J. B. 2014. Reação de acessos de jurubeba juna (Solanum stramonifolium) a Fusarium oxysporum f. sp. lycopersici raça 3. Brasília: Embrapa Hortaliças. 20p. (Boletim de Pesquisa e Desenvolvimento 113).

PINHEIRO, J. B.; MENDONÇA, J. L. DE M.; RODRIGUES, C. DA S.; PEREIRA, R. B.; SUINAGA, F. A. 2014a. Reação de Solanum scuticum a M. enterolobii. Brasília: Embrapa Hortaliças. 20p. (Boletim de Pesquisa e Desenvolvimento 106). 
PINHEIRO, J. B.; MENDONÇA, J. L. DE M.; RODRIGUES, C. DA S.; PEREIRA, R. B.; SUINAGA, F. A. 2014b. Avaliação de Solanum stramonifolium para reação a Meloidogyne enterolobii. Brasília: Embrapa Hortaliças. 20p. (Boletim de Pesquisa e Desenvolvimento 124).

REIS, A.; BOITEUX, L. S.; LOPES, C. A. 2011. Doenças da berinjela no Brasil. Brasília: Embrapa Hortaliças. 8p. (Circular Técnica).

SEKARA, A.; CEBULA, S.; KUNICK, E. 2007. Cultivated eggplants - origin, breeding objectives and genetic resources, a review. Folia Horticulturae 19: 97-114.

SIMÕES, A. C.; ALVES, G. E. B.; FERREIRA, R. L. F.; ARAUJO-NETO, S. E. DE. 2014. Compatibilidade de tomateiro sob diferentes portaenxertos e métodos de enxertia em sistema orgânico. Enciclopédia Biosfera 10(18): 961-972.

VALE, F. X. R. DO; PARLEVLIET, J. E.; ZAMBOLIM, L. 2001. Concepts in plant disease resistance. Fitopatologia Brasileira 26(3): 577-589.

VAN DER PLANK, J. E. 1968. Disease Resistance in Plants. Academic Press.

VIDA, J. B; ZAMBOLIM, L.; TESSMAN, D. J.; BRANDÃO FILHO, J. U. T.; VERZIGNASSI, J. R.; CAIXETA, M. P. 2004. Manejo de doenças de plantas em cultivo protegido. Fitopatologia Brasileira 29(4): 355-372. 
Tabela 1.1 - Isolados de Verticillium da coleção micológica do Laboratório de Fitopatologia do $\mathrm{CNPH}$.

\begin{tabular}{|c|c|c|c|}
\hline Isolado & $\begin{array}{c}\text { Hospedeira } \\
\text { original }\end{array}$ & $\begin{array}{l}\text { Origem } \\
\text { (estado) }\end{array}$ & Ano de coleta \\
\hline Vert. 02 & Tomate & São Paulo & 1992 \\
\hline Vert. 07 & Berinjela & Distrito Federal & 1995 \\
\hline Vert. 09 & Desconhecido & Inglaterra & 1997 \\
\hline Vert. 11 & Cacau & Bahia & 1997 \\
\hline Vert. 12 & Quiabo & Minas & 1997 \\
\hline Vert. 15 & Berinjela & São Paulo & 1997 \\
\hline Vert. 16 & Berinjela & São Paulo & 1997 \\
\hline Vert. 17 & Berinjela & São Paulo & 1997 \\
\hline Vert. 18 & Berinjela & São Paulo & 1997 \\
\hline Vert. 22 & Cacau & Bahia & 1997 \\
\hline Vert. 23 & Cacau & Inglaterra & 1997 \\
\hline Vert. 24 & Batata & Idaho (EUA) & 1997 \\
\hline Vert. 38 & Tomate & Santa Catarina & 2004 \\
\hline Vert. 52 & Tomate & São Paulo & 2005 \\
\hline Vert. 62 & Berinjela & São Paulo & 2005 \\
\hline Vert. 120 & Berinjela & Espírito Santo & 2010 \\
\hline Vert. 122 & Quiabo & Espírito Santo & 2010 \\
\hline Vert. 129 & Berinjela & Espírito Santo & 2010 \\
\hline Vert. 154 & Berinjela & Pernambuco & 2013 \\
\hline
\end{tabular}

Tabela 1.2 - Análise química do solo utilizado nos experimentos.

\begin{tabular}{|c|c|c|c|c|c|c|c|c|}
\hline \multirow{2}{*}{$\mathbf{p H}$} & $\mathbf{P}$ & $\mathbf{K}$ & $\mathbf{N a}$ & $\mathbf{C a}$ & $\mathbf{M g}$ & $\mathbf{A l}$ & $\mathbf{H}+\mathbf{A l}$ & $\begin{array}{c}\text { Matéria } \\
\text { Orgânica }\end{array}$ \\
\cline { 2 - 9 } & \multicolumn{3}{|c|}{$\mathbf{m g} / \mathbf{d m}^{\mathbf{3}}$} & \multicolumn{4}{c|}{$\mathbf{c m o l}_{\mathbf{c}} / \mathbf{d m}^{\mathbf{3}}$} & \\
\hline 5,90 & 16,0 & 103 & 5 & 5,8 & 2,6 & 0,00 & 1,8 & 33,7 \\
\hline
\end{tabular}


Tabela 1.3 - Genótipos de Solanum melongena submetidos à avaliação de resistência à Verticillium.

\begin{tabular}{|c|c|}
\hline Genótipo & Procedência \\
\hline BGH $312 *$ & Universidade Fedral de Viçosa - UFV \\
\hline BGH 509* & Universidade Fedral de Viçosa - UFV \\
\hline BGH 906* & Universidade Fedral de Viçosa - UFV \\
\hline BGH 907* & Universidade Fedral de Viçosa - UFV \\
\hline BGH 908* & Universidade Fedral de Viçosa - UFV \\
\hline BGH 909* & Universidade Fedral de Viçosa - UFV \\
\hline BGH 2404* & Universidade Fedral de Viçosa - UFV \\
\hline BGH $2447^{*}$ & Universidade Fedral de Viçosa - UFV \\
\hline BGH $2505^{*}$ & Universidade Fedral de Viçosa - UFV \\
\hline BGH 2541* & Universidade Fedral de Viçosa - UFV \\
\hline BGH 2579* & Universidade Fedral de Viçosa - UFV \\
\hline BGH $2605^{*}$ & Universidade Fedral de Viçosa - UFV \\
\hline BGH 2637* & Universidade Fedral de Viçosa - UFV \\
\hline BGH 2754* & Universidade Fedral de Viçosa - UFV \\
\hline BGH 2755* & Universidade Fedral de Viçosa - UFV \\
\hline BGH $2756^{*}$ & Universidade Fedral de Viçosa - UFV \\
\hline BGH 3350* & Universidade Fedral de Viçosa - UFV \\
\hline BGH 4982* & Universidade Fedral de Viçosa - UFV \\
\hline BGH 5991* & Universidade Fedral de Viçosa - UFV \\
\hline BGH 5992* & Universidade Fedral de Viçosa - UFV \\
\hline Flórida Market* & Feltrin $^{\circledR}$ \\
\hline Embu* & Isla Sementes \\
\hline Milan F1* & Top Seed $^{\circledR}$ \\
\hline Nápoli* & Sakata ${ }^{\circledR}$ \\
\hline Ciça* & $\mathrm{CNPH}$ \\
\hline Shoya Long* & Takii Seed \\
\hline CNPH 0704** & $\mathrm{CNPH}$ \\
\hline CNPH $0683 * *$ & $\mathrm{CNPH}$ \\
\hline CNPH 0690** & $\mathrm{CNPH}$ \\
\hline CNPH 0694** & $\mathrm{CNPH}$ \\
\hline CNPH 0721** & $\mathrm{CNPH}$ \\
\hline CIÇA** & $\mathrm{CNPH}$ \\
\hline CNPH $0705^{* *}$ & $\mathrm{CNPH}$ \\
\hline CNPH $0718 * *$ & CNPH \\
\hline
\end{tabular}

* Inoculação com suspensão mista de conídios, "Vert. 15" e "Vert. 120;

**Inoculação separada com suspensão de conídios de "Vert. 02", "Vert. 09", "Vert. 15" e "Vert. 120". 
Tabela 1.4 - Genótipos do gênero Solanum utilizados na avaliação de resistência em Janeiro e Julho de 2014.

\begin{tabular}{|c|c|}
\hline Espécie & Acesso CNPH \\
\hline S. stramonifolium & CNPH 19 \\
\hline S. stramonifolium & CNPH 20 \\
\hline S. stramonifolium & CNPH 21 \\
\hline S. stramonifolium & CNPH 22 \\
\hline S. stramonifolium & CNPH 23 \\
\hline S. stramonifolium & CNPH 24 \\
\hline S. stramonifolium & CNPH 25 \\
\hline S. stramonifolium & CNPH 107 \\
\hline S. stramonifolium & CNPH 108 \\
\hline S. stramonifolium & CNPH 109 \\
\hline S. stramonifolium & CNPH 110 \\
\hline S. stramonifolium & CNPH 111 \\
\hline S. stramonifolium & CNPH 112 \\
\hline S. stramonifolium & CNPH 113 \\
\hline S. stramonifolium & CNPH 114 \\
\hline S. stramonifolium & CNPH 115 \\
\hline S. stramonifolium & CNPH 116 \\
\hline S. stramonifolium & CNPH 117 \\
\hline S. stramonifolium & CNPH 118 \\
\hline S. stramonifolium & CNPH 119 \\
\hline S. stramonifolium & CNPH 120 \\
\hline S. stramonifolium & CNPH 121 \\
\hline S. stramonifolium & CNPH 122 \\
\hline S. stramonifolium & CNPH 124 \\
\hline S. stramonifolium & CNPH 336 \\
\hline S. stramonifolium & CNPH 349 \\
\hline S. melongena * & Berinjela cv. Ciça \\
\hline S. melongena * & Berinjela 171 \\
\hline S. melongena* & Berinjela 778 \\
\hline S. lycopersicum* & Tomate L-18-9 \\
\hline S. lycopersicum* & Tomate S-43-5 \\
\hline Híbrido S. stramonifolium / S. melongena* & Jurubeba Vermelha/ Berinjela 218 \\
\hline Híbrido S. stramonifolium / S. gilo* & Jurubeba Vermelha/ Jiló 218 \\
\hline
\end{tabular}

\footnotetext{
* Espécies utilizadas apenas no experimento de Janeiro de 2014.
} 
Tabela 1.5 - Genótipos de Solanum scuticum e testemunha utilizados na avaliação de resistência.

\begin{tabular}{|c|c|}
\hline $\begin{array}{l}\text { Acessos Solanum scuticum avaliados em } \\
\text { maio/2014 }\end{array}$ & $\begin{array}{c}\text { Acessos Solanum scuticum avaliados em } \\
\text { setembro/2014 }\end{array}$ \\
\hline CNPH 01 & CNPH 345 \\
\hline CNPH 04 & CNPH 348 \\
\hline CNPH 02 & CNPH 353 \\
\hline CNPH 07 & CNPH 350 \\
\hline CNPH 08 & CNPH 103 \\
\hline CNPH 11 & CNPH 102 \\
\hline CNPH 12 & CNPH 217 \\
\hline CNPH 13 & CNPH 230 \\
\hline CNPH 14 & CNPH 94 \\
\hline CNPH 15 & CNPH 225 \\
\hline CNPH 18 & CNPH 239 \\
\hline CNPH 17 & CNPH 95 \\
\hline CNPH 57 & CNPH 96 \\
\hline CNPH 40 & CNPH 97 \\
\hline CNPH 39 & CNPH 101 \\
\hline CNPH 68 & CNPH 99 \\
\hline CNPH 64 & CNPH 87 \\
\hline CNPH 58 & CNPH 82 \\
\hline CNPH 51 & CNPH 83 \\
\hline CNPH 49 & CNPH 92 \\
\hline CNPH 48 & CNPH 93 \\
\hline CNPH 57 & CNPH 79 \\
\hline CNPH 53 & CNPH 75 \\
\hline CNPH 52 & CNPH 76 \\
\hline CNPH 63 & CNPH 73 \\
\hline Berinjela cv. Ciça & Berinjela cv. Ciça \\
\hline
\end{tabular}


Tabela 1.6 - Reação de genótipos de Solanum melongena à mistura de "Vert. 15" e "Vert. $120 "$.

\begin{tabular}{|c|c|c|c|}
\hline Genótipos & Procedência & ID & Reação \\
\hline BGH 509 & Universidade Fedral de Viçosa - UFV & 0,0 a & AR \\
\hline BGH 2637 & Universidade Fedral de Viçosa - UFV & 0,0 a & AR \\
\hline BGH 907 & Universidade Fedral de Viçosa - UFV & 0,0 a & AR \\
\hline BGH 5991 & Universidade Fedral de Viçosa - UFV & 0,0 a & AR \\
\hline BGH 312 & Universidade Fedral de Viçosa - UFV & 5,5 a & $\mathrm{R}$ \\
\hline BGH 2605 & Universidade Fedral de Viçosa - UFV & 5,5 a & $\mathrm{R}$ \\
\hline BGH 4982 & Universidade Fedral de Viçosa - UFV & 8,3 a & $\mathrm{R}$ \\
\hline BGH 2754 & Universidade Fedral de Viçosa - UFV & $11,1 \mathrm{a}$ & $\mathrm{R}$ \\
\hline BGH 2404 & Universidade Fedral de Viçosa - UFV & $11,1 \mathrm{a}$ & $\mathrm{R}$ \\
\hline BGH 5992 & Universidade Fedral de Viçosa - UFV & 25,0 b & $\mathrm{S}$ \\
\hline BGH 909 & Universidade Fedral de Viçosa - UFV & 27,7 b & $S$ \\
\hline BGH 906 & Universidade Fedral de Viçosa - UFV & 30,5 b & S \\
\hline BGH 2505 & Universidade Fedral de Viçosa - UFV & 30,5 b & $S$ \\
\hline Shoya Long & Takii Seed & 33,3 b & $S$ \\
\hline BGH 908 & Universidade Fedral de Viçosa - UFV & $36,1 \mathrm{c}$ & S \\
\hline Napoli & Sakata ${ }^{\circledR}$ & $38,8 \mathrm{c}$ & $S$ \\
\hline Embu & Isla Sementes & $41,6 \mathrm{c}$ & $S$ \\
\hline BGH 2755 & Universidade Fedral de Viçosa - UFV & 47,2 c & $S$ \\
\hline $\mathrm{ClÇA}$ & $\mathrm{CNPH}$ & $50,0 \mathrm{c}$ & $S$ \\
\hline BGH 2447 & Universidade Fedral de Viçosa - UFV & $52,7 \mathrm{c}$ & $S$ \\
\hline Florida Market & Feltrin ${ }^{\circledR}$ & $61,1 \mathrm{~d}$ & $S$ \\
\hline BGH 2756 & Universidade Fedral de Viçosa - UFV & $69,4 d$ & $S$ \\
\hline BGH 2541 & Universidade Fedral de Viçosa - UFV & $69,4 d$ & $S$ \\
\hline Milan & Top Seed $®$ & $69,4 d$ & $\mathrm{~S}$ \\
\hline BGH 2579 & Universidade Fedral de Viçosa - UFV & $72,2 \mathrm{~d}$ & $\mathrm{~S}$ \\
\hline BGH 3350 & Universidade Fedral de Viçosa - UFV & $75,0 \mathrm{~d}$ & $S$ \\
\hline
\end{tabular}

CV (\%) $\quad 38,7$

- Letras iguais não diferem entre si na coluna de acordo com o teste Scott-Knott 5\%.

AR=Altamente Resistente; $R=$ Resistente; $S$ = Suscetível. 
Tabela 1.7 - Índice de doença (\%) de genótipos de Solanum melongena aos isolados "Vert. 09"; "Vert. 15"; "Vert. 120" e "Vert. 02".

\begin{tabular}{|c|c|c|c|c|c|}
\hline Genótipo & $\begin{array}{l}\text { Média ID } \\
\text { (Genótipos) }\end{array}$ & Vert. 02 & Vert. 15 & Vert. 120 & Vert. 09 \\
\hline CNPH 721 & 59,3 a & 68,7 a & 54,1 a & 62,5 a & $52,0 \quad$ b \\
\hline CNPH 718 & 61,9 a & 75,0 a & 56,2 a & 64,5 a & $52,0 \quad$ b \\
\hline CNPH 704 & 64,5 a & 70,8 a & 64,5 b & $83,3 \quad$ c & 39,5 a \\
\hline CNPH 705 & $70,8 \quad$ b & $100,0 \mathrm{c}$ & 79,1 c & 72,9 b & 31,2 a \\
\hline CNPH 690 & 73,9 c & $79,1 \quad b$ & $77,0 \quad$ c & $77,0 \quad$ c & $62,5 \mathrm{c}$ \\
\hline CIÇA & $75,0 \quad$ c & 81,2 b & 79,1 c & $83,3 \quad$ c & 56,2 b \\
\hline CNPH 694 & $82,8 d$ & $100,0 \mathrm{c}$ & 85,4 c & 72,9 b & $72,9 \quad \mathrm{~d}$ \\
\hline CNPH 683 & 86,4 d & 97,9 c & $83,3 \mathrm{c}$ & $85,4 \quad c$ & 79,1 d \\
\hline Média (Isolados) & & $84,1 \mathrm{C}$ & 72,3 B & 75,2 B & $55,7 \mathrm{~A}$ \\
\hline
\end{tabular}

- Letras minúsculas iguais não diferem entre si na coluna e maiúsculas na linha de acordo com o teste Scott-Knott $5 \%$.

Tabela 1.8 - Efeito de diferentes isolados de Verticillium dahliae na altura de genótipos de Solanum melongena.

\begin{tabular}{|c|c|c|}
\hline \multirow{2}{*}{ Isolado } & \multicolumn{2}{|c|}{$\begin{array}{c}\text { Média Geral } \\
\text { (Isolado x Genótipos) }\end{array}$} \\
\hline & $\begin{array}{c}\text { Altura } \\
(\mathrm{cm})\end{array}$ & $\begin{array}{c}\text { Crescimento } \\
\text { (\%) }\end{array}$ \\
\hline Vert. 02 & $9,7 \mathbf{a}$ & $49,6 \mathbf{a}$ \\
\hline Vert. 120 & $12,3 \mathbf{b}$ & $62,6 \mathrm{~b}$ \\
\hline Vert. 15 & $13,3 \mathrm{c}$ & $67,7 \mathrm{c}$ \\
\hline Vert. 09 & $14,0 \mathrm{c}$ & $71,4 \mathrm{~d}$ \\
\hline Testemunha & 20,2 d & 100,0 e \\
\hline (não inoculada) & & \\
\hline CV (\%) & 13,3 & 9,02 \\
\hline
\end{tabular}

Letras iguais não diferem entre si na coluna de acordo com o teste Scott-Knott 5\%. 
Tabela 1.9 - Efeito de diferentes isolados de Verticillium dahliae na altura de genótipos de Solanum melongena

\begin{tabular}{|c|c|c|c|c|c|c|}
\hline \multirow[b]{2}{*}{$\begin{array}{c}\text { Genótipos } \\
\text { (CNPH) }\end{array}$} & \multirow[b]{2}{*}{$\begin{array}{c}\text { Média de } \\
\text { Crescimento(\%) }\end{array}$} & \multicolumn{5}{|c|}{ Isolados } \\
\hline & & Vert. 02 & Vert. 120 & Vert. 15 & Vert. 09 & $\begin{array}{l}\text { Testemunha } \\
\text { (não inoculada) }\end{array}$ \\
\hline 683 & $61,0 \mathbf{a}$ & $45,2 \mathrm{aA}$ & $57,1 \mathrm{aB}$ & $58,4 \mathrm{aB}$ & 44,5 aA & $100 \mathrm{aC}$ \\
\hline 705 & 62,6 a & 41,9 aA & $56,5 \mathrm{aB}$ & $56,5 \mathrm{aB}$ & 58,1 bB & $100 \mathrm{aC}$ \\
\hline 718 & 67,1 b & $45,1 \mathrm{aA}$ & 65,4 bB & 53,5 aA & 71,6 cB & $100 \mathrm{aC}$ \\
\hline 721 & 67,3 b & 44,9 aA & $58,9 a B$ & 63,7 aB & 69,0 cB & $100 \mathrm{aB}$ \\
\hline $\mathrm{CIÇA}$ & $73,7 \mathrm{c}$ & 51,1 bA & $65,0 \mathrm{bB}$ & 77,2 bc & 75,2 cC & 100 aD \\
\hline 694 & $74,0 \mathrm{c}$ & 52,6 bA & $58,2 \mathrm{aA}$ & $82,7 \mathrm{bB}$ & 76,4 cB & $100 \mathrm{aC}$ \\
\hline 690 & $78,2 \mathrm{~d}$ & 54,7 bA & $73,0 \mathrm{bB}$ & 76,5 bB & $86,6 \mathrm{dC}$ & 100 aD \\
\hline 704 & $78,2 \mathrm{~d}$ & 61,2 bA & 66,7 bA & 73,2 bA & $90,0 \mathrm{~dB}$ & $100 \mathrm{aB}$ \\
\hline CV (\%) & 9,02 & & & & & \\
\hline
\end{tabular}

- Letras minúsculas iguais não diferem entre si na coluna e maiúsculas na linha de acordo com o teste Scott-Knott 5\%. 
Tabela 1.10 - Dados conjuntos da reação de Solanum stramonifolium à mistura de isolados "Vert. 15" e "Vert. 120".

\begin{tabular}{|c|c|c|c|c|}
\hline \multirow{3}{*}{ Genótipo } & \multicolumn{4}{|c|}{ ID } \\
\hline & \multirow[b]{2}{*}{ Janeiro } & \multicolumn{3}{|c|}{ Janeiro + Julho } \\
\hline & & Julho & & Reação \\
\hline CNPH 20 & $13,8 \mathrm{a}$ & $22,2 \mathrm{a}$ & $18,0 \mathrm{a}$ & $\mathrm{R}$ \\
\hline CNPH 120 & 13,8 a & $25,0 \mathrm{a}$ & 19,4 a & $\mathrm{R}$ \\
\hline CNPH 336 & $16,6 \mathrm{a}$ & $27,7 \mathrm{a}$ & 22,2 b & $\mathrm{R}$ \\
\hline CNPH 22 & $25,0 \mathrm{a}$ & $22,2 \mathrm{a}$ & $23,6 \mathbf{b}$ & $\mathrm{R}$ \\
\hline CNPH 21 & 13,8 a & 38,8 a & $26,6 \mathrm{c}$ & S \\
\hline CNPH 24 & 30,5 a & $27,7 \mathrm{a}$ & $29,1 \mathrm{~d}$ & $S$ \\
\hline CNPH 122 & $25,0 \mathrm{a}$ & $36,1 \mathrm{a}$ & $30,5 \mathrm{~d}$ & $S$ \\
\hline CNPH 112 & 27,7 a & $36,1 \mathbf{a}$ & $31,9 \mathbf{d}$ & $S$ \\
\hline CNPH 23 & $38,8 \mathrm{a}$ & 30,5 a & 34,7 e & $S$ \\
\hline CNPH 117 & 24,9 a & 47,2 b & 36,1 e & S \\
\hline CNPH 25 & $44,4 a$ & $27,7 \mathrm{a}$ & 36,1 e & $S$ \\
\hline CNPH 349 & $50,0 \mathrm{a}$ & $27,7 \mathrm{a}$ & 38,8 e & $S$ \\
\hline CNPH 111 & $25,0 \mathrm{a}$ & $55,5 \mathbf{b}$ & 40,2 f & $S$ \\
\hline CNPH 118 & $22,2 \mathrm{a}$ & $61,1 \mathbf{b}$ & $41,6 \mathbf{f}$ & $S$ \\
\hline CNPH 107 & $36,1 \mathrm{a}$ & 47,2 b & $41,6 \mathbf{f}$ & $S$ \\
\hline CNPH 119 & $38,8 \mathrm{a}$ & 44,4 a & $41,6 \mathrm{f}$ & $S$ \\
\hline CNPH 116 & $41,6 \mathrm{a}$ & $41,6 \mathrm{a}$ & $41,6 \mathrm{f}$ & $S$ \\
\hline CNPH 114 & $50,0 \mathrm{a}$ & 33,3 a & $41,6 \mathrm{f}$ & $S$ \\
\hline CNPH 110 & 49,9 a & $36,1 \mathrm{a}$ & $43,0 f$ & $S$ \\
\hline CNPH 19 & $41,6 \mathrm{a}$ & 47,2 b & $44,4 \mathbf{f}$ & $S$ \\
\hline CNPH 124 & $58,3 \mathbf{b}$ & 49,9 b & $54,1 \mathbf{g}$ & $S$ \\
\hline CNPH 121 & $47,2 \mathrm{a}$ & $63,8 \mathbf{b}$ & $55,5 \mathbf{g}$ & $S$ \\
\hline CNPH 109 & 69,4 b & $41,6 \mathrm{a}$ & $55,5 \mathbf{g}$ & $S$ \\
\hline CNPH 108 & 69,4 b & $52,7 \mathbf{b}$ & $61,1 \mathrm{~h}$ & $S$ \\
\hline CNPH 115 & $73,6 \mathbf{b}$ & $55,5 \mathbf{b}$ & $64,5 \mathbf{i}$ & $S$ \\
\hline CNPH 113 & $61,1 \mathbf{b}$ & 69,4 b & $65,2 \mathbf{i}$ & $\mathrm{S}$ \\
\hline Berinjela cv. Ciça & $75,0 \mathrm{~b}$ & 88,8 b & $81,9 \mathbf{j}$ & $S$ \\
\hline Jurubeba Vermelha/ Jiló 218 & $62,5 \mathrm{~b}$ & $*$ & $*$ & $S$ \\
\hline Berinjela 171 & 72,2 b & $*$ & $*$ & $S$ \\
\hline Tomate S-43-5 & 74,9 b & $*$ & $*$ & $S$ \\
\hline Berinjela 778 & 80,5 b & $*$ & $*$ & $S$ \\
\hline Jurubeba Verm./ Berinjela 218 & 86,1 b & * & $*$ & S \\
\hline Tomate L-18-9 & 94,4 b & $*$ & $*$ & S \\
\hline Média & $40,1 \mathrm{~A}$ & 42,9 B & & \\
\hline CV (\%) & 55,73 & 39,94 & 7,34 & \\
\hline
\end{tabular}

\footnotetext{
* Genótipos não utilizados no experimento.
} 
Tabela 1.11 - Reação de genótipos de Solanum scuticum à mistura do isolado "Vert. 120" e "Vert. 15".

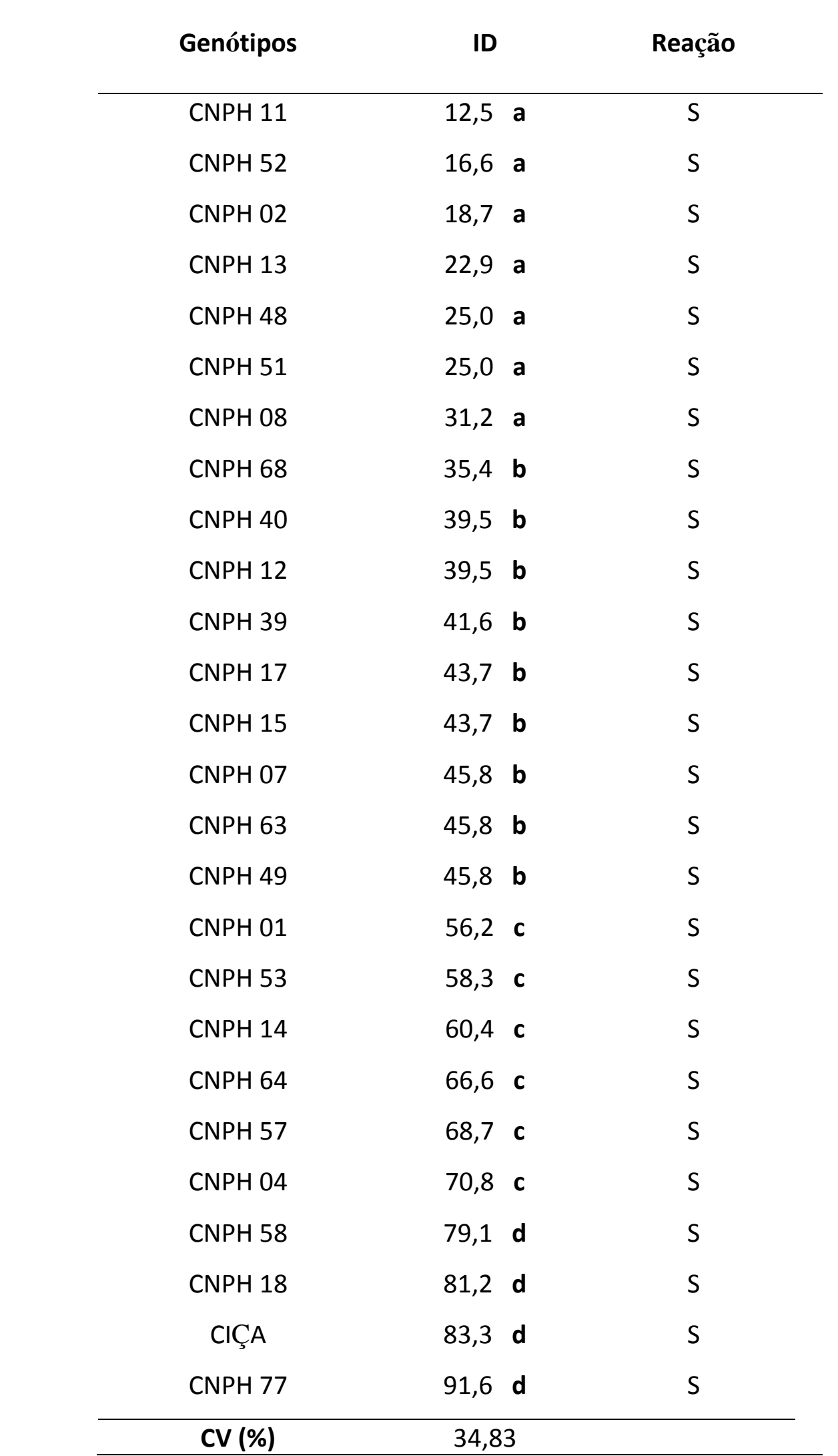

- Letras iguais não diferem entre si na linha de acordo com o teste Scott-Knott 5\%. $\mathrm{S}=$ Suscetível 
Tabela 1.12 - Reação de genótipos de Solanum scuticum à mistura dos isolados “Vert. 120" e "Vert. 15".

\begin{tabular}{|c|c|c|}
\hline Genótipos & ID & Reação \\
\hline CNPH 88 & 36,1 a & $S$ \\
\hline CNPH 99 & 38,8 a & $S$ \\
\hline CNPH 345 & 47,2 a & $S$ \\
\hline CNPH 73 & 50,0 a & $S$ \\
\hline CNPH 83 & 50,0 a & $S$ \\
\hline CNPH 225 & 52,7 a & $S$ \\
\hline CNPH 350 & 52,7 a & S \\
\hline CNPH 75 & 52,7 a & $S$ \\
\hline CNPH 79 & 55,5 a & $S$ \\
\hline CNPH 102 & 55,5 a & $S$ \\
\hline CNPH 96 & 58,3 a & $S$ \\
\hline CNPH 76 & 58,3 a & S \\
\hline CNPH 97 & 61,1 b & S \\
\hline CNPH 82 & 61,1 b & $S$ \\
\hline CNPH 95 & 61,1 b & S \\
\hline CNPH 92 & 63,8 b & $S$ \\
\hline CNPH 230 & 63,8 b & S \\
\hline CNPH 353 & 66,6 b & S \\
\hline CNPH 348 & 66,6 b & $\mathrm{S}$ \\
\hline CNPH 217 & 66,6 b & S \\
\hline CNPH 101 & 69,4 b & $S$ \\
\hline CNPH 93 & 69,4 b & $S$ \\
\hline CNPH 103 & 75,0 b & $S$ \\
\hline CNPH 239 & 75,0 b & $S$ \\
\hline CNPH 94 & 77,7 b & S \\
\hline CIÇA & 88,8 b & $S$ \\
\hline CV (\%) & 21,31 & \\
\hline
\end{tabular}


Figura 1.1 - Agressividade dos isolados de Verticillium a genótipos de Solanum melongena.

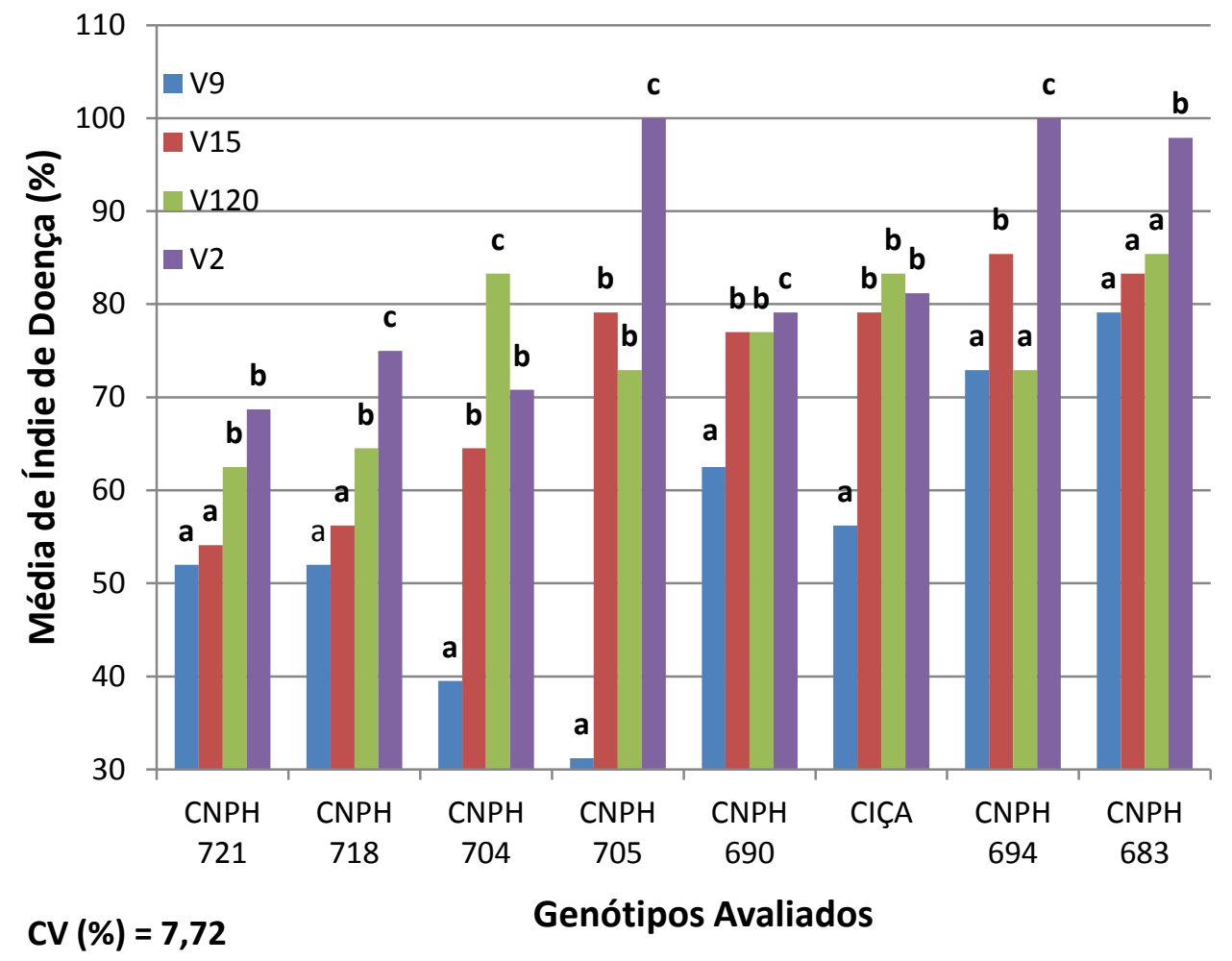




\section{CAPÍTULO 2}

Manejo da irrigação para controle da murcha de verticílio em berinjela 


\section{RESUMO}

Patógenos vasculares, causadores de murchas, têm grande importância na produção de berinjela (Solanum melongena L.). A murcha de verticílio (Verticillium dahliae Kleb.) é uma das principais doenças vasculares da cultura. Como não existem cultivares comerciais com resistência genética à doença, o manejo preventivo é de suma importância na produção de berinjela, uma vez que o controle curativo é não é possível. Dentre as práticas de manejo da cultura, a irrigação pode interferir de forma significativa no ciclo de vida do patógeno e, consequentemente, no desenvolvimento de epidemias de murcha. Alguns estudos relatam que a doença é favorecida pela maior umidade do solo, enquanto outros pelo déficit hídrico. $\mathrm{O}$ objetivo do presente trabalho foi avaliar a relação entre a disponibilidade de água no solo e a ocorrência de murcha da murcha de verticílio na cultura da berinjela, de forma a identificar estratégias de manejo da água de irrigação capazes de desfavorecer o patógeno e retardar o progresso da doença. O experimento foi conduzido na Estação Experimental de Biologia da Universidade de Brasília, Distrito Federal. Foram transplantadas mudas de berinjela cv. Ciça em tanques de concreto de $0,64 \mathrm{~m}^{2}$ e 1,0 $\mathrm{m}$ de profundidade. Os tratamentos, aplicados em solo inoculado com $V$. dahliae e em solo indene (controle), corresponderam em irrigar as plantas quando a água disponível no solo fosse reduzida para $90 \%\left(\mathrm{AD}_{90 \%}\right), 55 \%\left(\mathrm{AD}_{55 \%}\right)$ e $20 \%\left(\mathrm{AD}_{20 \%}\right)$, durante todo o ciclo de cultivo, e quando atingisse $20 \%$ no estádio vegetativo e $90 \%$ no estádio de produção $\left(\mathrm{AD}_{20-90 \%}\right)$. O delineamento experimental foi blocos ao acaso, com três repetições e oito tratamentos, dispostos em esquema fatorial (4 x 2). O tratamento $\mathrm{AD}_{20-90 \%}$ acarretou redução de $42 \%$ na severidade da doença, relativo à média dos demais tratamentos, e menor altura de lesão no xilema provocada pelo, a qual não diferiu significativamente dos tratamentos $\mathrm{AD}_{55 \%}$ e $\mathrm{AD}_{20 \%}$. A produção de massa seca da parte aérea (exceto fruto) no tratamento $\mathrm{AD}_{20-90 \%}$ não diferiu dos demais, sendo que a produção no tratamento $\mathrm{AD}_{90 \%}$ foi significativamente maior que nos $\mathrm{AD}_{55 \%}$ e $\mathrm{AD}_{20 \%}$, tanto em solo 
inoculado quanto indene. A incidência de doenças, inexistente em solo indene, não foi afetada pelos tratamentos de irrigação em solo inoculado (média de 72\%). Não houve efeito significativo dos fatores avaliados sobre a altura de plantas. A estratégia de manejo que se mostrou mais viável para reduzir a murcha de verticílio, sem prejudicar a produção de massa seca, foi irrigar com déficit hídrico $\left(\mathrm{AD}_{20 \%}\right)$ durante o estádio vegetativo e de forma plena $\left(\mathrm{AD}_{90 \%}\right)$ durante o estádio de produção.

Palavras-chave: Solanum melongena, Verticillium dahliae, eggplant, manejo de irrigação 


\section{ABSTRACT}

Vascular pathogens, that cause plant wilt, have great importance in eggplant (Solanum melongena L.) cultivation. Verticillium wilt (Verticillium dahliae Kleb.) is one of the mayor disease of the crop. Since there is no commercial cultivars with genetic resistance to this disease, preventive management is very important for eggplant production, since curative control is not possible. Among of the crop management practices, the irrigation can interfere significantly in the pathogen life cycle and consequently in the development of the disease. Some studies reported that the disease is favored by higher soil moisture, while others by drought conditions. The aim of this study was to evaluate the relationship between water availability in the soil and occurrence of Verticillium wilt in eggplant, in order to identify irrigation strategies that do not favor the pathogen and slow the progress of the disease. The experiment was carried out at the Experimental Station of Biology of University of Brasília, Federal District, Brazil. Eggplant seedlings, cultivar "Ciça", were transplanted into concrete tanks $-0.64 \mathrm{~m}^{2}$ and $1.0 \mathrm{~m}$ deep. The treatments, applied in soil artificially inoculated with $V$. dahliae and non inoculated soil (control), consisted in irrigated the plants when the amount of available water in soil were reduced to $90 \%\left(\mathrm{AD}_{90 \%}\right) ; 55 \%\left(\mathrm{AD}_{55 \%}\right)$ and $20 \%\left(\mathrm{AD}_{20 \%}\right)$, throughout the crop cycle, and when the soil reached $20 \%$ during the vegetative stage and $90 \%$ during the production phase $\left(\mathrm{AD}_{20-90 \%}\right)$. The experimental design was randomized block with three replications and eight treatments, arranged in a factorial $(4 \times 2)$. The treatment $\mathrm{AD}_{20-}$ $90 \%$ reduces in $42 \%$ the severity of the disease, compared with the average of the others treatments, and shorter length of xylem injury caused by the pathogen, which was not significantly distinct of $\mathrm{AD}_{55 \%}$ and $\mathrm{AD}_{20 \%}$. The dry matter production of shoot (except fruitage) in treatment $\mathrm{AD}_{20 \%}$ did not differ from the others, but the production in treatment $\mathrm{AD}_{90 \%}$ was significantly higher than $\mathrm{AD}_{55 \%}$ and $\mathrm{AD}_{20 \%}$, in soil with and without inoculation. The incidence of the disease, absent in non-inoculated soil treatments, was not affected by 
irrigation treatments in inoculated soil (average of $72 \%$ ). There was no significant effect of the evaluated factor on plant height. The most effective management strategy to reduce Verticillium wilt, without decrease dry matter production, was to irrigate with water deficit $\left(\mathrm{AD}_{20 \%}\right)$ during the vegetative stage and plenary $\left(\mathrm{AD}_{90 \%}\right)$ during the production phase.

Key words: Solanum melongena, Verticillium dahliae, eggplant, irrigation management 


\section{INTRODUÇÃO}

A berinjela (Solanum melongena L.), originária da Ásia, foi inicialmente cultivada como planta ornamental a alguns milhares de anos. Foi introduzida na Europa pelos árabes, através da Península Ibérica, durante a Idade Média e no Brasil por colonizadores portugueses no século VXI (Filgueira, 2003; Madeira et al., 2008). Segundo Marouelli et al. (2014a), em torno de $78 \%$ da produção nacional, estimada em 90 mil toneladas, concentra-se na região Sudeste. São Paulo é o principal estado produtor, sendo responsável por aproximadamente $43 \%$ da produção brasileira, seguido de Minas Gerais (20\%) e Rio de Janeiro (15\%).

As plantas têm porte arbustivo, com caule semi-lenhoso e ereto e atingem altura entre $1,0 \mathrm{~m}$ e $1,8 \mathrm{~m}$. O sistema radicular é bem desenvolvido, podendo alcançar profundidades acima de 1,0 m. Embora apresente tolerância moderada à seca, a irrigação pode propiciar incrementos de produtividade mesmo em regiões com períodos de estiagem relativamente curtos. Por outro lado, as plantas de berinjela desenvolvem-se melhor em solos bem drenados e profundos, não sujeitos ao encharcamento. Assim, é necessário que as regas sejam feitas de forma correta, evitando-se falta ou excesso, para um bom rendimento da cultura (Marouelli et al., 2014a).

A produção de berinjela é afetada por alguns patógenos comuns às solanáceas. Por ser uma das culturas mais rústicas da família, os problemas de doenças na cultura ocorrem com menos frequência que no tomateiro e na batateira, por exemplo, mas podem causar sérios danos, sobretudo em condições de irrigações excessivas, excesso de chuva e/ou solos compactados (Reis et al., 2011; Marouelli et al., 2014a).

Dos problemas fitossanitários da berinjela, os patógenos de solo causadores de murcha são os que mais preocupam os produtores, pois além de causar perdas na produção, 
comprometem o terreno para cultivos futuros de berinjela e de outras solanáceas. Dentre as doenças causadas por esses fitopatógenos de solo, Ribeiro (1998) destacam a murcha bacteriana (Ralstonia solanacearum), a murcha de fitófitora (Phytophthora capsici), a podridão de esclerotínia (Sclerotinia sclerotiorum) e a murcha de verticílio (Verticillium dahliae). Segundo Naik et al. (2008), a murcha de verticílio é uma das principais doenças da berinjela, causando grandes perdas econômicas em todo o mundo.

O fungo $V$. dahliae Kleb. tem capacidade de sobreviver no solo através de microescleródios formados em hifas maduras. Em meio de cultura produz conidióforos verticilados, eretos e septados que produzem, nas extremidades, conídios unicelulares e hialinos. Na presença do hospedeiro suscetível, o fungo penetra na raiz da planta e coloniza o seu xilema, causando murcha e amarelecimento das folhas, a partir do bordo em forma de "V", com vértice voltado para a nervura principal, e posterior necrose do tecido foliar (Kurozawa et al., 2005). Plantas de berinjela infectadas $V$. dahliae podem apresentar tamanho reduzido em relação a plantas sadias, podendo chegar ao colapso (Reis et al., 2011). A disseminação do fundo ocorre por sementes e mudas contaminadas, equipamento e máquinas contaminados e água da irrigação ou de chuva. Como o patógeno tem uma ampla gama de hospedeiras, tanto cultivadas como silvestres, plantas e restos culturais contaminados são fontes de inóculo para o solo (Agrios, 2005).

Ao ser infectada, não há controle químico para reestabelecer a sanidade da planta. Desta forma, o manejo preventivo da doença é a forma mais eficiente de lidar com o patógeno, pois não são conhecidos cultivares comerciais com resistência genética. Neste contexto destaca-se o manejo cultural integrado em áreas em que o patógeno está estabelecido, que inclui a adoção de práticas como solarização e rotação de cultura com famílias botânicas de plantas não hospedeiras, tal como a Brassicaceae, na tentativa de reduzir a quantidade inicial de inóculo no ambiente. Estas práticas de manejo podem, no entanto, não serem suficientemente 
eficientes para reduzir a doença a níveis satisfatórios (Tamietti \& Valentino, 2001; Yildz \& Benlioglu, 2010; Larkim et al., 2011).

Adicionalmente, sabe-se que a água e, consequentemente, a irrigação interferem de forma significativa no ciclo de vida do patógeno. Segundo Lopes et al. (2006), a frequência de irrigação, a quantidade de água aplicada e a forma com que a água é aplicada às plantas podem afetar o processo de estabelecimento do patógeno, assim como da incidência e severidade da doença. No caso do Verticillium, a interação da doença com a água é complexa, havendo divergência na literatura. Há relatos relacionando o aumento da incidência da doença tanto à solos mais úmidos (Xiao \& Subbarao, 2000; Jefferson \& Gossen, 2002) quanto à redução da lâmina de água aplicada (Arbogast et al., 1999.)

O objetivo deste trabalho foi investigar a relação entre a disponibilidade de água no solo e a severidade da murcha de verticílio na cultura de berinjela, assim como propor uma estratégia de manejo da água capaz de desfavorecer o patógeno e retardar o progresso da doença. 


\section{MATERIAIS E MÉTODOS}

O experimento foi conduzido na Estação Experimental de Biologia da Universidade de Brasília - UnB (EEB - UnB) -, Brasília, Distrito Federal, latitude 15²4’S, longitude $47^{\circ} 53^{\prime} \mathrm{W}$ e altitude de $1.110 \mathrm{~m}$, no período entre junho de 2014 a janeiro de 2015 . Segundo classificação de Köppen-Geiger, o clima da região é tipo Cwa (tropical de altitude).

\section{Tratamentos e delineamento experimental}

Foram avaliadas quatro estratégias de manejo da água de irrigação na cultura da berinjela cultivada em solo inoculado com isolados de $V$. dahliae e em solo sem inoculação (controle). Os tratamentos de irrigação corresponderam em regar as plantas de berinjela sempre que água disponível no solo fosse reduzida para $90 \%\left(\mathrm{AD}_{90 \%}\right), 55 \%\left(\mathrm{AD}_{55 \%}\right)$ e $20 \%$ $\left(\mathrm{AD}_{20 \%}\right)$ durante todo o ciclo de desenvolvimento das plantas. No quarto tratamento de irrigação, as plantas eram regadas quando a água disponível no solo atingia $20 \%$ durante o estádio vegetativo e $90 \%$ durante o estádio de produção $\left(\mathrm{AD}_{20-90 \%}\right)$. Assim, os níveis $\mathrm{AD}_{90 \%}$, $\mathrm{AD}_{55 \%}$ e $\mathrm{AD}_{20 \%}$ expressavam condições de solo com umidade alta, moderada e baixa, respectivamente.

O delineamento experimental adotado foi o de blocos ao acaso, com três repetições e oito tratamentos dispostos em esquema fatorial ( 4 x 2), sendo o primeiro fator representado pela água disponível no solo $\left(\mathrm{AD}_{90 \%}, \mathrm{AD}_{55 \%}, \mathrm{AD}_{20 \%}\right.$ e $\left.\mathrm{AD}_{20-90 \%}\right)$ e o segundo pela inoculação do solo (com e sem a presença de inóculo de $V$. dahliae).

\section{Unidade experimental}

$\mathrm{O}$ experimento foi conduzido em tanques de concreto com área de $0,64 \mathrm{~m}^{2}(0,80 \mathrm{~m} \mathrm{x}$ 0,80 m) e que se elevavam a 1,00 m acima da superfície do terreno. As paredes laterais e o 
fundo dos tanques, com espessura de $0,15 \mathrm{~m}$, eram impermeáveis e não permitiam passagem de umidade entre tanques. Na parede lateral de cada tanque existia, ao nível da superfície do terreno, uma abertura de $20 \mathrm{~mm}$ de diâmetro para drenagem de excesso de água.

Os tanques eram posicionados ao longo de uma mesma fileira contínua, sendo protegidos por cobertura fixa semitransparente, com pé direito de 2,50 m e largura de 3,20 m, para evitar molhamento pela chuva. Toda a estrutura, incluindo tanques e cobertura, eram fixas. Adicionalmente às vinte e quatro parcelas experimentais, foram cultivados dois tanques, a título de bordadura - um de cada extremidade das parcelas experimentais.

Todos os tanques foram preenchidos com solo autoclavado até $0,15 \mathrm{~m}$ da borda. Foi usado solo, classificado como Latossolo Vermelho-Amarelo distrófico típico, fase cerrado e textura argiolosa (56\% argila; $37 \%$ silte; $7 \%$ areia), coletado no Campo Experimental da Embrapa Hortaliças, Brasília, Distrito Federal, na camada até 0,40 m de profundidade. Antes de autoclavado, o solo foi destorroado, peneirado e adubado. Durante o processo de enchimentos das parcelas o solo foi compactado levemente de forma a se obter da densidade global do solo em condições normais de cultivo à campo $\left(1,05 \mathrm{~g} \mathrm{~cm}^{-3}\right)$.

A análise química do solo autoclavado, realizada pelo Laboratório de Fertilidade de Solos da Embrapa Hortaliças, indicou: $\mathrm{pH}=5,9$ (água 1:2,5); $\mathrm{P}=16,0 \mathrm{mg} \mathrm{dm}{ }^{-3} ; \mathrm{K}=103 \mathrm{mg}$ $\mathrm{dm}^{-3} ; \mathrm{Na}=5 \mathrm{mg} \mathrm{dm}{ }^{-3}$ (Mehlich-1); $\mathrm{Ca}=5,8 \mathrm{cmol}_{\mathrm{c}} \mathrm{dm}^{-3} ; \mathrm{Mg}=2,6 \mathrm{cmol}_{\mathrm{c}} \mathrm{dm}^{-3} ; \mathrm{Al}=0,00$ $\operatorname{cmol}_{\mathrm{c}} \mathrm{dm}^{-3}(\mathrm{KCl} 1 \mathrm{~N}) ; \mathrm{H}+\mathrm{Al}=1,8 \mathrm{cmol}_{\mathrm{c}} \mathrm{dm}^{-3}$ (acetato de cálcio a $\mathrm{pH} 7,0$ ); e matéria orgânica (oxidação via úmida) $=33,7 \mathrm{~g} \mathrm{dm}^{-3}$.

A retenção de água do solo ( $\theta, \%$ vol.), no intervalo de tensão de água $(\Psi \mathrm{m})$ de 5 a $1.500 \mathrm{kPa}$, foi determinada, pelo Laboratório de Irrigação da Embrapa Hortaliças, e ajustada à equação de van Genuchten (1980), produzindo a seguinte relação: 


$$
\theta_{\mathrm{a}}=22,6+\frac{(39,9-22,6)}{\left[1+\left(0,0583 \times \mathrm{T}_{\mathrm{m}}\right)^{1,8114}\right]^{0,549}} .
$$

(equação 1)

em que $\theta_{\mathrm{a}}$ é a umidade volumétrica atual do solo $\left(\mathrm{cm}^{3} \mathrm{~cm}^{-3}\right)$ e $\mathrm{T}_{\mathrm{m}}$ a tensão de água na matriz do solo $(\mathrm{kPa})$.

As parcelas dos tratamentos inoculados receberam inicialmente solo não inoculado até 0,40 m da borda, sendo a camada de $0,15 \mathrm{~m}$ acima preenchida com solo infestado com inóculo de $V$. dahliae. A camada de $0,10 \mathrm{~m}$ acima da camada com inóculo foi completada com solo não inoculado, tendo restado $0,15 \mathrm{~m}$ até a borda do tanque sem solo.

\section{Produção de inóculo de V. dahliae e inoculação do solo}

Para a inoculação do solo com V. dahliae foram utilizados os isolados Vert. 15 e Vert. 120, identificados como os mais agressivos da coleção micológica do Laboratório de Fitopatologia da Embrapa Hortaliças, conforme testes de patogenicidade descritos no capítulo anterior desta dissertação.

Os isolados de $V$. dahliae selecionados foram repicados em meio BDA + tetraciclina (500 ppm) e mantidos à temperatura ambiente para crescimento. Após sete dias, os micélios de quatro discos de $1 \mathrm{~mm}$ de diâmetro de cada isolado, com crescimento abundante de micélio, foram retirados e colocados em erlenmeyer contendo $100 \mathrm{~mL}$ de meio líquido BD. O meio de cultura foi deixado em agitador automático por quinze dias à temperatura ambiente para crescimento do fungo. Após este processo, filtrou-se a suspensão de esporo em gaze dupla e ajustou-se a concentração de inóculo, com emprego de um hemacitômetro, para 2×10 conídios/mL, segundo metodologia adaptada de Miranda et al. (2010).

Para facilitar a infecção homogênea do solo com o inóculo utilizou-se vermiculita. Seis erlenmeyers de 2,0 L, contendo $200 \mathrm{~g}$ de vermiculita enriquecida com meio líquido BD, 
na proporção $2,25 \mathrm{~mL} / \mathrm{g}$, foram autoclavados a $121^{\circ} \mathrm{C}$, por $30 \mathrm{~min}$. Em seguida, foram adicionados $40 \mathrm{~mL}$ do inóculo, na concentração de $2 \times 10^{6}$, a 500 g de vermiculita enriquecida. Esse composto foi mantido em recipiente plástico, à temperatura ambiente durante vinte dias, no Laboratório de Micologia da Universidade de Brasília, sendo agitado manualmente por alguns segundos a cada três dias para uniformizar o crescimento do fungo.

O solo usado nas parcelas dos tratamentos inoculados - camada de 0,10-0,25 m abaixo da superfície do solo - foi infestado com $100 \mathrm{~g}$ de vermiculita contendo o fungo. A homogeneização foi obtida misturando-se o solo autoclavado e o composto de vermiculita em uma betoneira com capacidade de $40 \mathrm{~L}$ durante 5 minutos.

\section{Estabelecimento e condução das plantas}

Para a condução do experimento foi selecionado o híbrido Ciça por ser suscetível ao $V$. dahliae, ter uma boa base genética para as plantas permanecerem em desenvolvimento tempo suficiente para que o efeito dos tratamentos pudesse ser observado e por ser bastante difundido entre os produtores brasileiros.

O estabelecimento das plantas de berinjela nas parcelas foi realizado a partir de mudas produzidas na Embrapa Hortaliças em bandejas de 128 células. Foram usadas bandejas novas, substrato comercial e água de irrigação de poço semi-artesiano para garantir a produção de mudas livres de qualquer patógeno.

As mudas foram transplantadas com 30 dias - dia 26 de junho de 2014 - em solo previamente irrigado até condição de capacidade de campo. Foram usadas seis mudas por parcela, dispostas em duas fileiras de três plantas com espaçamento equidistante dentro da parcela. Aos 50 dias após o transplante foi eliminada, preferencialmente, a planta central de cada fileira, deixando-se quatro plantas por parcela. Tal estratégia visou garantir estande 
uniforme e maior uso inicial de água pelas plantas ainda pequenas, de forma a evitar que o intervalo entre regas fosse muito espaçado. Também visando a obtenção de estande e crescimento inicial de plantas uniformes, as regas foram iguais para todos os tratamentos durante a primeira semana após o transplante.

Os tratos culturais dispensados à cultura se resumiram na eliminação das brotações que surgiam abaixo da primeira bifurcação, na haste principal da planta (Ribeiro et al., 1998). Para o controle de insetos-praga, sobretudo de mosca branca (Bemisia tabaci), foi aplicado semanalmente inseticida sistêmico do grupo Neonicotinóide. Não houve necessidade do uso de qualquer tipo de produto para o controle de doenças. Com o desenvolvimento das plantas e em razão das mesmas estarem acima da superfície do terreno, foi necessário o prender alguns ramos laterais à estrutura de cobertura das parcelas experimentais.

\section{Manejo da água de irrigação}

As irrigações das parcelas foram realizadas manualmente utilizando-se um regador plástico de $10 \mathrm{~L}$ com crivo fino na ponta. O volume de água aplicado em cada parcela era medido previamente com auxílio de Becker $(5$ L) e proveta $(1$ L) graduados.

Após a diferenciação dos tratamentos de irrigação, a partir da segunda semana após o transplante, as irrigações foram estabelecidas com base na leitura diária, realizada entre 8h e 10h, de sensores tensiométricos (Marouelli, 2008), instalados nos tratamentos $\mathrm{AD}_{90 \%} \mathrm{e}$ $\mathrm{AD}_{55 \%}$, e Irrigas ${ }^{\circledR}$ (Marouelli \& Calbo, 2009), instalados no tratamento $\mathrm{AD}_{20 \%}$. No tratamento $\mathrm{AD}_{20-90 \%}$ foi utilizado sensores Irrigas ${ }^{\circledR}$ durante o estádio vegetativo, quando a água disponível no solo atingia $20 \%$, e tensiômetros durante o estádio de produção, quando a água disponível no solo atingia $90 \%$. 
Em cada parcela foram instalados dois sensores (tensiômetros ou Irrigas ${ }^{\circledR}$ ) a uma profundidade equivalente a $40-50 \%$ da profundidade efetiva do sistema radicular da cultura e entre 0,10 m e 0,20 m de distância da planta (Marouelli \& Calbo, 2009; Marouelli, 2008), sendo a menor distância durante os primeiros 50 dias após o transplante. Os sensores foram instalados inicialmente a $0,05 \mathrm{~m}$ e aprofundados até $0,20 \mathrm{~m}$, conforme o crescimento das raízes.

Como os sensores usados medem tensão matricial de água no solo, utilizou-se a equação 1 para determinação das tensões-limite de água no solo associadas às percentagens de água disponível de 90\%, 55\% e 20\%, que foram iguais a $8 \mathrm{kPa}, 45 \mathrm{kPa}$ e $275 \mathrm{kPa}$, respectivamente.

As leituras dos tensiômetros foram realizadas com tensímetro digital de punção, com precisão de 0,01 kPa. Neste caso, as regas eram irrigadas sempre que a média das leituras de todos os tensiômetros instalados nas parcelas de um mesmo tratamento fosse igual ou maior que a tensão-limite de água no solo associada ao tratamento. Como as leituras dos sensores eram realizadas apenas uma vez por dia, irrigava-se também caso a média das leituras dos tensiômetros fosse $10 \%$ inferior ao valor da tensão-limite. Leituras discrepantes eram desconsideradas e tensiômetros com problemas eram revisados ou substituídos.

Como não existem Irrigas ${ }^{\circledR}$ comerciais com tensão de referência acima de $40 \mathrm{kPa}$ (Marouelli \& Calbo, 2009), os sensores usados para indicar quando irrigar as plantas de berinjela nos tratamentos $\mathrm{AD}_{20 \%}$ e $\mathrm{AD}_{20-90 \%}$ foram produzidos artesanalmente usando hastes tubulares de carbeto de silício, fabricados pela Tecnicer Tecnologia Cerâmica, com 22 mm de diâmetro. A porosidade dos tubos permitiu produzir sensores com tensão de referência entre $220 \mathrm{kPa}$ e $250 \mathrm{kPa}$. Como a quantidade de água entre as tensões de $220 \mathrm{kPa}$ e $275 \mathrm{kPa}$ é pequena no solo usado no experimento plantas $\left(0,04 \mathrm{~mm} \mathrm{~cm}^{-1}\right)$, podendo ser usada pelas 
plantas em poucas horas, conforme equação 1, os sensores Irrigas ${ }^{\circledR}$ usados permitiram determinar o momento de irrigar os tratamentos com 90\% de água disponível com precisão similar à dos tensiômetros nos tratamentos $\mathrm{AD}_{90 \%}$ e $\mathrm{AD}_{55 \%}$ (Paschold \& Mohammed, 2003). As irrigações eram realizadas sempre que pelo menos três de seis Irrigas® instalados nas parcelas de um mesmo tratamento indicasse que a tensão de água no solo havia ultrapassado a tensão de referência dos sensores (Marouelli \& Calbo, 2009).

Estabelecido o momento de se irrigar, o volume de água aplicado em cada parcela de um mesmo tratamento foi calculado pela seguinte equação (Marouelli et al., 2011):

$$
\begin{gathered}
\mathrm{LRN}=\left(\theta_{\mathrm{CC}}-\theta_{\mathrm{TI}}\right) \times \mathrm{Z}_{\mathrm{r}} \\
\text { (equação 2) }
\end{gathered}
$$

em que LRN é a lâmina de água real necessária à irrigação $(\mathrm{mm}), \theta_{\mathrm{CC}}$ a umidade volumétrica do solo correspondente à capacidade de campo $\left(\mathrm{cm}^{3} \mathrm{~cm}^{-3}\right), \theta_{\mathrm{UI}}$ é umidade volumétrica do solo correspondente à tensão de irrigação $\left(\mathrm{cm}^{3} \mathrm{~cm}^{-3}\right)$ e $\mathrm{Z}_{\mathrm{r}}$ a profundidade efetiva do sistema radicular da cultura $(\mathrm{mm})$.

A umidade do solo correspondente à capacidade de campo foi determinada pela equação 1, considerando-se a tensão de $5 \mathrm{kPa}$, tendo sido igual a $0,379 \mathrm{~cm}^{3} \mathrm{~cm}^{-3}$. Similarmente, as umidades do solo correspondentes às tensões de irrigação de $8 \mathrm{kPa}\left(\mathrm{D}_{90 \%}\right)$, $45 \mathrm{kPa}\left(\mathrm{AD}_{55 \%}\right)$ e $275 \mathrm{kPa}\left(\mathrm{AD}_{20 \%}\right)$ foram determinadas iguais a $0,369 \mathrm{~cm}^{3} \mathrm{~cm}^{-3}, 0,327 \mathrm{~cm}^{3}$ $\mathrm{cm}^{-3}$ e $0,288 \mathrm{~cm}^{3} \mathrm{~cm}^{-3}$, respectivamente. A tensão de $5 \mathrm{kPa}$ para determinação de $\theta_{\mathrm{CC}}$ foi considerada em função do solo utilizado ser típico de Cerrado, caracterizado pela elevada estabilidade estrutural em decorrência da atuação dos óxidos de alumínio e de ferro e da matéria orgânica (Marouelli et al., 2011).

A profundidade efetiva do sistema radicular, que representa a camada de solo onde se concentram $80 \%$ das raízes, foi considerada igual a $100 \mathrm{~mm}$ até $10^{\circ}$ dia após o transplante, 
$150 \mathrm{~mm}$ até $30^{\circ}$ dia, $200 \mathrm{~mm}$ até o início de floração, $300 \mathrm{~mm}$ durante a floração e $400 \mathrm{~mm}$ durante o estádio de produção, conforme sugerido por Marouelli et al. (2014a) para o mesmo tipo de solo usado no experimento.

Como as irrigações foram realizadas manualmente com regador, a quantidade de água aplicada em cada parcela, considerando-se eficiência de irrigação de $100 \%$, foi determinada em volume, a partir da LRN determinada na equação 2 e na área da parcela experimental $\left(0,64 \mathrm{~m}^{2}\right)$, usando-se a seguinte equação:

$$
\begin{gathered}
\mathrm{V}_{\mathrm{a}}=0,64 \times \mathrm{LRN} \\
(\text { equaçãa } 3)
\end{gathered}
$$

em que $\mathrm{V}_{\mathrm{a}}$ é o volume de água aplicada por parcela experimental (L).

Na Tabela 2.1 é apresentado o volume de água aplicada em cada parcela experimental em função percentagem de água disponível no solo, considerada como limite para realização das irrigações, e profundidade efetiva do sistema radicular da cultura.

No dia anterior ao término do experimento irrigou-se todas as parcelas de forma que o solo retornasse até a condição de capacidade de campo na camada equivalente a profundidade efetiva do sistema radicular da cultura.

\section{Variáveis avaliadas}

Foram avaliadas as seguintes variáveis: temperatura do ar e do solo, número total de irrigações realizadas, volume total de água aplicado, incidência e severidade da doença, altura de plantas, altura de escurecimento do xilema da planta, porcentagem de escurecimento do xilema da planta e massa seca da parte aérea de plantas.

O número de irrigações e o volume de água aplicado, que representaram as regas realizadas do transplante das mudas até o término do experimento, foram determinados por 
tratamentos, pois todas as parcelas de um mesmo tratamento eram irrigadas no mesmo dia com a mesma quantidade de água.

$\mathrm{O}$ monitoramento da temperatura e da umidade relativa do ar junto às plantas e da temperatura do solo foi realizado com Data Loggers WatchDog, modelo 1450 (Spectrum Tecnologies, Inc.), em uma das repetições de cada tratamento. Os Data Loggers, com sensores internos de temperatura (precisão $\pm 0,6{ }^{\circ} \mathrm{C}$ ) e umidade relativa (precisão $\pm 3 \%$ UR) do ar, foram instalados dentro de mini abrigo próprio a $0,30 \mathrm{~m}$ de altura, junto à lateral do tanque. Os sensores de temperatura de solo (precisão $\pm 0,6^{\circ} \mathrm{C}$ ) foram instalados a $0,05 \mathrm{~m}$ de profundidade e a 0,10 m de distância da planta. As leituras forma realizadas com intervalo de $30 \mathrm{~min}$.

A incidência de murcha de verticílio foi avaliada durante todo o ciclo de cultivo da cultura, tendo sido calculada pela porcentagem de plantas sintomáticas em relação ao total de plantas na parcela experimental. Todas as plantas do experimento foram avaliadas no mesmo dia por um mesmo avaliador, tendo sido considerada como sintomática qualquer planta com sintoma visual característico da doença (Kurozawa et al., 2005) em pelo menos uma das folhas.

A severidade da doença foi determinada pela equação 4, conforme McKynney (1923), usando adaptação da escala de notas proposta por Miranda et al. (2010), onde: 0 = plantas assintomáticas; 1 plantas com ausência de sintomas foliares como murcha $\mathrm{e}$ amarelecimento, mas com presença de escurecimento vascular; 2 = plantas que apresentam folhas com amarelecimento, necrose atingindo seu terço inferior; 3 = plantas com murcha ou subdesenvolvimento, com amarelecimento e necrose atingindo seu terço superior; 4 = colapso e morte da planta. Todas as plantas foram avaliadas por um mesmo avaliador aos 200 dias após o transplante. 


$$
\begin{gathered}
\mathrm{S}_{\mathrm{EV}}=100 \times \sum\left(\frac{\mathrm{f} \times \mathrm{v}}{\mathrm{n} \times \mathrm{x}}\right) . \\
(\text { equação } 4)
\end{gathered}
$$

em que $S_{E V}$ é a severidade da doença (\%), “f” é o número de plantas com a mesma nota, "v" a nota observada, "n" o número total de plantas avaliadas e "x" a nota máxima da escala.

O experimento foi finalizado aos 202 dias após o transplante de mudas, quando todas as plantas foram retiradas para avaliações da altura da lesão provocada pela doença no xilema da planta e da massa seca da parte aérea de plantas. Antes de serem retiradas dos tanques, mediu-se a altura máxima de cada planta a partir do coleto e eliminaram-se todos os frutos existentes.

Após serem cortadas no coleto, as plantas receberam um corte longitudinal a partir do coleto até a base do pecíolo para medição da altura que a colonização do patógeno atingiu, por meio da observação visual do escurecimento do xilema. A porcentagem de escurecimento do xilema foi determinada pela relação entre altura de escurecimento do xilema e a altura da planta.

Todas as plantas de uma mesma parcela experimental foram posteriormente pesadas, em balança de precisão com capacidade máxima de $50 \mathrm{~kg}$ e erro instrumental de $10 \mathrm{~g}$, para determinação da massa total da parte aérea (caule, hastes e folhas). A porcentagem média de matéria seca de plantas foi determinada a partir da massa úmida e seca da parte aérea de oito plantas, sendo uma de cada tratamento - plantas mantidas em estufa a $60{ }^{0} \mathrm{C}$ até peso constante. A massa seca da parte aérea de plantas por parcela foi obtida multiplicando-se a massa total da parte aérea pela porcentagem de matéria seca.

Os dados obtidos foram submetidos à análise de variância padrão, conforme aplicável a delineamentos experimentais fatoriais, usando-se o teste "F", a 5\% de significância. Para 
comparação de médias das variáveis afetadas significativamente pelos níveis de água disponível no solo empregou-se o teste de Tukey, a 5\% de significância. 


\section{RESULTADOS}

Ao longo do período de condução do experimento foram realizadas 152 irrigações e aplicado um volume total de água de $662 \mathrm{~L}$ por tanque nos tratamentos $\mathrm{AD}_{90 \%}, 50$ irrigações e $532 \mathrm{~L}$ de água nos tratamentos $\mathrm{AD}_{55 \%}, 19$ irrigações e $292 \mathrm{~L}$ de água nos tratamentos $\mathrm{AD}_{20 \%} \mathrm{e}$ 53 irrigações e $435 \mathrm{~L}$ de água nos tratamentos $\mathrm{AD}_{20-90 \%}$. Assim, o turno de rega médio nos tratamentos $\mathrm{AD}_{90 \%}, \mathrm{AD}_{55 \%}, \mathrm{AD}_{20 \%}$ e $\mathrm{AD}_{20-90 \%}$ foi, respectivamente de 1,2 dias, 3,8 dias, 9,8 dias e 3,1 dias, sendo que o turno de rega no tratamento $\mathrm{AD}_{20-90 \%}$ foi de 11,6 dias no estádio vegetativo e de 1,6 dias no estádio de produção.

Não houve variação significativa dos dados médios de temperatura do solo (média de $20,7{ }^{\circ} \mathrm{C}$ ) temperatura do ar (média 22,3) e de e umidade relativa (média de 58,7\%) entre os diferentes tratamentos avaliados, pois as variações medidas foram inferiores à precisão dos sensores utilizados. A temperatura mínima do solo ao longo do ciclo teve média de $19,4{ }^{\circ} \mathrm{C}$ e a máxima média de $21{ }^{\circ} \mathrm{C}$ (Figura 2.1), enquanto média entre as temperaturas mínimas do ar foi de $18,0^{\circ} \mathrm{C}$ e máximas de $26,8^{\circ} \mathrm{C}$ (Figura 2.2). A umidade relativa média entre as mínimas diárias foi de 47,8\% e entre as máximas de 70,7\% (Figura 2.3).

Nos tratamentos $\mathrm{AD}_{90 \%}$ as parcelas com inóculo tiveram média de $20,6{ }^{\circ} \mathrm{C}$, enquanto parcelas sem inóculo, apresentaram média $0,3{ }^{\circ} \mathrm{C}$ menor. Para o tratamento $\mathrm{AD}_{55 \%}$ a média de $20,6{ }^{\circ} \mathrm{C}$ não variou em virtude da inoculação do solo. $\mathrm{O}$ tratamento $\mathrm{AD}_{20 \%}$ teve média de 21,0 ${ }^{\circ} \mathrm{C}$ nas parcelas inoculadas, mesma média medida nos $\mathrm{AD}_{20-90 \%}$ para solo sem inóculos, mas este apresentou media dos inoculados de $20,7{ }^{\circ} \mathrm{C}$, que representou $0,1^{\circ} \mathrm{C}$ a mais do que a média dos tratamentos controle de $\mathrm{AD}_{20 \%}$ (Figura 2.1).

Nenhuma das parcelas experimentais em solo não inoculado (tratamentos controle) apresentou qualquer incidência da doença ou lesão interna do xilema provocada por $V$. 
dahliae. Por outro lado, uma parcela experimental dos tratamentos $\mathrm{AD}_{55 \%}, \mathrm{AD}_{20 \%}$ e $\mathrm{AD}_{20-90 \%}$ em solo inoculado apresentaram 100\% de plantas assintomáticas. Para haver equivalência na análise, foi retirada do tratamento $\mathrm{AD}_{90 \%}$ a repetição com menor sintoma da doença. Assim, a análise estatística foi realizada considerando-se três repetições dos tratamentos controle e duas repetições dos tratamentos em solo inoculado.

A incidência e a severidade da doença foram nulas para todos os tratamentos em solo sem inoculação. Relativo à incidência da doença, verificou-se não ter havido interação significativa entre os fatores inoculação do solo e água disponível no solo, sendo que apenas o fator inoculação do solo apresentou efeito significativo sobre a incidência da doença, como esperado (Tabela 2.2). Por outro lado, houve interação significativa entre inoculação do solo e água disponível no solo para severidade. Pelo teste de Tukey, menor severidade foi verificada no tratamento AD20-90\% (21.8\%), não tendo havido diferença estatística entre os demais tratamentos (média de 55.2\%) (Tabela 2.3). A altura de plantas (média de 1.40m) não foi afetada significativamente pela condição de inoculação do solo e níveis de disponibilidade de água no solo avaliados, não tendo sido verificada interação significativa entre ambos os fatores (Tabela 2.4).

A análise estatística para altura de escurecimento do xilema de planta indicou a existência de interação significativa entre os fatores inoculação do solo e disponibilidade de água no solo (Tabela 2.5). As plantas cultivadas em sem inoculação não apresentaram qualquer lesão interna de xilema provocada pelo patógeno, independente dos tratamentos de irrigação. Nos tratamentos inoculados, por outro lado, verificou-se que a maior altura de escurecimento ocorreu no tratamento AD90\% (0.73 m), enquanto que os tratamentos AD2090\% (0.38 m) e AD20\% (0.44 m) apresentaram menor altura de lesão no xilema. A altura média da lesão no tratamento $\operatorname{AD55\% }(0.47 \mathrm{~m})$ não diferiu significativamente, pelo teste de Tukey, dos demais tratamentos conduzidos em solo inoculado. 
Diferentemente da altura de escurecimento do xilema, não houve efeito da disponibilidade de água no solo e sua interação com o fator inoculação do solo sobre a porcentagem de escurecimento do xilema (Tabela 2.6). Conforme esperado, a porcentagem de escurecimento do xilema da planta foi afetada significativamente pelo fator inoculação do solo. Enquanto nos tratamentos não inoculados a porcentagem de escurecimento foi igual a zero, nos tratamentos inoculados foi de $39.5 \%$.

Relativo à massa seca da parte aérea, a análise de variância indicou a existência de efeito significativo dos fatores inoculação do solo e disponibilidade de água no solo, não havendo interação significativa entre ambos os fatores (Tabela 2.7). A massa seca média entre tratamentos não inoculados foi de 728 g por parcela, enquanto nos tratamentos inoculados foi de 649 g. Dentre os tratamentos de irrigação avaliados, maior massa seca ocorreu no AD90\% (859 g) e menor nos tratamentos AD20\% (585.6 g) e AD55\% (631.8 g). A massa seca da parte aérea no tratamento AD20-90\% (707.5 g), não diferiu, pelo teste de Tukey, dos demais tratamentos, independentemente se em solo inoculado ou não. 


\section{DISCUSSÃO}

Para estudar o efeito da disponibilidade de água no solo na ocorrência de murcha de verticílio foram proporcionadas condições iguais em dois dos três vértices do "triângulo da doença": a) solo inoculado com patógeno virulento de forma idêntica em todas as parcelas experimentais que não as parcelas controle; b) cultivo de hospedeira suscetível de berinjela cv. Ciça - à $V$. dahliae. Para ocorrência da doença é necessário que o terceiro vértice do triângulo - ambiente favorável - atue concomitante com os demais. Exceto pela disponibilidade de água no solo, usada como indicador para definir quando e quanto irrigar, todas as demais variáveis de produção e climáticas foram mantidas constantes ao longo do ciclo de cultivo da berinjela. Assim, houve grande espectro de variação dos tratamentos de irrigação sobre o número total de irrigações realizadas (19 a 152) e o volume total de água aplicado (292 a $662 \mathrm{~L}$ por parcela).

As medições dos Data Loggers confirmaram não haver diferença de temperatura e umidade relativa do ar entre tratamentos. Assim, não houve favorecimento ao desenvolvimento do patógeno, ideal entre 22 e $26^{\circ} \mathrm{C}$ (Kurozawa et al., 2005), em relação a esta variável. Outra variável ambiental que pode influenciar a ocorrência e a severidade de doenças de solo, além do desenvolvimento de plantas, é a temperatura do solo (Gasparim et al., 2005). No presente estudo a temperatura do solo, avaliada a $0.05 \mathrm{~m}$ de profundidade, não foi afetada pelos tratamentos (média de $20,7^{\circ} \mathrm{C}$ ). Segundo Bergamaschi \& Guadagnin (1993), a amplitude de variação da temperatura do solo tende a ser menor quando maior a profundidade do solo. Desta forma, o único fator ambiental que efetivamente variou ao longo do presente trabalho foi a disponibilidades de água no solo.

Os tratamentos controle tiveram as mesmas disponibilidades de água no solo aplicadas à mesma hospedeira suscetível de berinjela em solo sem a presença do patógeno virulento. 
Como esperado, devido a um dos três vértices do "triângulo da doença" ser nulo, a incidência e severidade da doença, a altura e porcentagem de escurecimento do xilema de plantas foram nulas. Tais resultados indicam que não houve qualquer tipo de contaminação das parcelas dos tratamentos controle durante a condução do experimento. Adicionalmente, o contraste entre os tratamentos controles com os conduzidos em solo inoculados possibilita quantificar o efeito da ocorrência da doença no desenvolvimento das plantas de berinjela.

A incidência de doença nos tratamentos em solo inoculado não foi afetada significativamente pelos tratamentos de irrigação avaliados, mesmo tendo a incidência média de doença variado expressivamente - entre $50,0 \%$, no tratamento $\mathrm{AD}_{20-90 \%}$, e $87,5 \%$, no tratamento $\mathrm{AD}_{90 \%}$ (Tabela 2.2). A não significância do teste $\mathrm{F}(\mathrm{p}>0,05)$ deveu-se basicamente ao elevado coeficiente de variação observado $(\mathrm{CV}=121 \%)$. Valores elevados de coeficiente de variação em experimento avaliando efeito da irrigação sobre patógenos de solo, são reportados por Marouelli et al. (2005)

Similarmente, Bletsos et al. (1999) não verificaram efeito significativo da umidade do solo na incidência de murcha de verticílio em plantas de berinjela transplantadas em solo inoculados com $V$. dahliae. Os autores obtiveram, no entanto, $100 \%$ de incidência da doença ao final do ciclo de produção da cultura, independentemente da umidade do solo avaliada.

Quanto à severidade da doença, os tratamentos $\mathrm{AD}_{90 \%}$ (alta umidade), $\mathrm{AD}_{55 \%}$ (umidade moderada) e $\mathrm{AD}_{20 \%}$ (baixa umidade), nos quais foram mantidos o mesmo regime de irrigação ao longo de todo o ciclo de cultivo da berinjela, não apresentaram diferenças significativas entre si .Era de se esperar, segundo Cook \& Papendick (1972) e Schnathorst (1981), que a maior disponibilidade de água no solo favorecesse a doença e a disseminação do patógeno nos tecidos da planta, em razão da maior absorção e translocação de água no xilema das plantas mantidas em solos mais úmidos, o que não ocorreu no presente experimento. 
Redução significativa na severidade de murcha de verticílio no presente experimento foi observada, no entanto, no tratamento $\mathrm{AD}_{20-90 \%}$, no qual as plantas foram irrigadas com déficit de água durante o estádio vegetativo (20\% de água disponível) e com suprimento de água plena durante o estádio de produção (90\% de água disponível). A menor disponibilidade de água no solo durante o estádio vegetativo da berinjela provavelmente retardou o processo de infecção da doença. Posteriormente, com a planta apenas parcialmente colonizada pelo patógeno, a maior disponibilidade de água no solo a partir do estádio de produção contrabalancearia a obstrução parcial do xilema ao transportar de água do solo para a parte aérea das plantas (Lopes et al., 2006).

$\mathrm{O}$ déficit de água no tratamento $\mathrm{AD}_{20 \%}$ foi mantido durante todo o estádio vegetativo e de produção, diferentemente do tratamento $\mathrm{AD}_{20-90 \%}$. Assim, apesar da baixa disponibilidade de água acarretar no provável atraso no processo infeccioso durante o estádio vegetativo e o não favorecimento do processo de colonização do patógeno durante o estádio de produção, Boyer (1995) indica que esse estresse hídrico pode aumentar a susceptibilidade da hospedeira ao patógeno, diminuindo a atividade fotossintética e afetando a síntese de metabólitos e enzimas importantes na expressão da resistência da planta.

Em estudo análogo na cultura da batata, Cappaert et al. (1994) verificaram que o excesso de umidade no solo até a fase de formação de tubérculo aumentou em $22 \%$ a ocorrência de murcha de verticílio $(V$. dahliae) em relação aos tratamentos que tiveram a irrigação deficitária durante o estádio pré-tuberização, independentemente da quantidade de água a partir do estádio de tuberezação. Irrigar com déficit moderado durante estádio vegetativo tem sido recomendado na produção de hortaliças, sobretudo daquelas do tipo fruto e tubérculo, como estratégia de manejo para minimizar a ocorrência de doenças causadas por patógenos de solo e maior aprofundamento radicular, sem causar redução significativa de 
produtividade (Marouelli \& Guimarães, 2006; Marouelli et al., 2014a; Marouelli et al., 2014b).

Não houve diferença significativa na altura de plantas em função da disponibilidade de água no solo e na inoculação do solo. Bletsos et al. (1999) verificaram que a altura de plantas de berinjela cultivadas no campo foi influenciada pelo fator inoculação, mas não pela frequência de irrigação. Porém vale destacar que em razão do presente experimento ter sido conduzido em tanques de concreto sob cobertura semitransparente. A cultura da berinjela apresenta tolerância moderada à seca e sistema radicular bem desenvolvido (Marouelli et al., 2014), desta forma, o concreto pode ter impedido o crescimento ótimo de raízes, e o crescimento das plantas pode ter sido limitado pela cobertura existente, o que justifica parcialmente a não resposta significativa da altura das plantas aos fatores inoculação do solo e água disponível no solo.

Altura de escurecimento do xilema provocado pela colonização de $V$. dahliae nas plantas de berinjela cultivadas em solo inoculado foi reduzida significativamente quanto menor a porcentagem de água disponível de água no solo usada como critério para indicar quando irrigar. Pelo teste de Tukey, no entanto, maior altura de escurecimento ocorreu no tratamento $\mathrm{AD}_{90 \%} \mathrm{e}$ menor altura nos tratamentos $\mathrm{AD}_{20-90 \%} \mathrm{e} \mathrm{AD}_{20 \%}$. A altura de escurecimento no tratamento $\mathrm{AD}_{55 \%}$ não diferiu significativamente dos demais. Os resultados de altura de escurecimento do xilema diferem substancialmente daqueles verificados para incidência e severidade da doença, sobretudo no que se refere aos tratamentos de irrigação aplicados de forma contínua durante os estádios vegetativo e de produção $\left(\mathrm{AD}_{90 \%}, \mathrm{AD}_{550 \%}\right.$.e $\left.\mathrm{AD}_{20 \%}\right)$. Estão, no entanto, de acordo com Cook \& Papendick (1972) e Schnathorst (1981), que relatam que a menor disponibilidade de água no solo desfavorece a disseminação do patógeno nos tecidos da planta. Diferentemente da incidência e da severidade da doença variáveis quantificadas a partir de fatores qualitativos, sintomas visuais da doença nas folhas - 
a altura de escurecimento indica, quantitativamente, a lesão efetivamente causada no xilema da planta. Assim, a altura de escurecimento provocado pela colonização do patógeno no xilema provavelmente seja uma variável que pode ser adicionada no cálculo de índice de doença.

Diferentemente da altura de escurecimento do xilema de plantas, a porcentagem de escurecimento do xilema não foi afetada significativamente pelos tratamentos de irrigação, mesmo tendo a porcentagem de escurecimento variado de $27,5 \%\left(\mathrm{AD}_{20-90 \%}\right)$ a $55,1 \%\left(\mathrm{AD}_{90 \%}\right)$ (Tabela 2.7). Apesar da expressiva amplitude de variação, a não existência de diferenças estatísticas entre os níveis de água disponível no solo deve-se, dentre outros fatores, ao coeficiente de variação para porcentagem de escurecimento (61\%) ter sido consideravelmente maior que para altura de escurecimento (40\%), associado ao grau de liberdades do resíduo experimental ter sido relativamente baixo. Outro aspecto que pode ter contribuído para a existência de respostas distintas entre porcentagem e altura de escurecimento pode estar associado à altura de plantas ter sido limitada pela cobertura existente sobre as parcelas experimentais. Adicionalmente, quando a avaliação foi realizada, aos 200 dias, o crescimento de plantas já estava praticamente estagnado devido à limitação da cobertura, enquanto a colonização tende a aumentar progressivamente (Reis \& Boiteux, 2006). Assim, seria de se esperar que a diferença de resposta da lesão no xilema provocada pelo patógeno, sobretudo quando expressa em termos de porcentagem de escurecimento, entre tratamentos de irrigação em solo inoculado com $V$. dahliae diminuísse - após atingir uma diferença máxima entre tratamentos - à medida que o ciclo de cultivo da berinjela avançasse.

Dentre os indicadores utilizados para avaliação da relação entre disponibilidade de água no solo e murcha de verticílio (incidência de doença, severidade de doença, altura de escurecimento do xilema e porcentagem de escurecimento do xilema), altura de escurecimento do xilema foi aquele que possivelmente expressou quantidade de infecção da 
doença em plantas de berinjela com maior precisão. Isto em razão do indicador avaliar de forma quantitativa a exata extensão da lesão provocada pela colonização de $V$. dahliae no xilema das plantas. Segundo Tofoli et al. (2013), a lesão provocada no xilema limita a absorção de água e nutrientes do solo pelas raízes e translocação na planta e, consequentemente, a produtividade de frutos. Os indicadores incidência e severidade de doença, por outro lado, são baseados na avaliação qualitativa de sintomas visuais da doença nas folhas, sintomas estes que se manifestam em decorrência das lesões provocadas no xilema e que podem ser mais ou menos intensos em função do nível de déficit hídrico que as plantas são submetidas e da magnitude de obstrução do xilema da planta pela colonização do patógeno (Mcelrone et al., 2001).

De forma distinta ao verificado para severidade de doença e altura de escurecimento do xilema de plantas, não houve interação significativa entre os fatores inoculação do solo e disponibilidade de água no solo para massa seca da parte aérea de plantas. Independente se cultivadas em solo com ou sem inoculação, a massa seca da parte aérea foi reduzida significativamente quando maior o déficit de água a que as plantas foram submetidas, não tendo havido diferenças, pelo teste de Tukey, entre os tratamentos $\mathrm{AD}_{55 \%}$ e $\mathrm{AD}_{20 \%}$. Já a massa seca de plantas irrigadas com déficit durante o estádio vegetativo e sem déficit durante o estádio de produção $\left(\mathrm{AD}_{20-90 \%}\right)$ não diferiu dos demais tratamentos de irrigação. Por outro lado, plantas cultivadas em solo inoculado apresentaram redução média de $11 \%$ na massa seca em relação às plantas cultivadas em solo sem inoculação, indicando que a ocorrência de murcha de verticílio prejudicou significativamente o crescimento vegetativo das plantas de berinjela. Similarmente ao verificado no presente estudo, Sanogo et al. (2008) também constataram que a massa seca da parte aérea da cultura do pimentão (Capsicum annuum L.) não foi afetada pela interação entre os fatores inoculação com $V$. dahliae e inundação do solo, mas apenas pelo efeito isolado dos fatores. 
Apesar da complexidade da interação da água com patógenos de solo, constatada pela variabilidade e divergência de resultados existentes na literatura e anteriormente apresentados. Os resultados indicam que o manejo da água de irrigação, sobretudo ao se reduzir a quantidade de água aplicada durante o estádio vegetativo da cultura, é uma estratégia eficaz para diminuir a severidade de murcha de verticílio em berinjela, sem acarretar redução significativa no crescimento vegetativo. 


\section{CONCLUSÕES FINAIS}

Genótipos das espécies Solanum melongena e Solanum stramonifolium têm potencial para serem utilizados em programa de melhoramento genético para resistência ao Verticillium dahliae e, também, como porta-enxerto.

O déficit hídrico durante e a plena disponibilidade de água durante todo o ciclo da cultura, não foram capazes de reduzir a severidade da doença, porém maior disponibilidade de água provocou maior altura de colonização do xilema, assim como maior produção de massa seca da planta.

O manejo da irrigação com redução da disponibilidade de água no solo no estádio vegetativo e fornecimento adequado no estádio reprodutivo, é eficaz para diminuir a severidade da murcha de verticílio em solos com a presença do patógeno, sem reduzir significativamente a produção de massa seca da planta. 


\section{REFERÊNCIAS}

AGRIOS, G. N. 2005. Plant Pathology. 5ed. Burlington - USA. Elsevier Academy Press.

ARBOGAST, M.; POWELSON, M. L.; CAPPAERT, M. R.; WARTRUD, L. S. 1999. Response of six potato cultivars to amount of applied water and Verticillium dahliae. Phytopathology 89(9): 782-788.

BERGAMASCHI, H. \& GUADAGNIN, M. R. 1993. Modelos de ajuste para médias de temperatura do solo, em diferentes profundidades. Revista Brasileira de Agrometeorologia 1(1): 95-99.

BLETSOS, F. A.; THANASSOULOPOULOS, C. C.; ROUPAKIAS, D. G. 2003. Effect of grafting on growth, yield, and verticillium wilt of eggplant. Hortscience 36(2): 183-186.

BOYER, J. S. 1995. Biochemical and biophysical aspects of water deficits and the predisposition to diseae. Annual Review of Phytopathology 33: 251-274.

CAPPAERT, M. R.; POWELSON, M. L.; CHRISTENSEN, N. W.; STEVENSON, W. R.; ROUSE, D.I. 1994. Assesment of irrigation as a method of managing potato early dying. Phytopathology 84(8): 792-800.

COOK. R. J. \& PAPENDICK, R. I. 1972. Influence of water potencial of soils and plants on root disease. Annual Review of Phytopathology 10: 349-374.

FILGUEIRA, F. A. R. 2003. Cultura da berinjela. p. 312-320. IN: Filgueira, F. A. R. Solanáceas: agrotecnologia moderna na produção de tomate, batata, pimentão, pimenta, berinjela e jiló. 1ed. UFLA.

GASPARIM, E.; RICIERI, R. P.; SILVA, S. DE L.; DALLACORT, R.; GNOATTO, E. Temperatura no perfil do solo utilizando duas densidades de cobertura e solo nu. 2005. Acta Scientiarum Agronomy 27(1): 107-115.

JEFFERSON, P. G.; GOSSEN, B. D. 2002. Irrigation increases verticillium wilt incidence in a susceptible alfalfa cultivar. Plant Disease 86(6): 588-592.

KUROZAWA, C.; PAVAN, M.A.; KRAUSE-SAKATE, R. 2005. Doenças das Solanáceas. p. 589-596 IN: Kimati, H.; Amorim, L.; Rezende, J.A.M.; Bergamini Filho, A.; Camargo, L.E.A. Manual de Fitopatologia - volume 2 - Doenças de Plantas Cultivadas. 4ed. Agronômica Ceres.

LAHKIM-TSOR, L.; HAZANOVSKY, M.; MORDECHI-LEBIUSH, S.; SIVAN, S. 2001. Aggressiveness of Verticillium dahliae isolates from different vegetative compatibility groups to potato and tomato. Plant Pathology 50(4): 477-482.

LOPES, C. A.; MAROUELLI, W. A.; CAFÉ-FILHO, A. C. 2006. Associação da irrigação com doenças de hortaliças. Revisão Anual de Patologia de Plantas 14: 151-179. 
MADEIRA, N. R.; REIFSCHNEIDER, F. J. B.; GIORDANO, L. B. 2008. Contribuição portuguesa à produção e ao consumo de hortaliças no Brasil: uma revisão histórica. Horticultura Brasileira 26(4): 428-432.

MAROUELLI, W. A. 2008. Tensiômetros para o controle de irrigação em hortaliças. Brasília: Embrapa Hortaliças. 15p. (Circular Técnica 57).

MAROUELLI, W. A.; BRAGA, M. B.; SILVA, H. R., COSTA, C. S. 2014a. Irrigação na cultura da berinjela. Brasília: Embrapa Hortaliças. 24 p. (Circular Técnica 135).

MAROUELLI, W. A.; CALBO, A. G. 2009. Manejo de irrigação em hortaliças com sistema irrigas®.Brasília: Embrapa Hortaliças. 16p. (Circular Técnica 69).

MAROUELLI, W. A.; GUIMARÃES, T. G. 2006. Irrigação na cultura da batata. Itapetininga: Associação Brasileira da Batata. 66p.

MAROUELli, W. A.; LAGE, D. A. C.; BRAGA, M. B. 2014B. Irrigação da cultura do tomateiro orgânico: enfoque no manejo de doenças e de insetos-praga. Brasília: Embrapa. $107 \mathrm{p}$.

MAROUELLI, W. A.; LOPES, C. A.; SILVA, W. L. C. 2005. Incidência de murchabacteriana em tomate para processamento industrial sob irrigação por gotejamento e aspersão. Horticultura Brasileira 23(2): 320-323.

MAROUElli, W. A.; OLIVEIRA, Á. S.; COELHO, E. F.; NOGUEIRA, L. C.; SOUSA, V. F. 2011. Manejo da água de irrigação. In: Sousa, V. F.; Marouelli, W. A.; Coelho, E. F.; Pinto, J. M.; Coelho Filho, M. A. (Ed.). Irrigação e fertirrigação em fruteiras e hortaliças. Brasília: Embrapa Informação Tecnológica. p. 157-232.

MCKINNEY, H. H. 1923. Influence of soil temperature and moisture on infection of wheat seedlings by Helminthosporium sativum. Journal of Agricultural Research 26(5): 195-217.

MCELRONE, A. J.; SHERALD, J. L.; FORSETH, I. N. 2001. Effects of water stress on symptomatology and growth of Parthenocissus quinquefolia infected by Xylella fastidiosa. Plant Disease 85(11): 1160-1164.

MIRANDA, B. E. C DE; BOITEUX, L. S.; CRUZ, E. M.; REIS, A. 2010. Fontes de resistência em acessos de Solanum (secção Lycopersicon) a Verticillium dahliae raças 1 e 2 . Horticultura Brasileira 28(4): 458-465.

NAIK, M. K.; RANI, G. S. D.; PRASADI, R. D.; PATIL, M. B.; SEN, B. 2008. An overview of soil borne plant pathogens. p. 1-33. IN: Advances In Soil Borne Plant Diseases. 1ed. New India Publishing Agency.

PASCHOLD, P.J.; MOHAMMED, A. 2003. Irrigas ${ }^{\circledR}$ - a new simple soil moisture sensor for irrigation scheduling. Journal of Applied Irrigation Science 38. p.22-28. 
PUNYAWARDENA, B. V. R. \& YAPA, L. G. G. 1990. Effect of soil compaction on potassium uptake, growth and yield of corn (Zea mays L). IN: Proceeding International Agricultural Engineering Conference and Exhibition, Bangkok, Thailand. v. 3. pp.1173-1184.

REIS, A.; BOITEUX, L. S. 2006. Murcha-de-verticillium: um sério problema para o cultivo de hortaliças no Brasil. Brasília: Embrapa-CNPH, 11p. (Circular Técnica 40).

REIS, A.; BOITEUX, L. S.; LOPES, C. A. 2011. Doenças da berinjela no Brasil. Brasília: Embrapa Hortaliças. 8p. (Circular Técnica 97).

RIBEIRO, C. S. C. DA; BRUNE, S.; REIFSCHNEIDER, F. J. B. 1998. Cultivo da berinjela (Solanum melongena L.). Brasília: Embrapa-CNPH, 23p. (Embrapa Hortaliças, Instruções Técnicas, 15).

SANOGO, S.; EL-SEBAI, O. I.; SANDERSON, R. 2008. Severity of verticillium wilt, plant growth, and spectral reflectance indices of chili peper under periodic flooding and noflooding conditions. HortScience 43(2): 414-419.

SCHNATHORST, W. C. 1981. Lifecycle and epidemiology of Verticillium. pp.81-11. IN: Fungal wilt diseases of plants. M.E. Mace, A. A. BeIl \& e.H. Beckman, eds. Acadernic Press, NY.

SILVA, R. A. 2006. Comportamento do tomate (Lycopersicon esculentum Mill.) aos indutores de resistência à seca. Dissertação de Mestrado. Escola Superior de Agricultura "Luiz de Queiroz”, São Paulo, Brasil.

TAMETTI, G. \& VALENTINO, D. 2001. Soil solarization: A useful tool for control of verticillium wilt and weeds in eggplant crops under plastic in the Po Valley. Journal of Plant Pathology 83(3): 173-180.

TOFOLI, J. G.; DOMINGUES, R. T.; FERRARI, J. T. 2013. Doenças fúngicas da oliva: sintomatologia, etiologia e manejo. Biológico 75(1): 53-61.

VAN GENUCHTEN, M. T. A closed-form equation for predicting the hydraulic conductivity of unsaturated soil. 1980. Soil Science Society American Journal 50: 288-291.

XIAO, C. L. \& SUBBARAO, K. V. 2000. Effects of irrigation and Verticillium dahliae on cauliflower root and shoot growth dynamics. Phytopathology 90(9): 995-1004.

YILDZ, A. \& BENLIOGLU, S. 2010. Effects of soil solarization and some amendments to control verticillium wilt in established olive orchards. African Journal of Biotechnology 9(40): 6660-6665. 
Tabela 2.1 - Volume de água (L) aplicado por irrigação em cada parcela experimental, conforme a água disponível no solo no momento da irrigação e a profundidade efetiva do sistema radicular da cultura. Brasília, 2015.

\begin{tabular}{cccccc}
\hline \multirow{2}{*}{ Água disponível (\%) } & \multicolumn{5}{c}{ Profundidade de raízes (m) } \\
\cline { 2 - 6 } & 0,10 & 0,15 & 0,20 & 0,30 & 0,40 \\
\hline 90 & 0,62 & 0,93 & 1,24 & 1,86 & 2,48 \\
55 & 3,32 & 4,97 & 6,63 & 9,95 & 13,26 \\
20 & 5,81 & 8,72 & 11,62 & 17,43 & 23,24 \\
\hline
\end{tabular}

Tabela 2.2 - Incidência de murcha de verticílio (\%) em plantas de berinjela, conforme a inoculação do solo (Inoc) com Verticillium dahliae e a porcentagem de água disponível no solo (AD) no momento da irrigação. Brasília, 2015.

\begin{tabular}{|c|c|c|c|c|c|}
\hline \multirow{2}{*}{ Inoculação } & \multicolumn{4}{|c|}{ Água disponível (\%) } & \multirow{2}{*}{ Média } \\
\hline & 90 & 55 & 20 & $20-90^{(1)}$ & \\
\hline Não & 0 & 0 & 0 & 0 & $0 \mathrm{a}$ \\
\hline Sim & 87,5 & 75,0 & 75,0 & 50,0 & $71,88 \mathrm{~b}$ \\
\hline Média & 35,0 & 30,0 & 30,0 & 20,0 & $C V=121 \%$ \\
\hline
\end{tabular}

(1) $20 \%$ durante o estádio vegetativo e $90 \%$ durante o estádio de produção.

Significância teste F: Fator Inoc <0,001; Fator $A D=0,124$; Interação Inc x $A D=0,124$.

Médias seguidas por letras distintas na coluna diferem entre si pelo teste $F(p<0,05)$.

Tabela 2.3 - Severidade da murcha de verticílio (\%) em plantas de berinjela, conforme a inoculação do solo (Inoc) com Verticillium dahliae e a porcentagem de água disponível no solo (AD) no momento da irrigação. Brasília, 2015.

\begin{tabular}{|c|c|c|c|c|c|}
\hline \multirow{2}{*}{ Inoculação } & \multicolumn{4}{|c|}{ Água disponível (\%) } & \multirow{2}{*}{ Média } \\
\hline & 90 & 55 & 20 & $20-90^{(1)}$ & \\
\hline Não & 0,0 Ba & $0,0 \mathrm{Ba}$ & $0,0 \mathrm{Ba}$ & $0,0 \mathrm{Ba}$ & 0,0 \\
\hline Sim & $59,4 \mathrm{Aa}$ & $50,0 \mathrm{Aa}$ & $56,2 \mathrm{Aa}$ & $21,8 \mathrm{Ab}$ & 46,9 \\
\hline Média & 23,7 & 20,0 & 22,5 & 8,7 & $C V=27,4 \%$ \\
\hline
\end{tabular}


Tabela 2.4 - Altura (m) de plantas de berinjela, conforme a inoculação do solo (Inoc) com Verticillium dahliae e a porcentagem de água disponível no solo (AD) no momento da irrigação. Brasília, 2015.

\begin{tabular}{|c|c|c|c|c|c|}
\hline \multirow{2}{*}{ Inoculação } & \multicolumn{4}{|c|}{ Água disponível (\%) } & \multirow{2}{*}{ Média } \\
\hline & 90 & 55 & 20 & $20-90^{(1)}$ & \\
\hline Não & 1,52 & 1,46 & 1,39 & 1,44 & 1,45 \\
\hline Sim & 1,35 & 1,43 & 1,19 & 1,45 & 1,35 \\
\hline Média & 1,45 & 1,45 & 1,31 & 1,44 & $C V=10 \%$ \\
\hline
\end{tabular}

(1) $20 \%$ durante o estádio vegetativo e $90 \%$ durante o estádio de produção.

Significância teste F: Fator Inoc =0,113; Fator $A D=0,316$; Interação Inc x $A D=0,646$.

Tabela 2.5 - Altura de escurecimento do xilema de plantas de berinjela $(\mathrm{m})$, provocada pela colonização de Verticillium dahliae, conforme a inoculação do solo (Inoc) com V. dahliae e a porcentagem de água disponível no solo (AD) no momento da irrigação. Brasília, 2015.

\begin{tabular}{cccccc}
\hline \multirow{2}{*}{ Inoculação } & \multicolumn{4}{c}{ Água disponível (\%) } & \multirow{2}{*}{ Média } \\
\cline { 2 - 5 } & 90 & 55 & 20 & $20-90^{(1)}$ & \\
\hline Não & $0,00 \mathrm{Ba}$ & $0,00 \mathrm{Ba}$ & $0,00 \mathrm{Ba}$ & $0,00 \mathrm{Ba}$ & 0,00 \\
Sim & $0,73 \mathrm{Aa}$ & $0,47 \mathrm{Aab}$ & $0,44 \mathrm{Ab}$ & $0,38 \mathrm{Ab}$ & 0,50 \\
\hline Média & 0,29 & 0,19 & 0,18 & 0,15 & $\mathrm{CV}=40 \%$ \\
\hline
\end{tabular}

(1) $20 \%$ durante o estádio vegetativo e $90 \%$ durante o estádio de produção.

Significância teste F: Fator Inoc < 0,001; Fator $A D=0,024$; Interação Inc x AD =0,024.

Médias seguidas por letras distintas maiúscula na coluna e minúscula na linha diferem entre si pelo teste $F$ e de Tukey, respectivamente $(p<0,05)$.

Tabela 2.6 - Porcentagem de escurecimento do xilema de plantas de berinjela, provocada pela colonização de Verticillium dahliae, conforme a inoculação do solo (Inoc) com V. dahliae e a porcentagem de água disponível no solo (AD) no momento da irrigação. Brasília, 2015.

\begin{tabular}{|c|c|c|c|c|c|}
\hline \multirow{2}{*}{ Inoculação } & \multicolumn{4}{|c|}{ Água disponível (\%) } & \multirow{2}{*}{ Média } \\
\hline & 90 & 55 & 20 & $20-90^{(1)}$ & \\
\hline Não & 0,0 & 0,0 & 0,0 & 0,0 & $0,0 \mathrm{a}$ \\
\hline Sim & 55,1 & 33,6 & 41,9 & 27,5 & $39,5 \mathrm{~b}$ \\
\hline Média & 22,0 & 13,4 & 16,7 & 10,1 & $C V=61 \%$ \\
\hline
\end{tabular}

${ }^{(1)} 20 \%$ durante o estádio vegetativo e $90 \%$ durante o estádio de produção.

Significância teste F: Fator Inoc $<0,001$; Fator $A D=0,203$; Interação Inc $\times A D=0,203$.

Médias seguidas por letras distintas na coluna diferem entre si pelo teste $F(p<0,05)$. 
Tabela 2.7 - Massa seca (g) da parte aérea de plantas de berinjela (exceto frutos), conforme a inoculação do solo (Inoc) com Verticillium dahliae e a porcentagem de água disponível no solo (AD) no momento da irrigação. Brasília, 2015.

\begin{tabular}{|c|c|c|c|c|c|}
\hline \multirow{2}{*}{ Inoculação } & \multicolumn{4}{|c|}{ Água disponível (\%) } & \multirow{2}{*}{ Média } \\
\hline & 90 & 55 & 20 & $20-90^{(1)}$ & \\
\hline Não & 925,7 & 666,0 & 625,2 & 693,3 & 728 a \\
\hline Sim & 759,2 & 580,6 & 526,2 & 728,7 & $649 \mathrm{~b}$ \\
\hline Média & $859,0 \mathrm{a}$ & $631,8 \mathrm{~b}$ & $585,6 \mathrm{~b}$ & $707,5 a b$ & $C V=12 \%$ \\
\hline
\end{tabular}

(1) $20 \%$ durante o estádio vegetativo e $90 \%$ durante o estádio de produção.

Significância teste F: Fator Inoc = 0,045; Fator $A D=0,003$; Interação Inc x AD =0,368.

Médias seguidas por letras distintas na coluna ou na linha diferem entre si pelo teste $F$ e de Tukey, respectivamente ( $p<$ 0,05). 
Figura 2.1 - Temperatura máxima, média e mínima diária do solo ao longo do ciclo de cultivo da berinjela, avaliada a $0,05 \mathrm{~m}$ de profundidade.

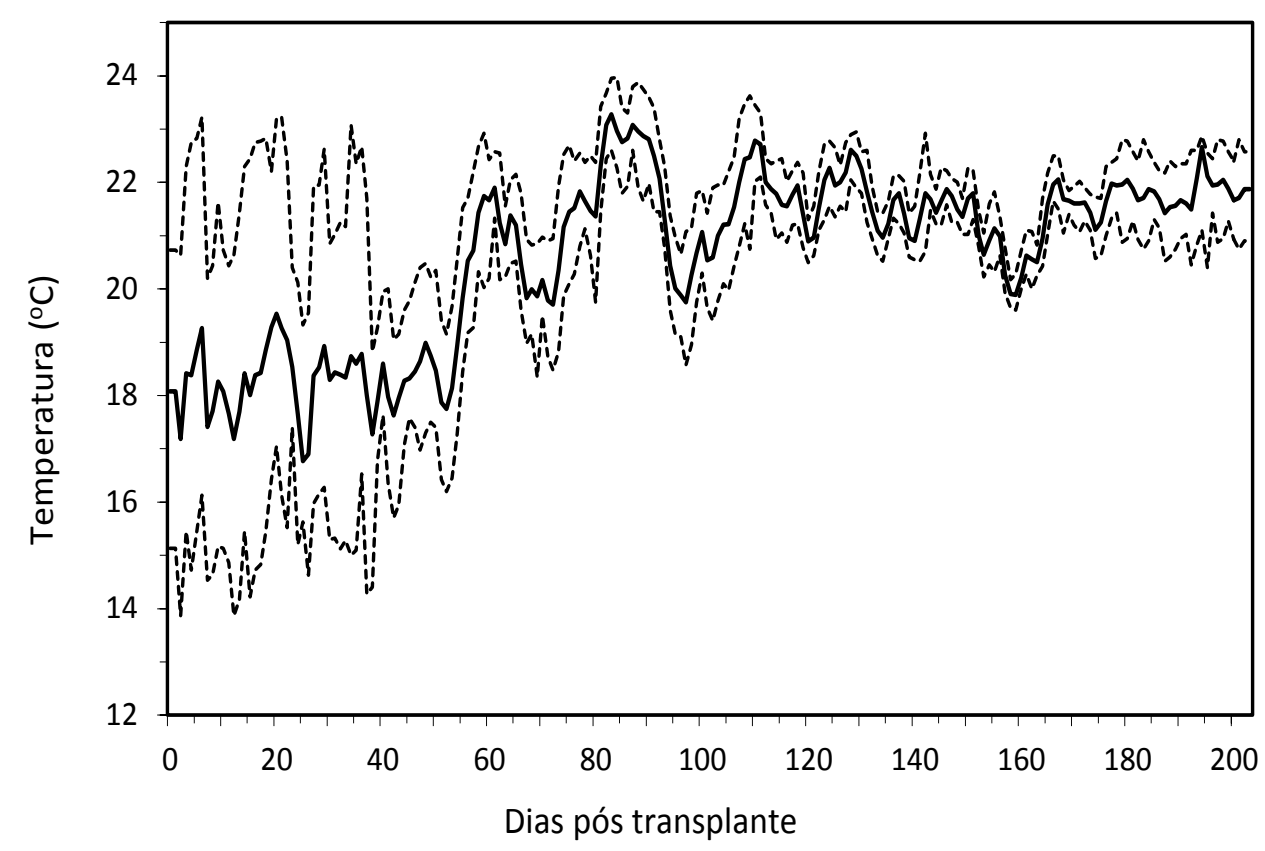

Figura 2.2 - Temperatura máxima, média e mínima diária do ar ao longo do ciclo de cultivo da berinjela, avaliada a 0,30 $\mathrm{m}$ de altura junto às plantas.

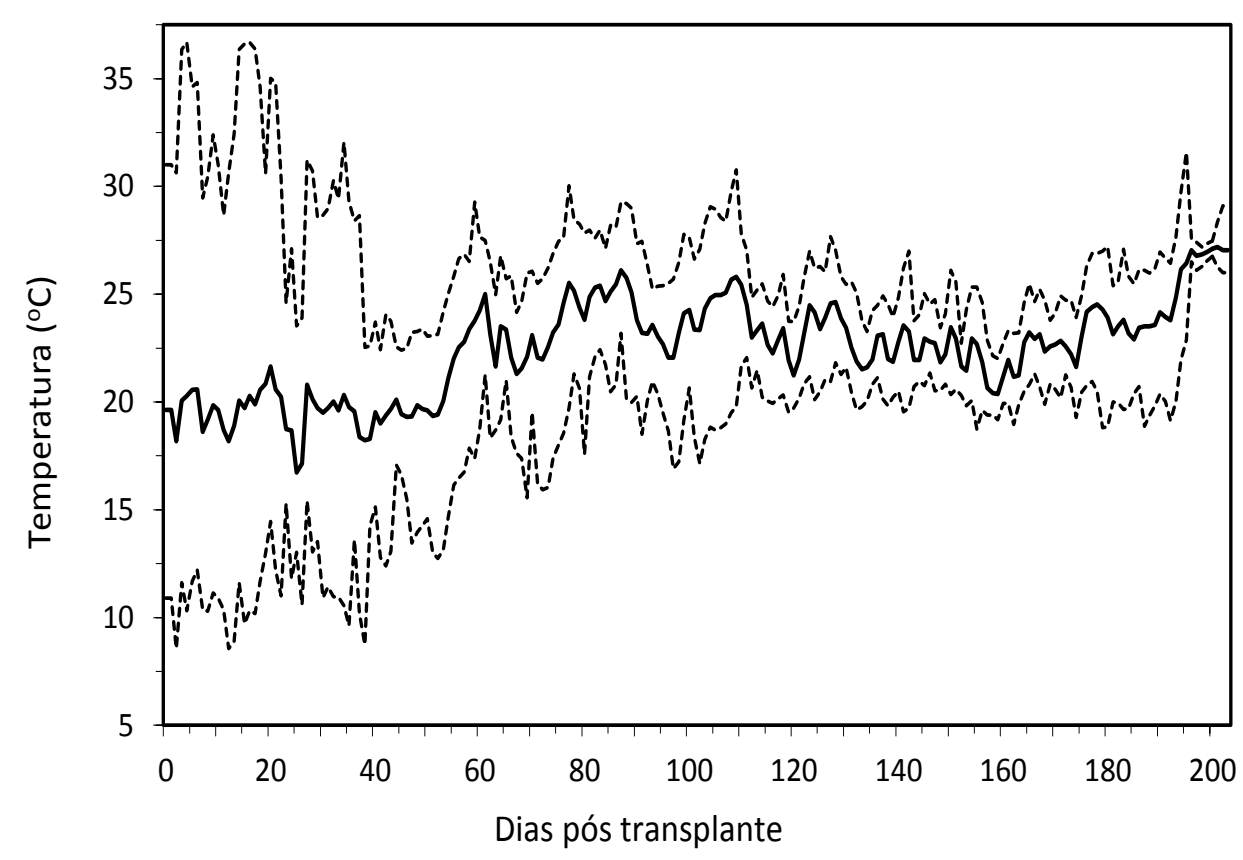


Figura 2.3 - Umidade relativa máxima, média e mínima diária do ar ao longo do ciclo de cultivo da berinjela, avaliada a 0,30 m de altura junto às plantas.

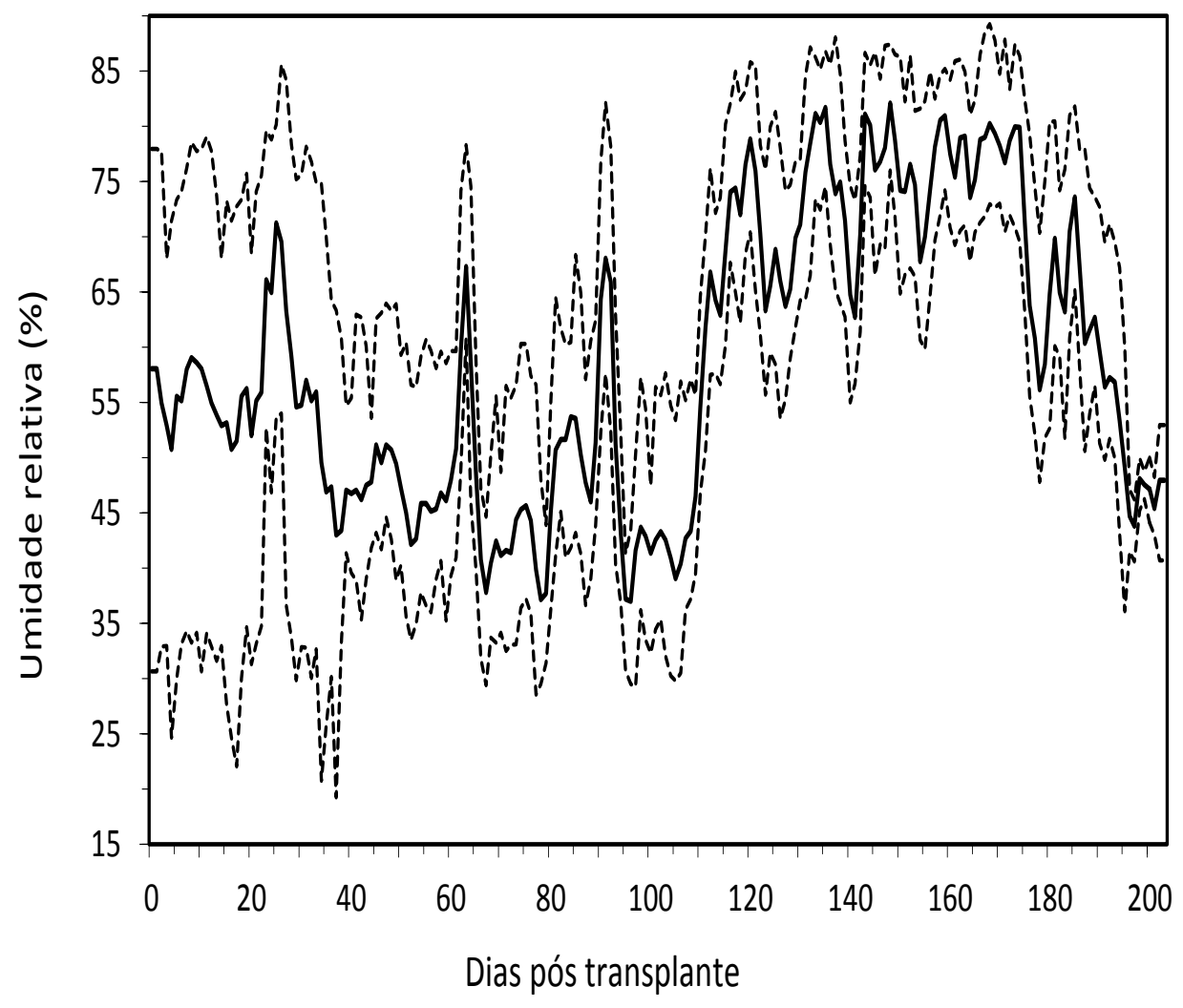

